\title{
Ghana: Combined First and Second Reviews Under the Arrangement Under the Extended Credit Facility, Request for Waiver of Nonobservance of Performance Criteria, Modification of Performance Criteria and Rephasing of Disbursements-Staff Report; Staff Statement and Supplement; Press Release on the Executive Board Discussion; and Statement by the Executive Director for Ghana.
}

In the context of the combined first and second reviews under the arrangement under the extended credit facility, request for waiver of nonobservance of performance criteria, modification of performance criteria and rephasing of disbursements, the following documents have been released and are included in this package:

- $\quad$ The staff report for the Combined First and Second Reviews Under the Arrangement Under the Extended Credit Facility, Request for Waiver of Nonobservance of performance Criteria, Modification of Performance Criteria and Rephasing of Disbursements, prepared by a staff team of the IMF, following discussions that ended on March 26, 2010, with the officials of Ghana on economic developments and policies. Based on information available at the time of these discussions, the staff report was completed on May 14, 2010. The views expressed in the staff report are those of the staff team and do not necessarily reflect the views of the Executive Board of the IMF.

- A staff statement of June 4, 2010 and staff supplement of June 8, 2010 updating information on recent developments.

- $\quad$ A Press Release summarizing the views of the Executive Board as expressed during its June 9, 2010 discussion of the staff report that completed the request and/or review.

- A statement by the Executive Director for Ghana.

The documents listed below have been or will be separately released.

Letter of Intent sent to the IMF by the authorities of Ghana*

Memorandum of Economic and Financial Policies by the authorities of Ghana*

Technical Memorandum of Understanding*

*Also included in Staff Report

The policy of publication of staff reports and other documents allows for the deletion of market-sensitive information.

\author{
Copies of this report are available to the public from \\ International Monetary Fund • Publication Services \\ $70019^{\text {th }}$ Street, N.W. • Washington, D.C. 20431 \\ Telephone: (202) 623-7430 • Telefax: (202) 623-7201 \\ E-mail: publications@imf.org Internet: http://www.imf.org
}

\author{
International Monetary Fund \\ Washington, D.C.
}


INTERNATIONAL MONETARY FUND

GHANA

\section{Combined First and Second Reviews Under the Arrangement Under the Extended Credit Facility, Request for Waiver of Nonobservance of Performance Criteria, Modification of Performance Criteria and Rephasing of Disbursements}

Prepared by the African Department

(In consultation with other departments)

Approved by Michael Atingi-Ego and Dominique Desruelle

May 14, 2010

$\begin{array}{ll}\text { ECF } & \text { The Executive Board approved Ghana's three-year ECF arrangement on } \\ \text { arrangement: } & \text { July 15, 2009, with access of SDR } 387.45 \text { million (105 percent of quota). } \\ \text { Results of the } & \text { All quantitative performance criteria were met through end-2009 except the } \\ \text { first and } & \text { end-September ceiling on the overall fiscal balance and the continuous } \\ \text { second } & \text { limit on non-concessional external debt, which was breached in November. } \\ \text { reviews: } & \text { Two structural benchmarks missed at end-September will be met by July- } \\ & \text { September 2010; four benchmarks for end-December 2009 were met, some } \\ \text { ahead of schedule. Notwithstanding a weaker fiscal outturn than }\end{array}$




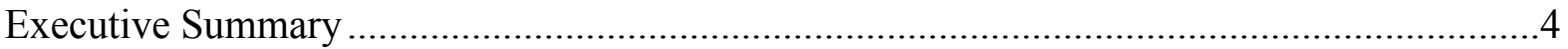

I. Recent Developments and Program Performance ..............................................................

II. Macroeconomic Framework for 2010 and the Medium Term ............................................

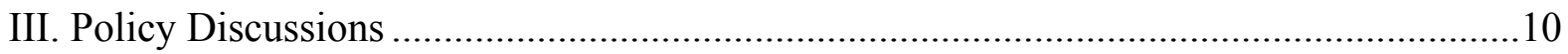

A. Reducing the Fiscal Deficit............................................................................10

B. Progress Toward Debt Sustainability ………………..........................................12

C. Structural Fiscal Reforms ..............................................................................

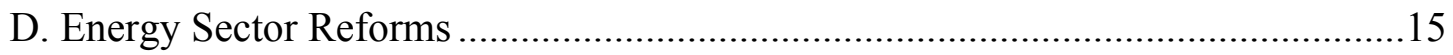

E. Monetary and Exchange Rate Policies ................................................................15

F. Maintaining Financial Sector Stability ...................................................................16

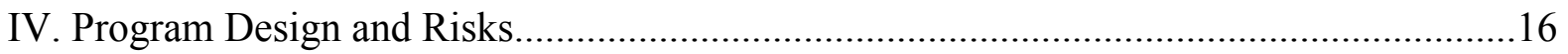

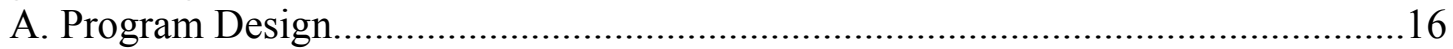

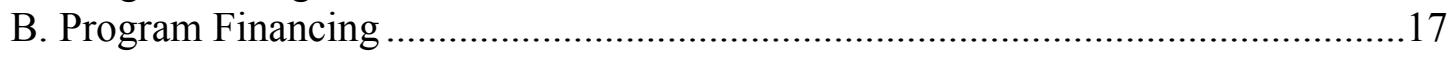

C. Program Risks and Mitigation...............................................................................17

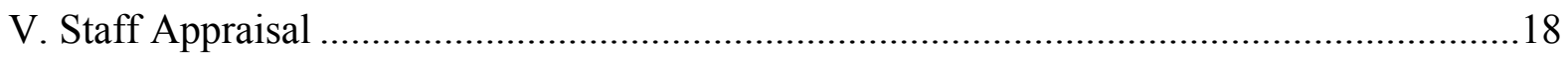

Boxes

1. Poverty Reduction Strategy for 2010-13 …….......................................................12

2. $\quad$ Framework for Managing Oil and Gas Revenues....................................................14

Figures

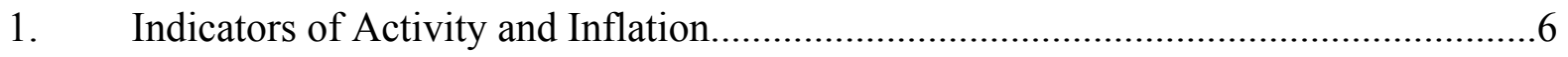

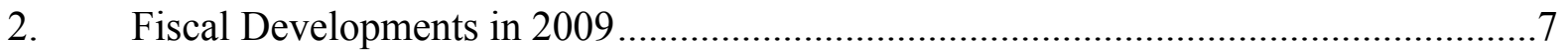

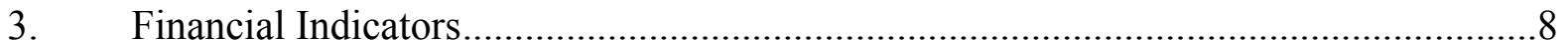

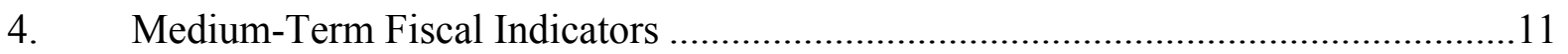

Tables

1. Selected Economic and Financial Indicators, 2007-13 …….....................................20

2. Summary of Central Government Budgetary Operations, 2007-13 …........................21

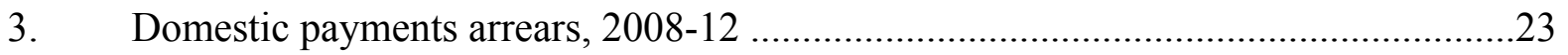

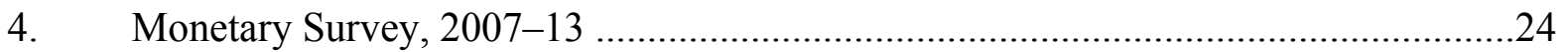

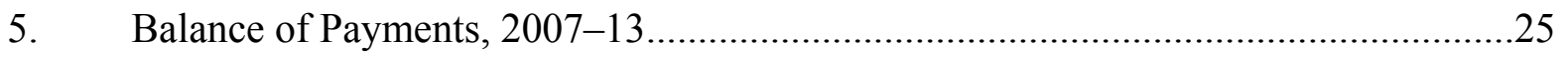

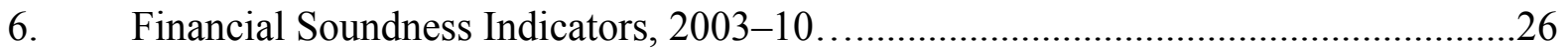

7. External Financing Requirements and Sources, 2006-14 ……...............................27

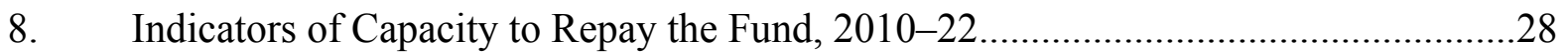




\section{Appendices}

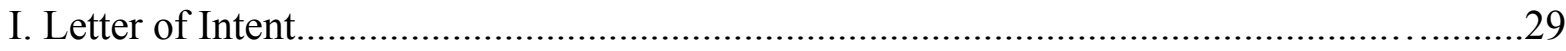

Attachment I. Memorandum of Economic and Financial Policies, 2010-12.............31

Attachment II. Technical Memorandum of Understanding....................................51

II. Updated Debt Sustainability Analysis..........................................6 62 


\section{EXECUTIVE SUMMARY}

Ghana's economy has been cushioned from the worst effects of the global recession. After 7.3 percent expansion in 2008, growth was an estimated 3-4 percent in 2009, benefiting from strong commodity exports and favorable rainfalls. Growth is projected to firm to 4-5 percent in 2010, ahead of a sharp rise in 2011 with the start of oil production.

More restrictive policies have reduced domestic and external imbalances. Inflation fell to 11.7 percent in April 2010, from a peak of over 20 percent in June 2009. Prospects look good for single digit inflation by end-2010, though it will be important to avoid premature monetary easing. The current account deficit has narrowed, the currency has appreciated modestly since July 2009, and gross reserve cover increased to nearly 3 months of imports at end-2009.

Fiscal performance fell substantially short of program goals in 2009. Although the end-year fiscal deficit met the cash-basis performance criterion and was substantially lowerthan in 2008, the deficit on a commitment basis was about 3 percentage points of GDP larger than programmed, financed by new domestic expenditure arrears. Other quantitative targets under the ECF arrangement were met through end-2009, except the end-September ceiling on the overall fiscal deficit and the limit on nonconcessional external debt.

Discussions focused on the appropriate fiscal stance for 2010. The program's original goal to limit the fiscal deficit to 6 percent of GDP is now unattainable, given trends in tax performance and interest costs. The revised program targets a fiscal deficit of 8 percent of GDP in 2010, with further reductions in 2011-12. A new program ceiling will prevent recourse to domestic expenditure arrears.

Generally good progress has been made in reinvigorating structural reforms. After two structural benchmarks for end-September were missed (rescheduled for July-September 2010), all four structural benchmarks for end-December 2009 were met, some in advance.

Program risks center on budget implementation. A number of revenues are subject to downside risks, while some areas of spending, notably public administration, have seen over-runs in the past. The authorities' commitment to limiting new energy subsidies and readiness to implement fiscal contingency plans, if needed, will be key. As projected oil revenues will create little new fiscal space in 2011-12, it will be important to manage expectations about the short-term oil "dividend". 


\section{Recent Developments and Program Performance ${ }^{1}$}

1. Ghana's growth of 3-4 percent in 2009 was about twice the estimated average for sub-Saharan Africa. Robust cocoa and gold export prices and beneficial rainfalls helped cushion against the effects of tighter policies and lower remittances (Figure 1 and Table 1). ${ }^{2}$ With slower growth and modest currency appreciation since mid-2009, inflation has remained within the inner consultation band under the program.

\section{Fiscal performance in $\mathbf{2 0 0 9}$ was weaker than programmed, giving rise to} substantial new domestic expenditure arrears. Domestic revenues were $1 \frac{1}{2}$ percent of GDP lower than budgeted on account of weak trade-related tax collections (Figure 2). Grant receipts also fell short by about 1 percent of GDP. Some expenditures also exceeded budgeted levels, notably the wage and salary bill (in part due to payment of retroactive claims) and domestic interest costs. The fiscal deficit and net domestic financing at year-end were kept within program ceilings ${ }^{3}$ by deferring revenue transfers to statutory funds (2.4 percent of GDP) and by incurring new arrears to domestic suppliers (1.8 percent of GDP). The budget deficit on a commitment basis was an estimated 3 percentage points of GDP above the program goal, albeit significantly down from 2008 (Text Table 1, and Tables 2a, 2b, and 3).

Text Table 1. 2009 Fiscal Consolidation

\begin{tabular}{lcccr}
\hline & 2007 & 2008 & \multicolumn{2}{c}{2009} \\
\cline { 5 - 6 } & Est. & Est. & Prog. & Prov. \\
\hline & & & & \\
Primary balance & -6.1 & -10.7 & -5.1 & -5.0 \\
Budget balance (cash-based) & -9.2 & -14.5 & -9.4 & -9.7 \\
Budget balance (commitment-based) & -9.7 & -20.1 & -7.8 & -11.0 \\
\hline
\end{tabular}

Sources: Official data, and IMF staff estimates.

3. The Bank of Ghana (BoG) eased monetary conditions as inflationary pressures receded (Table 4 and Figure 3). The policy rate was lowered from a peak of 18.5 percent in 2009 to 15 percent by April 2010. Capital inflows at end-2009 partly increased liquidity, leading to a marked decline in interbank and Treasury bill rates in early 2010 . The September and December indicative ceilings on BoG net domestic assets under the program were met.

\footnotetext{
${ }^{1}$ Program performance is summarized in Table 1 of the authorities' Letter of Intent (MEFP).

${ }^{2}$ Real sector data is generally weak. Important gains are planned by mid-2010, including rebasing the national accounts on 2006 (rather than 1993) weights and producing quarterly national accounts.

${ }^{3}$ The adjusted end-September deficit ceiling was missed by GH $\notin 170$ million ( 0.8 percent of GDP).
} 
Figure 1. Ghana: Indicators of Activity and Inflation
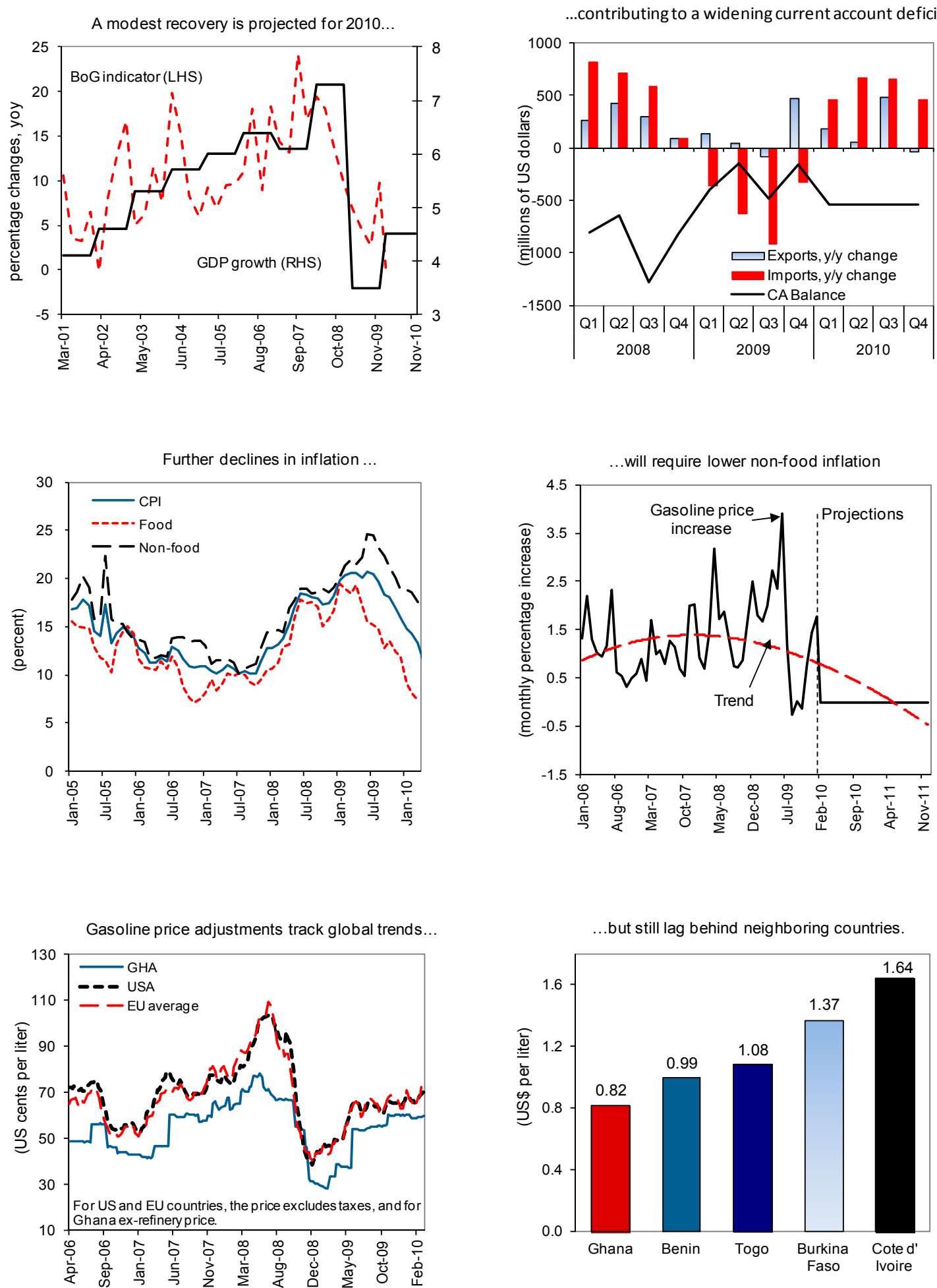

Sources: Ghanaian authorities; and IMF staff estimates and projections. 
Figure 2. Ghana: Fiscal Developments in 2009

Total revenues were below targets...

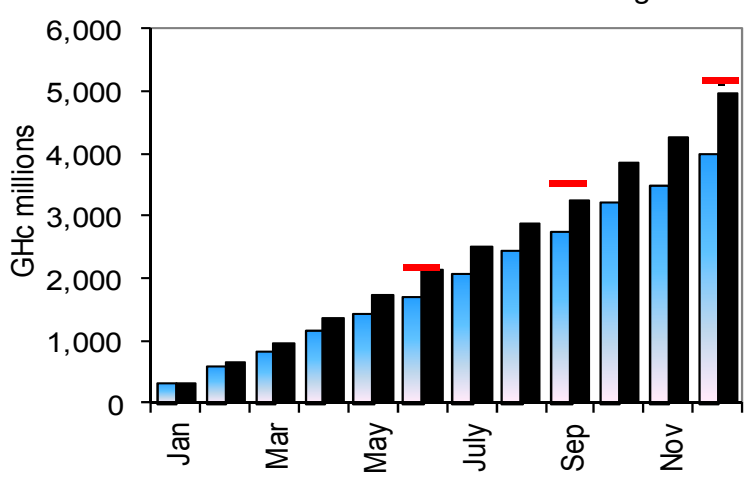

Restrained non-interest expenditures... ${ }^{1}$

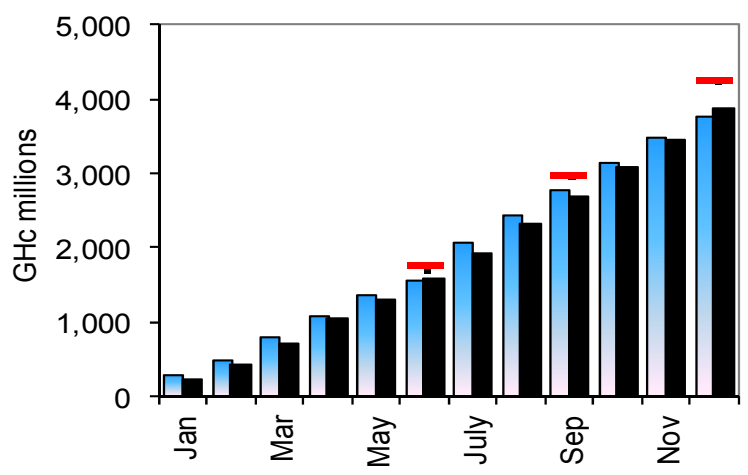

The budget deficit was slightly below target..

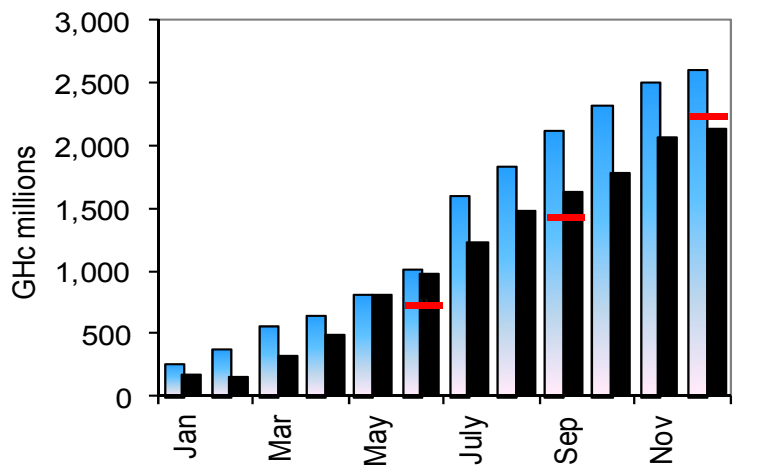

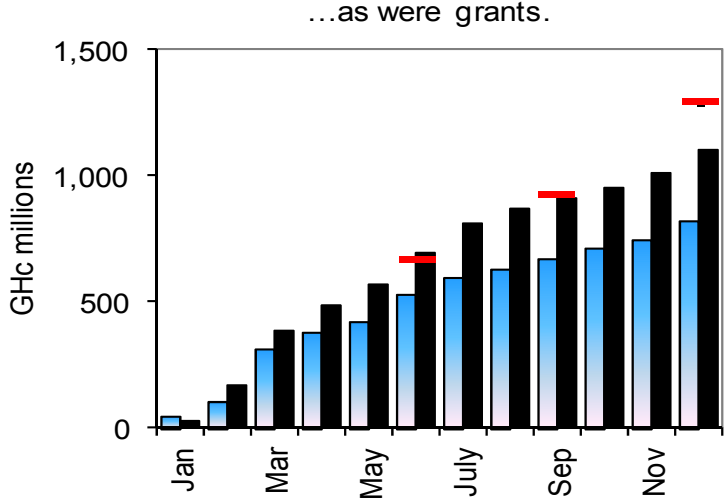

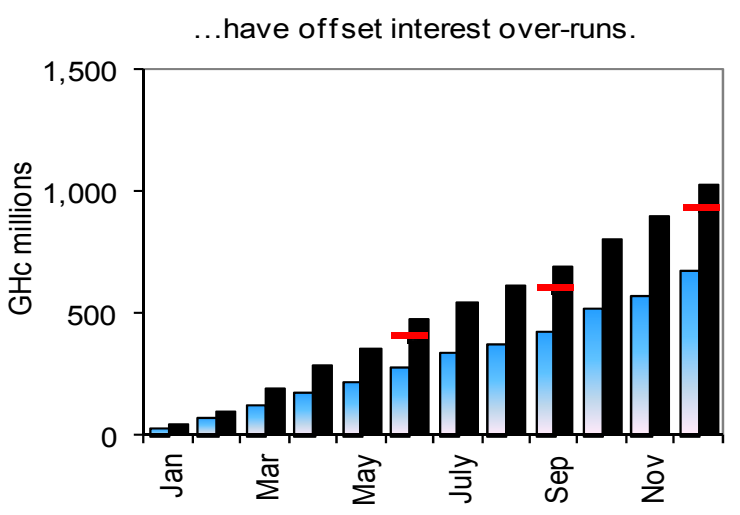

... and domestic financing was on track.

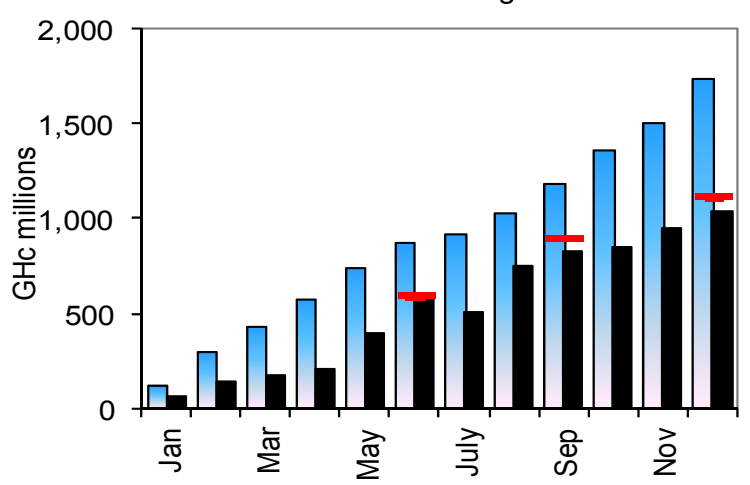

口2008 $2009 \quad-2009$ Projection (June) and Adjusted Program Targets (Sept. \& Dec.)

1 Including arrears clearance and VAT refunds.

Sources: Ghanaian authorities; and IMF staff estimates. 
Figure 3. Ghana: Financial Indicators
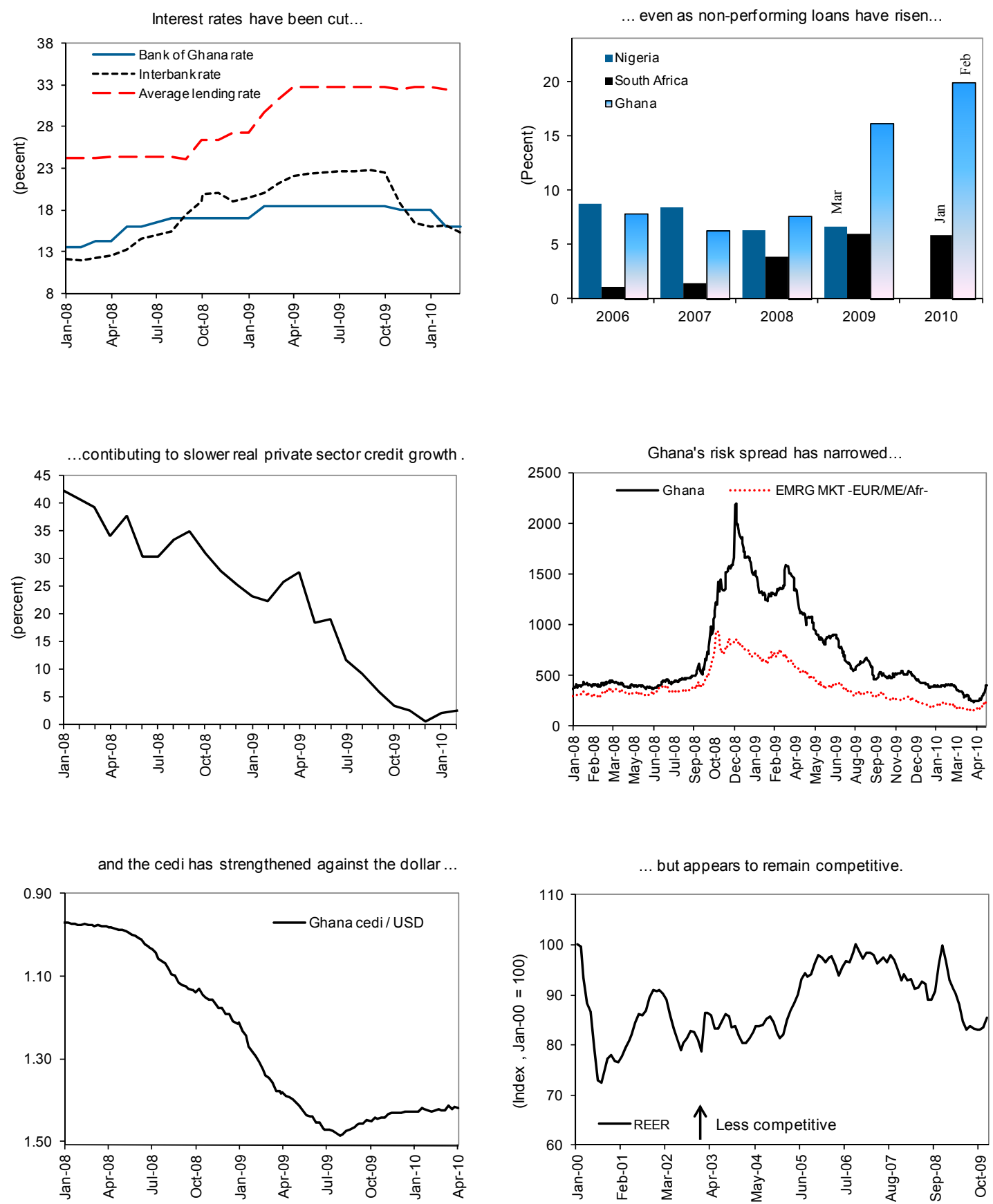

Sources: Ghanaian authorities; and IMF staff estimates. 
4. External performance improved substantially during 2009. Strong exports and falling imports narrowed Ghana's current account deficit from 18.7 percent of GDP in 2008 to 5.1 percent of GDP in 2009 (Table 5). Gross reserves at end-2009 reached 2.9 months of import cover, benefitting from the SDR allocations ( $\$ 450$ million) in 2009 and capital inflows by banks to meet higher statutory minimum capital levels. The program floor on net international reserves was exceeded by a substantial margin.

\section{Progress in reinvigorating structural reforms gained momentum through} end-2009 (MEFP Table 3). Two September structural benchmarks were missed: progress stalled in computerizing subvented agencies' payrolls, largely reflecting inadequate funding for software and consultants, and a full review of tax exemptions and waivers was delayed due to capacity constraints. With adequate resourcing for these projects, the authorities intend to meet the benchmarks by July-September 2010. ${ }^{4}$ All four December 2009 benchmarks were met, some ahead of schedule.

\section{MACROECONOMIC FRAMEWORK FOR 2010 AND THE MEDIUM TERM}

6. Growth is projected to strengthen to 4-5 percent in 2010. This reflects the continued strength of commodity exports and new oil-related investments. With the move to oil production in 2011, real GDP is projected to rise by about 20 percent, subsequently easing to about 6 percent. The BoG targets a decline in inflation to high single digit levels by end-2010. The external current account deficit is projected to widen in 2010 on account of oil-related capital goods imports, subsequently narrowing as oil exports start (Text Table 2).

Text Table 2. Medium-Term Macroeconomic Framework, 2008-14

\begin{tabular}{lrrrrrrr}
\hline & 2008 & 2009 & 2010 & 2011 & 2012 & 2013 & 2014 \\
& & Est. & Prog. & Proj. & Proj. & Proj. & Proj. \\
\hline & \multicolumn{7}{c}{ (Annual percentage changes, unless otherwise indicated) } \\
Real GDP & 7.3 & 3.5 & 4.5 & 20.1 & 6.8 & 5.3 & 5.0 \\
Non-oil real GDP & 7.3 & 3.5 & 4.5 & 5.6 & 6.0 & 6.0 & 5.7 \\
Inflation, end-of-period & 18.1 & 16.0 & 9.5 & 8.5 & 5.0 & 5.0 & 5.0 \\
Current account balance (percent of GDP) & -18.7 & -5.1 & -12.1 & -8.1 & -7.5 & -7.8 & -5.1 \\
Gross reserves (months of imports) & 2.3 & 2.9 & 2.9 & 3.6 & 4.2 & 5.1 & 5.7 \\
\hline
\end{tabular}

Sources: Official data and IMF staff estimates and projections.

\footnotetext{
${ }^{4}$ Contrary to earlier plans, the security agencies will not be migrated to the centralized personnel and payroll management system. Staff agreed with this approach, based on the authorities' indication that existing computerized systems at these agencies are sufficient.
} 


\section{Policy Discussions}

\section{A. Reducing the Fiscal Deficit}

\section{For 2010, the authorities are targeting a budget deficit of 8 percent of GDP.}

This upward revision from the original program target of 6 percent of GDP reflects a less favorable outlook for tax revenues as well as upward revisions to domestic interest expenditures. Nevertheless, the fiscal effort remains ambitious, with the deficit declining by an estimated $3 \frac{1}{2}$ percentage points of GDP on a commitment basis (Text Table 3 ). The authorities aim to reduce the budget deficit to less than 4 percent of GDP from 2012, reversing the rising trend in the ratio of public debt to GDP (Section III.B and Figure 4).

Text Table 3. Fiscal Outlook, 2009-13

\begin{tabular}{|c|c|c|c|c|c|c|}
\hline & \multirow{2}{*}{$\begin{array}{l}2009 \\
\text { Prov. }\end{array}$} & \multicolumn{2}{|c|}{2010} & \multirow{2}{*}{$\begin{array}{l}2011 \\
\text { Proj. }\end{array}$} & \multirow{2}{*}{$\frac{2012}{\text { Proj. }}$} & \multirow{2}{*}{$\frac{2013}{\text { Proj. }}$} \\
\hline & & $\begin{array}{l}\text { ECF } \\
7 / 09 \\
\end{array}$ & $\begin{array}{r}\text { Rev. } \\
\text { Prog. }\end{array}$ & & & \\
\hline & \multicolumn{6}{|c|}{ (Percent of nonoil GDP) } \\
\hline Primary fiscal balance & -5.0 & -5.7 & -2.9 & 0.1 & 0.3 & -0.3 \\
\hline Overall fiscal balance (cash-based) & -9.7 & -6.0 & -8.0 & -4.5 & -3.5 & -3.5 \\
\hline Overall fiscal balance (commitment-based) & -11.0 & -6.1 & -7.6 & -2.5 & -1.9 & -3.5 \\
\hline Non-oil fiscal balance (cash-based) /1 & -9.7 & -6.0 & -8.0 & -9.9 & -8.9 & -8.5 \\
\hline Public debt & 60.2 & 66.6 & 64.9 & 62.0 & 59.1 & 58.4 \\
\hline \multirow[t]{2}{*}{ Oil revenues } & $\cdots$ &. & $\ldots$ & 5.4 & 5.4 & 5.0 \\
\hline & \multicolumn{6}{|c|}{ (Percent of oil revenues) } \\
\hline Projected spending of oil revenues & $\cdots$ & $\ldots$ & $\ldots$ & 9.4 & 34.2 & 82.9 \\
\hline
\end{tabular}

Sources: Official data, and IMF staff estimates and projections.

1/Excludes oil revenues.

\section{Projected fiscal consolidation in 2010 reflects a 3 $1 \frac{1}{2}$ percentage point of GDP} increase in revenues. Tax policy changes include a rise in mining royalties from 3 to 5 percent, a shift from specific to ad-valorem taxes on tobacco and drinks, higher fees and charges, and a restoration of import duties on food products that were eliminated in 2008. The authorities also project an increase in capital gains taxes and transfers from the Ghana Cocoa Board and Bank of Ghana (MEFP q19).

9. Expenditures are restrained in 2010. On a commitment basis, projected spending is broadly unchanged from 2009 levels, and about 9 percentage points of GDP below 2008. Areas of spending pressure, relative to the original program, are interest payments and the public wage bill, with the latter reflecting a higher than projected 2009 outturn and the move to a new unified public pay structure. Power subsidies will be reduced by the planned hike in electricity tariffs (para. 19). Consistent with the government's new poverty reduction strategy (Box 1), pro-poor spending is being protected during the 2010 fiscal consolidation, 
Figure 4. Ghana: Medium-Term Fiscal Indicators

Revenues from oil..

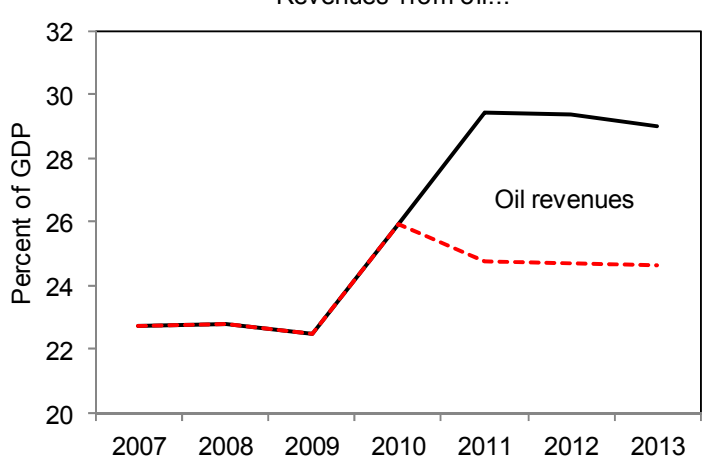

Total revenue $\quad-$ - - Total revenue (excl. oil)

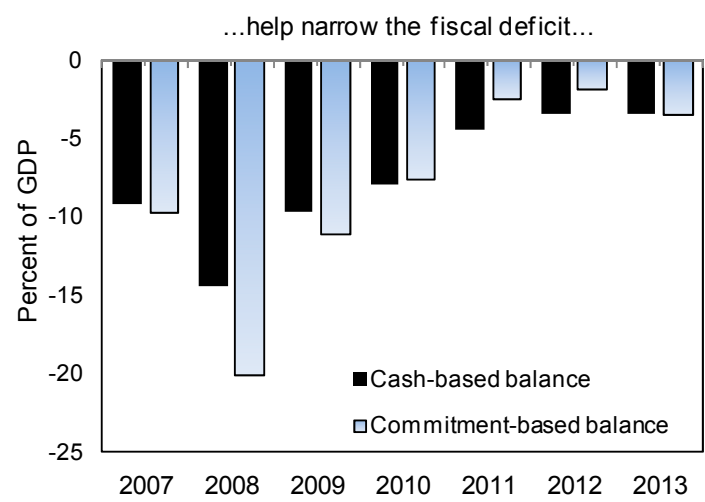

With declines in public debt.

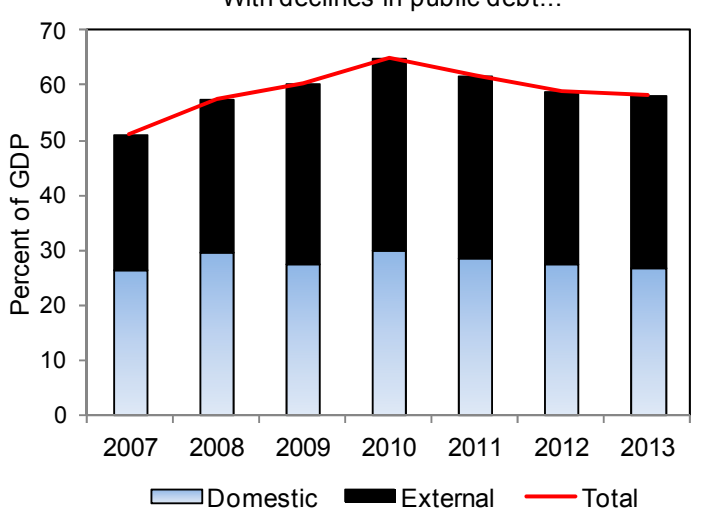

..combined with expenditure restraint...

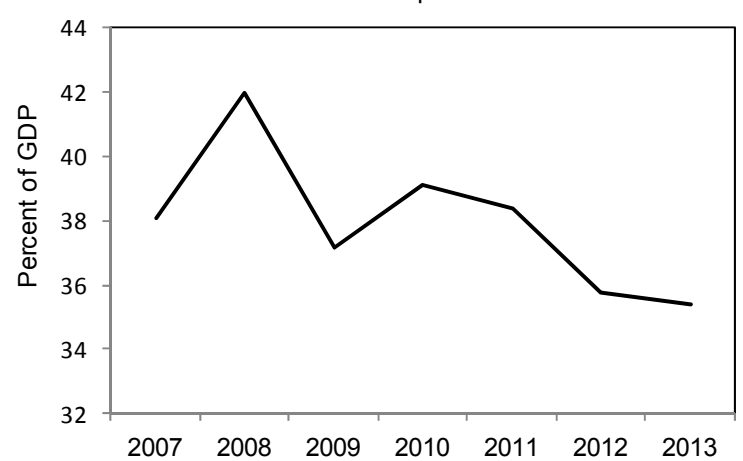

— Total expenditure (inc. domestic arrear repayments)
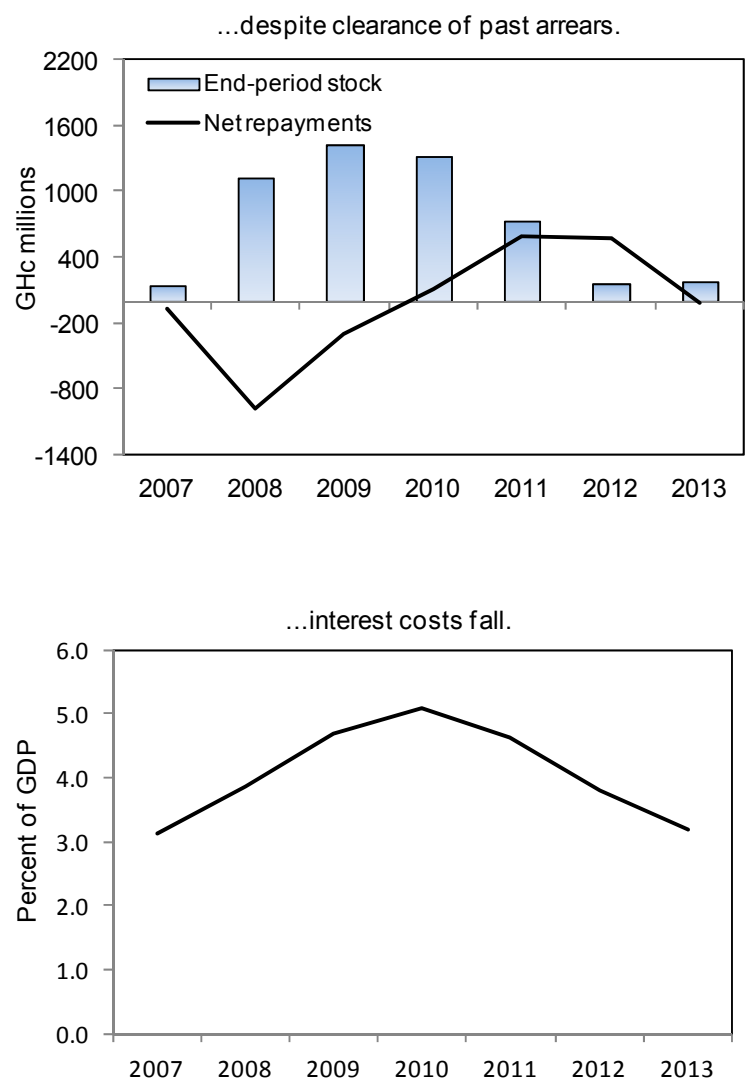

Sources: Ghanaian authorities; and IMF staff estimates and projections. 
remaining at 8.4 percent of GDP in line with the estimated 2009 outcome, rising to 9.1 percent of GDP in 2011-12.

\section{Box 1. Poverty Reduction Strategy for 2010-13}

An updated Poverty Reduction Strategy for 2010-13, the Ghana Shared Growth and Development Agenda (GSDA), will be submitted to parliament by end-August 2010 after consultations with key stakeholders. Key elements are:

- Macroeconomic stability. Policies will target fiscal consolidation to reduce public debt vulnerability, annual average real growth of about 7 percent, low inflation, and exchange rate stability.

- $\quad$ Enhanced private sector competitiveness. Policies will remove regulatory and institutional constraints that hamper private sector competitiveness and promote public-private partnerships.

- $\quad$ Sectoral priorities. To attain the Millennium Development Goals, the GSDA focuses on agricultural reforms, human development, water and sanitation, transportation, ICT, and energy.

- $\quad$ Transparent and accountable governance. The GSDA seeks to strengthen governance institutions, public policy management, and the role of civil society organizations.

10. Looking ahead, Ghana's oil "dividend" will initially be modest. The mediumterm fiscal framework (Text Table 3) suggests that only around one-third of projected oil revenues of 5 $\frac{1}{2}$ percent of GDP could be spent on new programs in 2011-12 without jeopardizing the planned fiscal consolidation. The available fiscal space would increase significantly in 2013 , as arrears repayments come to an end.

\section{B. Progress Toward Debt Sustainability}

\section{On current projections, public debt peaks at 65 percent of GDP at end-2010.}

This increase of more than 20 percentage points of GDP in just four years excludes domestic expenditure arrears projected at 5 percent of GDP and state-owned enterprise (SOE) liabilities to banks from past underpricing of energy products amounting to about 6 percentage points of GDP.

\section{A timeline has been agreed for repaying domestic expenditure arrears}

(MEFP q22-23, and Table 3). After an independent audit, arrears repayments in 2009 and 
early 2010 focused on road and other contractors, where unpaid bills had impacted the banking sector and brought projects to a standstill. Overdue transfers to governmental trust funds will be settled in 2011-12.

13. Options for clearing SOE debts are being examined. In early-2010, new public debt was issued to clear about one-third of the oil refinery's delinquent debts to the Ghana Commercial Bank, equivalent to 1.7 percent of GDP. ${ }^{5}$ Options for clearing the remaining delinquent bank debts of the refinery and the public electricity company, amounting to about 6 percent of GDP, are being examined based on advice from an MCM technical assistance mission in April-May 2010. This would likely require new public debt issuance, increasing the debt ratio above levels in the current medium-term fiscal framework. While the resulting debt service burden would be manageable, it would further reduce the fiscal space associated with the move to oil producer status.

\section{Given Ghana's increased debt vulnerability, debt management is being} strengthened (MEFP $\mid 40-41$ ). A debt management strategy is being developed drawing on joint Bank-Fund technical assistance, and projects for nonconcessional financing will be selected based on clearly established guidelines (both structural benchmarks for December 2010). The continuous program limit on contracting or guaranteeing new external nonconcessional debt was breached when the government in November took over \$100 million of liabilities of the Ghana National Petroleum Corporation (GNPC; MEFP q8). To avoid a recurrence, new structural benchmarks (MEFP Table 3) have been included in the program and the government has reinforced requirements that the Ministry of Finance's Debt Management Division monitor all public debt contracts to verify compliance with the agreed debt limits (MEFP $\mid 41)$.

\section{New nonconcessional borrowing will be contracted, consistent with debt} sustainability. The original program provision for commercial borrowing of up to \$300 million by GNPC has not been used, and the authorities have requested it be scaled back to \$200 million. Instead, cost-benefit analysis supports the use of nonconcessional financing for the purchase of firefighting equipment (\$49.1 million) and a coastal protection scheme ( $\$ 100$ million). Consistent with the new guidelines on debt limits, the program provides for further nonconcessional borrowing of up to $\$ 200$ million. Including such borrowing, the updated debt sustainability assessment (Appendix II) indicates that Ghana would remain at moderate risk of debt distress, albeit with some increase in debt vulnerabilities.

\footnotetext{
${ }^{5}$ This payment adds to the public sector borrowing requirement, but is recorded "below the line" as state enterprise recapitalization, rather than adding to the fiscal deficit.
} 


\section{Structural Fiscal Reforms}

\section{Steps have been taken toward more robust revenue administration}

(MEFP -28-29). Reforms center on the recent establishment of an integrated Ghana

Revenue Authority (GRA), supported by FAD technical assistance and development partner financing. Tax policy reforms include an increase in the VAT threshold to bring Ghana into line with international best practice (December 2010 benchmark) and adoption of a tax regime for small businesses (June 2011 benchmark) (MEFP $\$ 26-27)$.

\section{A new approach is being taken toward budget management (MEFP $₫ 30-35$ ).}

Interim efforts to strengthen cash management are being succeeded by steps to streamline and bring a more strategic focus to budget preparation (by March 2011), drawing on FAD advice. A strategy for updating Ghana's Integrated Financial Management Information System has been adopted (December 2009 benchmark), and the new system will be rolled out to pilot sites by March 2011 (program benchmark). A framework for managing oil and gas revenues is being finalized (Box 2).

\section{Box 2. Framework for Managing Oil and Gas Revenues}

A comprehensive framework is planned for managing oil and gas revenues. Public consultations on the proposed framework were conducted in February-April 2010, and a draft bill is to be submitted to parliament in May-June. Fund staff support the thrust of the proposed model, which is in line with international best practice.

A high degree of transparency is envisaged. Oil and gas revenues would be collected by the Ghana Revenue Authority and credited to a dedicated petroleum account at the Bank of Ghana. Revenue data would be published quarterly and the Minister of Finance would report annually to parliament on petroleum-related transactions. Annual audits would be prepared either by the Auditor-General or an internationally reputable auditor.

A rules-based approach for allocating revenues is planned. Under the current draft, spending of oil revenues would reflect either benchmark revenues (calculated using the 5-year moving average of oil prices and production volumes) or the estimated sustainable income (ESI), a permanent income-based measure of oil wealth. This approach would ensure that a significant portion of revenues is available to finance (i) a stabilization fund to smooth spending in the face of price or production shocks, and (ii) a future generations fund. Balances in the funds would be largely invested abroad.

18. Public administration reform remains a priority. The authorities' strategy focuses on removing absentee workers from the public payroll, an approach successfully piloted in the health service; computerizing subvented agency payrolls to provide better headcount information; identifying agencies to be commercialized or liquidated (benchmark for 
end-2010); and conducting a survey of pay comparability ahead of future public pay rounds (benchmark for June 2011) (MEFP \$36-37).

\section{Energy Sector Reforms}

19. Restructuring plans are being adopted for the electricity sector and oil refinery. Electricity sector SOEs will be recapitalized under a plan supported by the World Bank, supported by a 33 percent increase in power tariffs (prior action for the first and second ECF reviews). If the new tariffs, combined with improved collections and productivity gains, do not result in full cost recovery, a further tariff increase to close any remaining gap would be implemented by the third ECF review (MEFP 938). For the Tema Oil Refinery (TOR), the authorities are clearing its bank debts (para. 13) and are seeking World Bank support to develop a comprehensive restructuring plan (MEFP q39).

\section{Commodities hedging is being considered to help smooth petroleum product}

prices. Consideration is being given to a levy on petroleum products to finance the purchase of call options on oil prices. Should oil prices rise sharply, the options would yield a profit that could provide the financing to potentially avoid a temporary rise in product prices, or to phase in a sustained increase in prices more slowly. Staff noted that management of the scheme should be subject to clear guidelines to limit risk, and underlined that hedging would not eliminate the need for full pass through of sustained changes in global prices.

\section{E. Monetary and Exchange Rate Policies}

21. A high single-digit inflation target is set for end-2010 and 2011 (MEFP Table 2). The monetary easing since November 2009 appears consistent with the Bank of Ghana's inflation target. However, staff pointed to upside pressures from firming global oil prices and planned hikes in electricity tariffs. The authorities should stand ready to tighten policies, if needed, to avoid an upturn in inflation expectations. ${ }^{6}$

22. The BoG will maintain a flexible exchange rate regime. In the event of stronger than programmed external performance, it would allow some currency adjustment while also using the opportunity to further strengthen reserve cover (MEFP $\mid 43$ ).

23. Key recommendation of the 2009 safeguards assessment has been implemented. A new BoG Board was appointed in March 2010, ${ }^{7}$ and the authorities are committed to timely implementation of other safeguards assessment recommendations.

\footnotetext{
${ }^{6}$ The program target includes an adjuster to allow for the pass through of the first round impact of higher power tariffs (TMU $\$ 34)$.

${ }^{7}$ A legal challenge to the dismissal of the BoG Board in January 2009 caused a delay in nominating a successor Board. An advisory panel was established as an interim safeguards mechanism.
} 


\section{F. Maintaining Financial Sector Stability}

24. Three areas of financial sector vulnerability have emerged (MEFP $\$ 44-45)$. The majority state-owned Ghana Commercial Bank (GCB) has heavy loan concentration in the petroleum sector, largely reflecting loans to the loss-making state oil refinery (TOR).

Second, a smaller state-owned development bank became insolvent in 2009 as a result of mismanagement. The BoG has taken a majority stake in the latter, pending its restructuring for divestiture. Third, industry-wide nonperforming loans more than doubled to 20 percent of total loans in February 2010 (Table 6), reflecting the slowdown in economic growth, weaknesses in banks' risk management and losses by some energy sector SOEs.

25. A response to these risks has been developed. In response to a request from the authorities, a mission from MCM in April-May 2010 is reviewing the situation of GCB and the BoG-owned development bank and advising on options for clearing TOR's debts consistent with the government's medium-term debt strategy and macroeconomic program. It will also advise on the lessons for banking supervision and liquidity support operations. The BoG intends to continue to strengthen its supervisory capacity, with a focus on risk management aspects (MEFP $\mid 44)$. An FSAP update is envisaged for mid-2010.

\section{Program Design AND Risks}

\section{A. Program Design}

26. Quantitative targets through end-June 2011 are presented in Table 2 of the MEFP. Key changes in program design are to:

- External nonconcessional debt. Modifications to the ceilings are summarized in para. 15 .

- Domestic arrears. To avoid fiscal slippages financed by new domestic arrears, a program ceiling has been adopted.

- $\quad$ Poverty reducing spending. To protect poverty-reducing spending during the program period, an indicative floor has been adopted.

27. Structural benchmarks through end-June 2011 focus on revenue administration, public expenditure management, public debt management, pay and payroll management, and cost-recovery energy pricing (MEFP Table 3). 


\section{B. Program Financing}

\section{To support Ghana's policy adjustment, financing of $\mathbf{\$ 5 0 0}$ million has been identified for 2010.}

- $\quad$ Exceptional fiscal financing of \$275 million is being provided in 2010. The majority represents new World Bank lending (\$250 million), with the remainder from other budget support partners. The authorities are requesting financing, over and above this amount, to accelerate the repayment of domestic arrears. In 2011, no further fiscal financing gap is projected, reflecting the start of revenues from oil production.

- $\quad$ Balance of payments financing of about $\$ 225$ million is provided under the ECF arrangement in 2010, declining to about $\$ 135$ million in 2011. A proposed change to the phasing of ECF disbursements would reduce the degree of front-loading (MEFP, Table 4), consistent with Ghana's stronger-than-programmed external performance and revised policy commitments. ${ }^{8}$

\section{Program Risks and Mitigation}

29. Shortfalls in fiscal consolidation are an important risk under the program. The components of the 2010 budget have been reviewed carefully by staff, and appear adequate to achieve the program goal. Nevertheless, the budget is heavily dependent on projected increases in capital gains taxes and transfers from the Bank of Ghana and Ghana Cocoa Board, which account for around two-thirds of the 2010 revenue improvement, relative to GDP. Also, expenditure over-runs have been a persistent challenge, especially in public administration. The authorities have underlined their readiness to further strengthen fiscal performance, if needed (MEFP q21).

30. Strong communication of the program remains critical. Popular expectations of stable energy product prices continue to pose a challenge for the budget, and efforts are needed to strengthen the principle of market-based pricing, supported by a safety net for the poorest. Equally, expectations regarding the oil dividend risk running ahead of Ghana's scope to expand public spending, given remaining fiscal imbalances.

\footnotetext{
${ }^{8}$ Projected gross reserve cover at end-2010 is 2.9 months of imports, compared to an originally programmed 2.0 months (before the SDR allocation; or 2.4 months, after the 2009 SDR allocation).
} 


\section{Staff Appraisal}

31. Ghana's ECF-supported program has delivered some important achievements in its first year. Tighter fiscal policies have reduced domestic and external imbalances. At the same time, with a decline in global risk aversion, and with Ghana on track for oil production in 2011, foreign demand has re-emerged for cedi bond issues, improving the financing outlook.

32. But Ghana has taken only a first step toward macroeconomic stability. The budget deficit remains high, and was financed in 2009 only with resort to new domestic arrears. Further, the debt outlook is clouded by the need to address state enterprise losses from past under-pricing of energy products. On monetary policy, credibility in the inflation targeting regime still needs to be built, and will require clear communications and a willingness to tighten policies, if needed.

33. The planned fiscal consolidation in $\mathbf{2 0 1 0}$ is welcome. It represents a sizeable decline in the deficit, especially on a commitment basis. However, debt ratios will increase further, and the bulk of expenditure arrears will be addressed only in 2011-12. Although the deficit target appears achievable on current policies, the government should be ready to adopt contingency measures, if needed. Cost recovery pricing for power and petroleum products will be critical to avoiding unbudgeted subsidies, and the cost of the new public pay structure should be within the budgeted wage bill. Revenue earmarking to finance specific programs should be revisited, given the inflexibility it introduces into the budget.

34. The implications for Ghana's oil "dividend" are sobering. To achieve the planned fiscal consolidation and reduce debt vulnerability, only a small part of oil revenues would initially be available to increase public spending.

35. Good progress has been made in launching structural fiscal reforms. The establishment of an integrated Ghana Revenue Authority marks an important step toward strengthened revenue administration. Equally, high-level leadership for the design of new budget procedures and re-launch of Ghana's financial management information system is welcome.

\section{Concerted efforts are needed to address the financial deterioration of several} state-owned enterprises. The contagion from the under-pricing of energy products is evident in the financial performance of the electricity companies and oil refinery. The impact on public indebtedness will become evident as these losses are resolved. Steps to avert a recurrence should involve not only cost-recovery pricing of energy products, but also strengthened SOE governance and greater operating independence. Consideration being given to the option of divesting some state owned enterprises is welcome. 
37. The deterioration in banking indicators is of concern. Plans to review with Fund support the situation at GCB and review the lessons for banking supervision and liquidity management are welcome. Efforts to strengthen risk management in the banking system will require parallel steps to address financial sector spillovers from expenditure arrears, underperforming SOEs, and governance shortcomings in some banks.

\section{Plans to use hedging to smooth petroleum product prices should be pursued} with caution. Close supervision and strong internal controls over trading activities will be important for risk management. Furthermore, hedging may lead to unrealistic expectations regarding the scope to avoid future price adjustments.

\section{Early completion of Ghana's updated poverty reduction strategy will be}

important. Limitations in the range and timeliness of macroeconomic statistics also remain a challenge for policy makers.

40. Based on Ghana's performance and the strength of the program, staff recommends completion of the first and second reviews under the ECF arrangement. Given steps taken to strengthen fiscal performance, including through new fiscal measures in 2010 and reforms to revenue administration, tax policy, and public expenditure management, staff supports the requested waiver on the nonobservance of the performance criterion on the overall fiscal balance at end-September 2009. Further, based on measures taken to strengthen debt management and to broaden the coverage of the debt limits to key SOEs, staff also supports the waiver on the nonobservance of the performance criterion on contracting or guaranteeing of external nonconcessional debt. 
Table 1. Ghana: Selected Economic and Financial Indicators, 2007-13

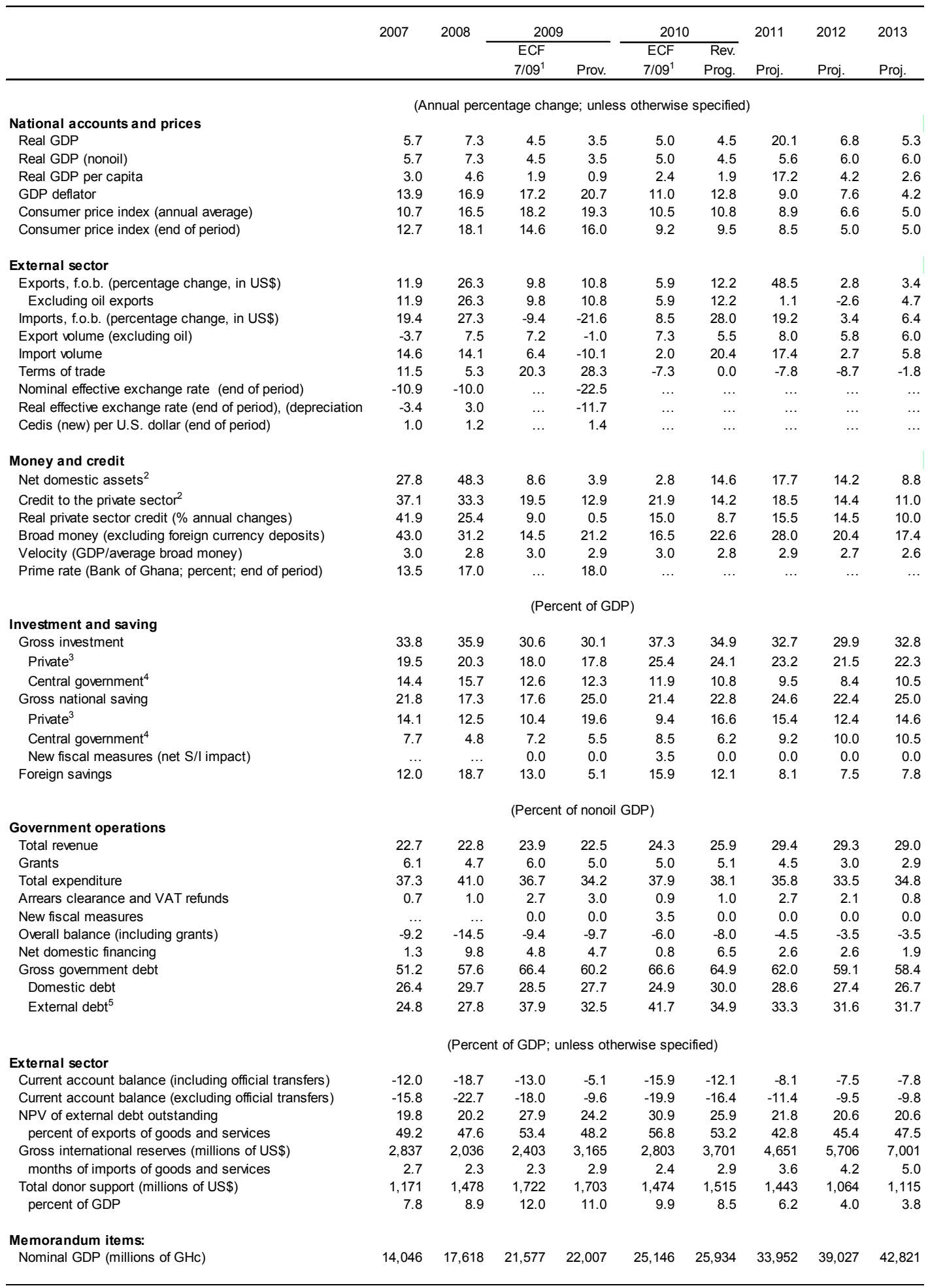

Sources: Data provided by Ghanaian authorities; and IMF staff estimates and projections.

${ }^{1}$ After including SDR allocation in 2009.

${ }^{2}$ Percent of broad money (including foreign currency deposits) at the beginning of the period.

${ }^{3}$ Including public enterprises and errors and omissions.

${ }^{4}$ Before new fiscal measures.

${ }^{5}$ Includes potential new exceptional financing starting in 2010-12. 
Table 2A. Ghana: Summary of Central Government Budgetary Operations, 2007-131

\begin{tabular}{|c|c|c|c|c|c|c|c|c|c|}
\hline & \multirow[t]{2}{*}{2007} & \multirow[t]{2}{*}{2008} & \multicolumn{2}{|c|}{2009} & \multicolumn{2}{|c|}{2010} & \multirow{2}{*}{$\begin{array}{l}2011 \\
\text { Proj. }\end{array}$} & \multirow{2}{*}{$\begin{array}{l}2012 \\
\text { Proj. }\end{array}$} & \multirow{2}{*}{$\begin{array}{l}2013 \\
\text { Proj }\end{array}$} \\
\hline & & & $\begin{array}{l}\text { ECF } \\
7 / 09\end{array}$ & Prov. & $\begin{array}{l}\text { ECF } \\
7 / 09 \\
\end{array}$ & $\begin{array}{l}\text { Rev. } \\
\text { Prog. }\end{array}$ & & & \\
\hline & \multicolumn{8}{|c|}{ (Percent of nonoil GDP, unless otherwise specified) } & \\
\hline Total revenue and grants & 28.8 & 27.5 & 30.0 & 27.5 & 29.3 & 31.1 & 33.9 & 32.3 & 31.9 \\
\hline Revenue & 22.7 & 22.8 & 24.0 & 22.5 & 24.3 & 25.9 & 29.4 & 29.3 & 29.0 \\
\hline Tax revenue & 21.3 & 21.5 & 22.4 & 20.1 & 22.7 & 22.6 & 26.1 & 26.0 & 25.7 \\
\hline Direct taxes & 6.7 & 7.1 & 7.3 & 7.8 & 7.4 & 9.2 & 12.7 & 12.6 & 12.3 \\
\hline Indirect taxes & 10.5 & 10.3 & 10.7 & 8.8 & 10.8 & 9.3 & 9.4 & 9.4 & 9.4 \\
\hline Trade taxes & 4.1 & 4.1 & 4.5 & 3.5 & 4.6 & 4.0 & 4.1 & 4.1 & 4.1 \\
\hline Nontax revenue & 0.8 & 0.7 & 0.9 & 2.1 & 0.9 & 2.8 & 2.8 & 2.8 & 2.7 \\
\hline Grants & 6.1 & 4.7 & 6.0 & 5.0 & 5.0 & 5.1 & 4.5 & 3.0 & 2.9 \\
\hline Total expenditure & 37.3 & 41.0 & 36.7 & 34.2 & 37.9 & 38.1 & 35.8 & 33.5 & 34.8 \\
\hline Recurrent expenditure & 23.0 & 25.4 & 24.1 & 22.3 & 25.9 & 27.3 & 25.0 & 23.7 & 22.9 \\
\hline Recurrent Non-interest expenditure & 19.8 & 21.5 & 19.8 & 17.6 & 22.1 & 22.2 & 20.3 & 19.9 & 19.7 \\
\hline Wages and salaries ${ }^{2}$ & 10.1 & 11.3 & 10.7 & 11.3 & 11.7 & 13.2 & 12.8 & 12.4 & 12.3 \\
\hline Goods and services ${ }^{2}$ & 4.0 & 3.7 & 3.6 & 2.8 & 1.9 & 2.0 & 2.0 & 2.0 & 2.0 \\
\hline Transfers & 4.4 & 5.0 & 4.5 & 2.7 & 7.4 & 5.5 & 4.1 & 4.0 & 4.0 \\
\hline $\mathrm{o} / w$ Utility company \& refinery subsidies ${ }^{3}$ & 0.0 & 1.2 & 0.0 & 0.0 & 2.9 & 1.4 & 0.0 & 0.0 & 0.0 \\
\hline Reserve Fund & 1.4 & 1.6 & 1.0 & 0.8 & 1.2 & 1.4 & 1.4 & 1.4 & 1.4 \\
\hline Interest costs & 3.1 & 3.9 & 4.4 & 4.7 & 3.8 & 5.1 & 4.6 & 3.8 & 3.2 \\
\hline domestic & 2.3 & 2.7 & 2.9 & 3.5 & 2.4 & 4.0 & 3.6 & 2.8 & 2.3 \\
\hline foreign & 0.8 & 1.1 & 1.5 & 1.2 & 1.3 & 1.1 & 1.1 & 1.0 & 0.9 \\
\hline Capital expenditure (total) & 14.4 & 15.7 & 12.6 & 11.9 & 12.0 & 10.8 & 10.8 & 9.8 & 11.9 \\
\hline Domestic & 9.2 & 10.5 & 5.8 & 4.5 & 6.2 & 5.1 & 5.7 & 6.9 & 9.2 \\
\hline o/w Shared Growth Fund (oil-financed) & & & & & & & 0.5 & 1.8 & 4.2 \\
\hline Foreign & 5.2 & 5.2 & 6.8 & 7.4 & 5.8 & 5.7 & 5.1 & 2.9 & 2.7 \\
\hline VAT refunds & -0.2 & -0.1 & -0.2 & -0.1 & -0.2 & -0.2 & -0.2 & -0.2 & -0.2 \\
\hline Arrears clearance & -0.5 & -0.8 & -2.5 & -2.8 & -0.7 & -0.9 & -2.5 & -2.1 & -0.4 \\
\hline Other fiscal measures & $\ldots$ & $\ldots$ & $\ldots$ & $\ldots$ & 3.5 & 0.0 & 0.0 & 0.0 & 0.0 \\
\hline Overall balance ${ }^{4}$ & -9.2 & -14.5 & -9.4 & -9.7 & -6.0 & -8.0 & -4.5 & -3.5 & -3.5 \\
\hline excluding oil related operations & $\ldots$ & $\ldots$ & $\ldots$ & $\ldots$ & $\ldots$ & $\ldots$ & -9.9 & -8.9 & -8.5 \\
\hline Discrepancy & -0.3 & 0.8 & 0.0 & -0.3 & 0.0 & 0.0 & 0.0 & 0.0 & 0.0 \\
\hline Total financing & 8.9 & 15.3 & 9.4 & 9.4 & 6.0 & 8.0 & 4.5 & 3.5 & 3.5 \\
\hline Divestiture receipts $(\text { net })^{5}$ & 0.8 & 4.0 & 0.0 & 0.0 & 0.0 & -1.7 & 0.0 & 0.0 & 0.0 \\
\hline Foreign (net) & 6.1 & 1.0 & 4.0 & 4.3 & 4.7 & 2.7 & 1.5 & 0.6 & 1.3 \\
\hline Exceptional financing (debt relief, bilateral) & 0.7 & 0.4 & 0.6 & 0.3 & 0.5 & 0.5 & 0.4 & 0.3 & 0.3 \\
\hline Domestic (net) & 1.3 & 9.8 & 4.8 & 4.7 & 0.8 & 6.5 & 2.6 & 2.6 & 1.9 \\
\hline Banking system & -2.3 & 7.1 & 2.6 & 3.5 & -1.7 & 3.8 & 1.3 & 1.3 & 1.0 \\
\hline Non-bank & 3.6 & 2.7 & 2.2 & 1.3 & 2.5 & 2.7 & 1.3 & 1.3 & 1.0 \\
\hline \multicolumn{10}{|l|}{ Fiscal operations on commitment basis } \\
\hline Overall balance (cash basis) & -9.2 & -14.5 & -9.4 & -9.7 & -6.0 & -8.0 & -4.5 & -3.5 & -3.5 \\
\hline Minus: old arrears cleared & -0.5 & -0.8 & -2.5 & -2.8 & -0.7 & -0.9 & -2.5 & -2.1 & -0.4 \\
\hline Plus: new arrears accumulated & -1.0 & -6.4 & -0.8 & -4.2 & -0.8 & -0.4 & -0.5 & -0.5 & -0.5 \\
\hline Overall balance (commitment basis) & -9.7 & -20.1 & -7.8 & -11.0 & -6.1 & -7.6 & -2.5 & -1.9 & -3.5 \\
\hline \multicolumn{10}{|l|}{ Memorandum items: } \\
\hline Total poverty spending & 9.4 & 9.0 & 8.4 & 8.4 & 8.5 & 8.4 & 9.1 & 9.1 & 9.1 \\
\hline Revenue transfers to statutory funds & 5.8 & 5.6 & 6.4 & 3.3 & 6.3 & 6.1 & 6.0 & 6.0 & 6.0 \\
\hline Tax exemptions & 1.6 & 2.7 & 2.2 & 1.4 & 1.7 & 0.9 & 0.9 & 1.0 & $\ldots$ \\
\hline Primary balance & -6.1 & -10.7 & -5.1 & -5.0 & -5.7 & -2.9 & 0.1 & 0.3 & -0.3 \\
\hline Budget balance (commitment basis) & -9.7 & -20.1 & -7.8 & -11.0 & -6.1 & -7.6 & -2.5 & -1.9 & -3.5 \\
\hline Outstanding domestic payments arrears & 1.0 & 6.4 & $\ldots$ & 6.5 & $\ldots$ & 5.1 & 2.4 & 0.5 & 0.5 \\
\hline Total government debt & 51.2 & 57.6 & 66.4 & 60.2 & 66.6 & 64.9 & 62.0 & 59.1 & 58.4 \\
\hline Domestic debt & 26.4 & 29.7 & 28.5 & 27.7 & 24.9 & 30.0 & 28.6 & 27.5 & 26.7 \\
\hline External debt & 24.8 & 27.8 & 37.9 & 32.5 & 41.7 & 34.9 & 33.3 & 31.6 & 31.7 \\
\hline Annual oil revenue & $\ldots$ & $\ldots$ & $\ldots$ & $\ldots$ & $\ldots$ & $\ldots$ & 5.4 & 5.4 & 5.0 \\
\hline Shared Growth Fund (oil-financed projects) & $\ldots$ & $\ldots$ & $\ldots$ & $\ldots$ & $\ldots$ & $\ldots$ & 0.5 & 1.8 & 4.2 \\
\hline Nominal nonoil GDP (millions of GHc) & 14,046 & 17,618 & 21,577 & 22,007 & 25,146 & 25,934 & 29,900 & 34,390 & 38,063 \\
\hline
\end{tabular}

Sources: Ghanaian authorities; and IMF staff estimates and projections.

${ }^{1}$ Above-the-line data for domestic recurrent and capital expenditure are presented on a cash basis.

${ }^{2}$ From 2010, reflects reforms to the remuneration framework, including shifting certain allowances from goods \& services to wages \& salaries.

${ }^{3}$ From 2010, assumes full cost-recovery pricing for electricity tariffs.

${ }^{4}$ Includes cumulative fiscal measures.

${ }^{5}$ Negative sign represents increase in equity in SOEs. 
Table 2B. Ghana: Summary of Central Government Budgetary Operations, 2007-13 ${ }^{1}$

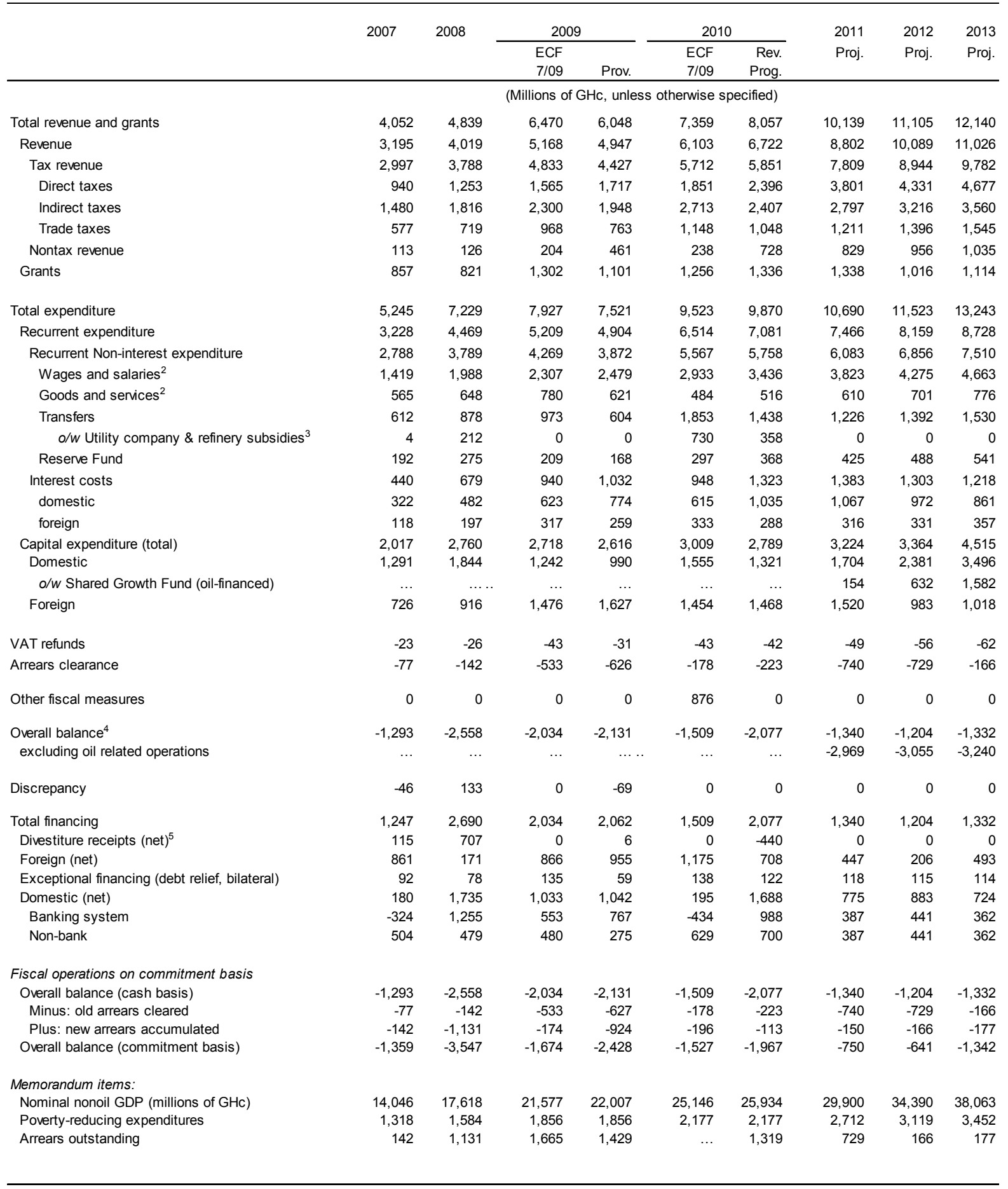

Sources: Ghanaian authorities; and IMF staff estimates and projections.

${ }^{1}$ Above-the-line data for domestic recurrent and capital expenditure are presented on a cash basis.

${ }^{2}$ From 2010, reflects reforms to the remuneration framework, including shifting certain allowances from goods \& services to wages \& salaries.

${ }^{3}$ From 2010, assumes full cost-recovery pricing for electricity tariffs.

${ }^{4}$ Including cumulative fiscal measures.

${ }^{5}$ Negative sign represents increase in equity in SOEs. 
Table 3. Ghana: Domestic Payments Arrears, 2008-12

\begin{tabular}{|c|c|c|c|c|c|c|c|c|c|c|c|c|c|}
\hline & \multirow{2}{*}{$\begin{array}{l}2008 \\
\text { Stock }\end{array}$} & \multicolumn{3}{|c|}{2009} & \multicolumn{3}{|c|}{2010} & \multicolumn{3}{|c|}{2011} & \multicolumn{3}{|c|}{2012} \\
\hline & & Repayments & Accumulation & $\begin{array}{r}\text { End-period } \\
\text { Stock } \\
\end{array}$ & Repayments & Accumulation $^{1}$ & $\begin{array}{r}\text { End-period } \\
\text { Stock } \\
\end{array}$ & Repayments & Accumulation $^{1}$ & $\begin{array}{r}\text { End-period } \\
\text { Stock } \\
\end{array}$ & Repayments & Accumulation ${ }^{1}$ & $\begin{array}{r}\text { End-period } \\
\text { Stock } \\
\end{array}$ \\
\hline & \multicolumn{13}{|c|}{ ( $\mathrm{GH} \phi$ millions) } \\
\hline Project Arrears & 830 & 362 & 386 & 855 & 223 & 113 & 745 & 453 & 150 & 442 & 442 & 166 & 166 \\
\hline Roads & 125 & 76 & 138 & 188 & 160 & 50 & 78 & 78 & 66 & 66 & 66 & 73 & 73 \\
\hline Non-roads & 705 & 286 & 248 & 667 & 63 & 63 & 667 & 376 & 84 & 376 & 376 & 93 & 93 \\
\hline Energy & 581 & 186 & 94 & 489 & 32 & 0 & 458 & 229 & 0 & 229 & 229 & 0 & 0 \\
\hline Other & 124 & 100 & 154 & 178 & 32 & 63 & 209 & 147 & 84 & 147 & 147 & 93 & 93 \\
\hline Trust/Statutory Funds & 301 & 265 & 538 & 574 & 0 & 0 & 574 & 287 & 0 & 287 & 287 & 0 & 0 \\
\hline Education Fund & 49 & 49 & 101 & 101 & 0 & 0 & 101 & 50 & 0 & 50 & 50 & 0 & 0 \\
\hline District Assembly common Fund & 35 & 35 & 172 & 172 & 0 & 0 & 172 & 86 & 0 & 86 & 86 & 0 & 0 \\
\hline National Health Fund & 100 & 100 & 164 & 164 & 0 & 0 & 164 & 82 & 0 & 82 & 82 & 0 & 0 \\
\hline Social Security fund & 109 & 73 & 100 & 136 & 0 & 0 & 136 & 68 & 0 & 68 & 68 & 0 & 0 \\
\hline Other & 8 & 8 & 0 & 0 & 0 & 0 & 0 & 0 & 0 & 0 & 0 & 0 & 0 \\
\hline Total & 1,131 & 627 & 924 & 1,429 & 223 & 113 & 1,319 & 740 & 150 & 729 & 729 & 166 & 166 \\
\hline (Percent of GDP) & 6.4 & 2.8 & 4.2 & 6.5 & 0.9 & 0.4 & 5.1 & 2.2 & 0.4 & 2.1 & 1.9 & 0.4 & 0.4 \\
\hline
\end{tabular}

Source: Ghanaian authorities.

${ }^{1}$ Represents provision for spending contracted in 2009, but not yet paid by the end of the fiscal year. 
Table 4. Ghana: Monetary Survey, 2007-13

(Millions of cedis, unless otherwise indicated)

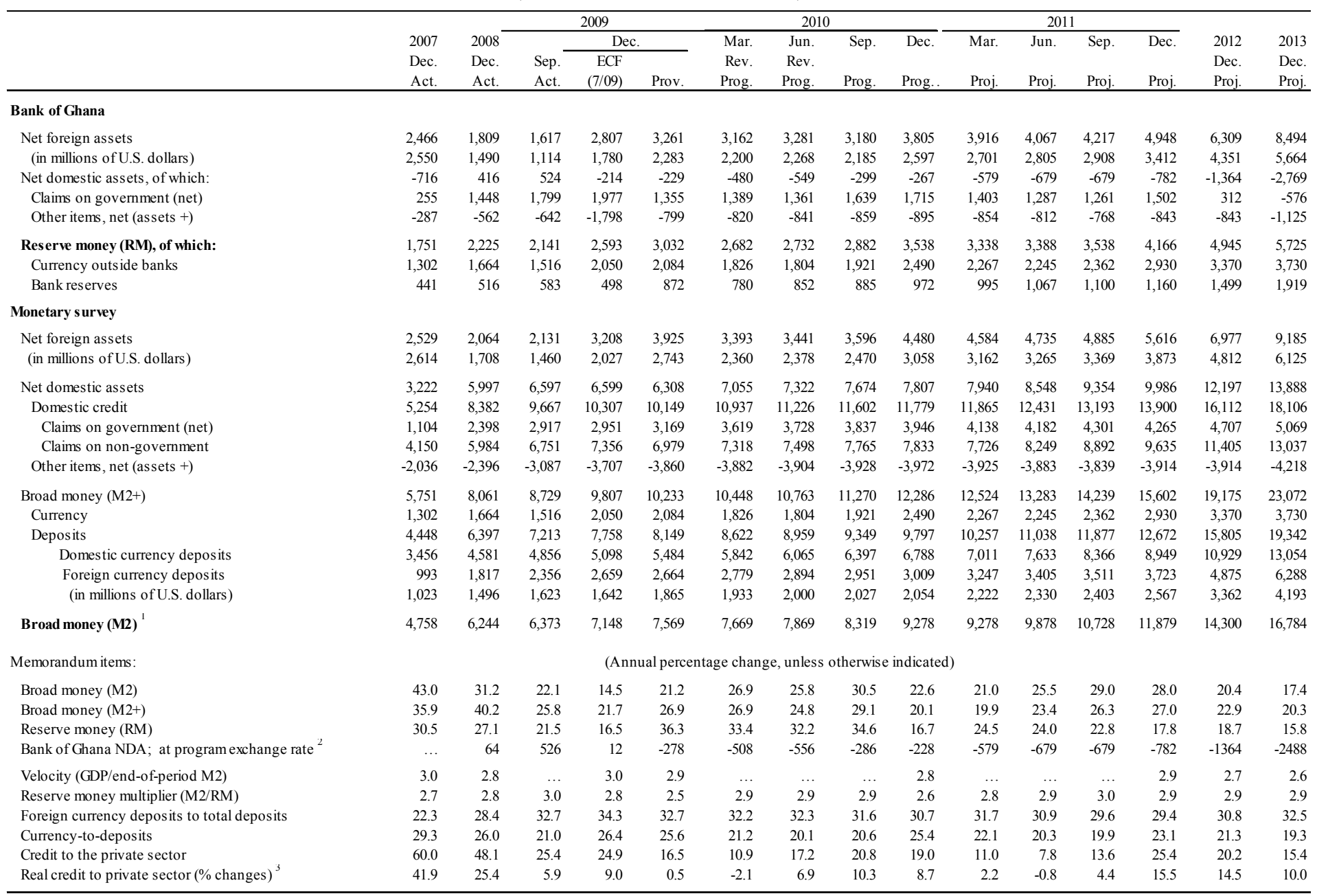

Sources: Bank of Ghana, and IMF staff estimates and projections.

${ }^{1}$ Excluding foreign currency deposits.

${ }^{2}$ In millions of cedis. The program exchange rate is GHc 1.45 per U.S. dollar.

${ }^{3}$ Deflated by the Consumer Price Index 
Table 5. Ghana: Balance of Payments, 2007-13

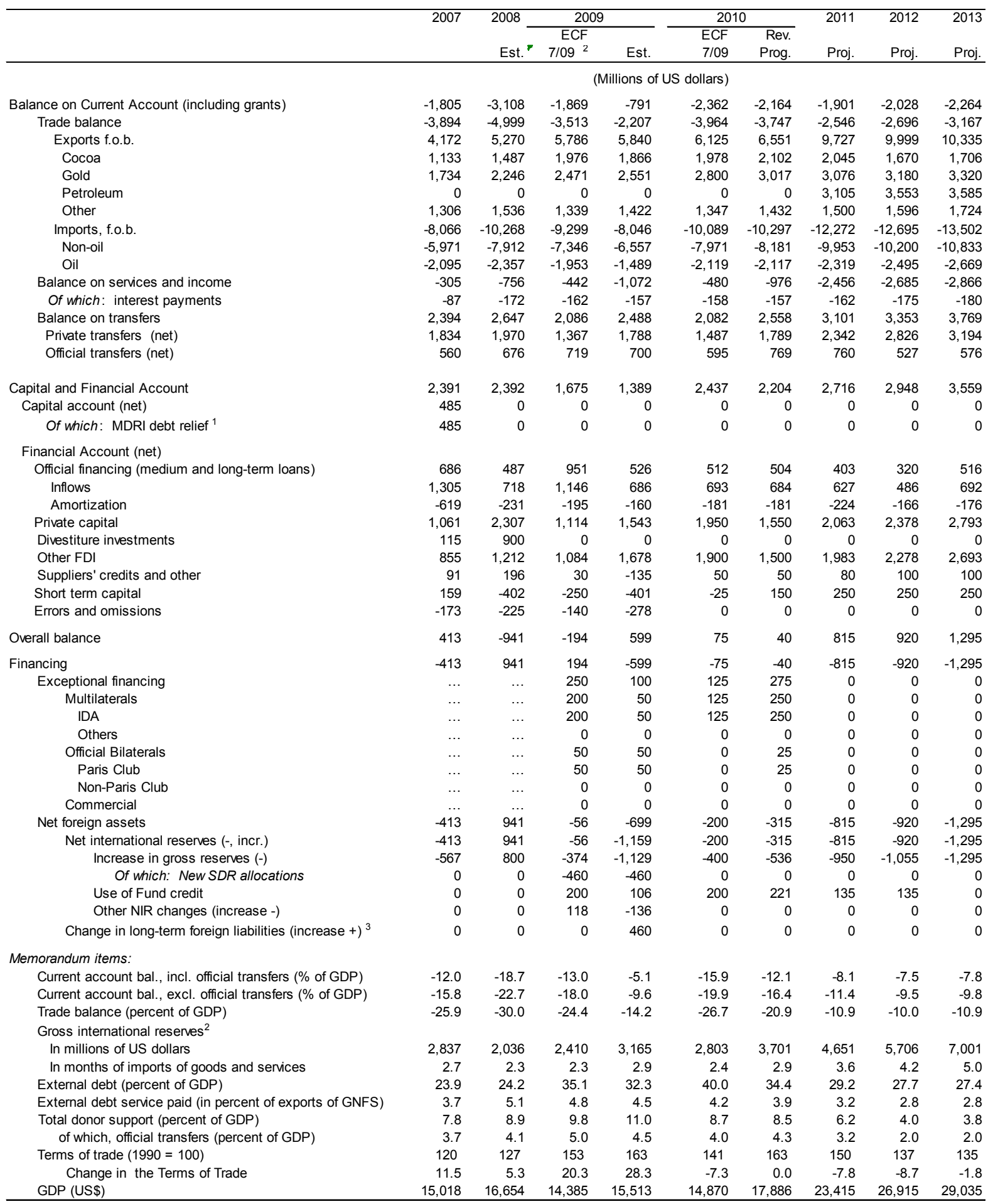

Sources: Bank of Ghana; and IMF staff estimates and projections.

${ }^{1}$ Including MDRI debt relief from African Development Fund in 2007.

${ }^{2}$ After including SDR allocations in 2009.

${ }^{3}$ Includes the new SDR allocations (US $\$ 460$ million). 
Table 6. Ghana: Financial Soundness Indicators, 2003-10

(Percent, end-of-period, unless otherwise specified)

\begin{tabular}{|c|c|c|c|c|c|c|c|c|c|}
\hline & 2003 & 2004 & 2005 & 2006 & 2007 & 2008 & 2009 & \multicolumn{2}{|c|}{2010} \\
\hline & & & & & & & & Jan & Feb \\
\hline \multicolumn{10}{|l|}{ Capital adequacy: } \\
\hline Regulatory capital ratio & 9.3 & 13.9 & 16.2 & 15.8 & 14.8 & 13.8 & 18.2 & 17.4 & 19.7 \\
\hline Regulatory tier 1 capital ratio & 6.6 & 6.4 & 7.2 & 15.0 & 13.6 & 12.8 & 17.0 & 17.0 & 18.5 \\
\hline \multicolumn{10}{|l|}{ Asset quality: } \\
\hline Nonperforming loans to total gross loans & 18.3 & 16.3 & 13.0 & 7.9 & 6.4 & 7.7 & 14.9 & 19.7 & 20.0 \\
\hline Credit to total assets & 41.7 & 44.0 & 48.7 & 45.0 & 50.3 & 52.3 & 43.8 & 43.2 & 43.1 \\
\hline Loan loss provision to total gross loans & 15.4 & 13.8 & 8.5 & 7.4 & 5.5 & 6.3 & 11.1 & 12.9 & 12.7 \\
\hline \multicolumn{10}{|l|}{ Earnings and profitability: } \\
\hline Return on assets, before taxes (average) & 6.2 & 5.8 & 4.6 & 4.8 & 3.7 & 3.2 & 2.8 & 5.2 & 4.0 \\
\hline Return on equity, before taxes (average) & 32.7 & 33.7 & 23.6 & 39.6 & 35.8 & 23.7 & 17.5 & 31.0 & 32.2 \\
\hline Interest margin to gross income & 63.2 & 62.9 & 64.0 & 51.8 & 46.1 & 41.3 & 39.4 & 31.5 & 34.1 \\
\hline Interest spread 1 & 23.13 & 20.3 & 19.3 & 18.3 & 18.3 & 20.8 & 17.1 & 17.4 & 17.7 \\
\hline \multicolumn{10}{|l|}{ Liquidity: } \\
\hline Core liquid assets to total assets ratio & 29.0 & 25.4 & 20.7 & 23.5 & 23.4 & 25.2 & 26.3 & 25.2 & 23.5 \\
\hline Broad liquid assets to total assets ratio & 57.0 & 53.5 & 47.0 & 46.3 & 40.7 & 39.4 & 47.2 & 48.6 & 47.8 \\
\hline Core liquid assets to short-term liabilities ratio & 40.8 & 34.6 & 42.8 & 31.4 & 31.0 & 33.5 & 34.5 & 33.4 & 30.9 \\
\hline Broad liquid assets to short-term liabilities ratio & 80.2 & 72.8 & 97.4 & 61.9 & 54.1 & 52.4 & 62.0 & 64.4 & 63.0 \\
\hline \multicolumn{10}{|l|}{ Exposure to foreign exchange risk: } \\
\hline Share of foreign currency deposits in total deposits & 30.8 & 29.3 & 26.3 & 28.1 & 22.3 & 28.4 & 32.7 & 29.9 & 28.8 \\
\hline Share of foreign liabilities in total liabilities & 4.0 & 2.8 & 2.4 & 4.0 & 8.1 & 7.0 & 6.2 & 5.9 & 6.2 \\
\hline
\end{tabular}

Source: Bank of Ghana.

${ }^{1}$ Average lending rate minus average (saving and demand) deposit rate. 
Table 7. Ghana: External Financing Requirements and Sources, 2006-14 (Millions of U.S. dollars)

\begin{tabular}{|c|c|c|c|c|c|c|c|c|c|}
\hline \multicolumn{10}{|c|}{ IMF Staff Projections } \\
\hline & 2006 & 2007 & 2008 & 2009 & 2010 & 2011 & 2012 & 2013 & 2014 \\
\hline Total requirements & $-5,006$ & $-3,552$ & $-3,215$ & $-2,779$ & $-3,650$ & $-3,835$ & $-3,776$ & $-4,311$ & $-3,786$ \\
\hline Current account (excl. official transfers) & $-1,658$ & $-2,366$ & $-3,784$ & $-1,490$ & $-2,934$ & $-2,660$ & $-2,555$ & $-2,840$ & $-2,187$ \\
\hline Debt amortization & $-2,973$ & -619 & -231 & -160 & -181 & -224 & -166 & -176 & -250 \\
\hline Gross reserves accumulation & -375 & -567 & 800 & $-1,129$ & -536 & -950 & $-1,055$ & $-1,295$ & $-1,349$ \\
\hline Total sources & 5,006 & 3,552 & 3,215 & 2,779 & 3,650 & 3,835 & 3,776 & 4,311 & 3,786 \\
\hline IMF & -265 & 0 & 0 & 106 & 221 & 135 & 135 & 0 & -20 \\
\hline Other IFIs & 0 & 0 & 0 & 100 & 275 & 0 & 0 & 0 & 0 \\
\hline Capital flows & 5,271 & 3,552 & $3,215^{r}$ & 2,573 & 3,154 & 3,700 & 3,641 & 4,311 & 3,806 \\
\hline Foreign direct investment (net) & 636 & 855 & 1,212 & 1,678 & 1,500 & 1,983 & 2,278 & 2,693 & 2,168 \\
\hline Disbursement from official creditors & 894 & 1,840 & 1,406 & 1,637 & 1,454 & 1,387 & 1,013 & 1,268 & 1,284 \\
\hline Other flows ${ }^{1}$ & 3,741 & 857 & 597 & -741 & 200 & 330 & 350 & 350 & 354 \\
\hline
\end{tabular}

Sources: Ghanaian authorities and IMF staff estimates and projections.

${ }^{1}$ Includes all other net financial flows and errors and omissions. 
Table 8. Ghana: Indicators of Capacity to Repay the Fund, 2010-22 ${ }^{12}$

\begin{tabular}{|c|c|c|c|c|c|c|c|c|c|c|c|c|c|}
\hline & 2010 & 2011 & 2012 & 2013 & 2014 & 2015 & 2016 & 2017 & 2018 & 2019 & 2020 & 2021 & 2022 \\
\hline & \multicolumn{13}{|c|}{ Projections } \\
\hline \multicolumn{14}{|c|}{ Fund obligations based on existing credit (in millions of SDRs) } \\
\hline Principal & 0.0 & 10.5 & 21.1 & 21.1 & 21.1 & 34.6 & 24.1 & 13.5 & 13.5 & 13.5 & 0.0 & 0.0 & 0.0 \\
\hline Charges and interest & 1.0 & 1.0 & 0.9 & 0.8 & 0.7 & 0.6 & 0.4 & 0.3 & 0.3 & 0.2 & 0.2 & 0.2 & 0.2 \\
\hline \multicolumn{14}{|c|}{ Fund obligations based on existing and prospective credit (in millions of SDRs) } \\
\hline Principal & 0.0 & 10.5 & 21.1 & 21.1 & 21.1 & 42.8 & 57.8 & 64.5 & 77.5 & 77.5 & 55.8 & 30.2 & 13.0 \\
\hline Charges and interest & 1.5 & 2.0 & 2.3 & 2.4 & 2.3 & 2.2 & 1.9 & 1.6 & 1.2 & 0.8 & 0.5 & 0.3 & 0.2 \\
\hline \multicolumn{14}{|l|}{ Total obligations based on existing and prospective credit } \\
\hline In millions of SDRs & 1.5 & 12.5 & 23.4 & 23.5 & 23.4 & 44.9 & 59.7 & 66.1 & 78.7 & 78.3 & 56.3 & 30.5 & 13.2 \\
\hline In millions of US $\$$ & 2.2 & 19.2 & 35.9 & 36.0 & 35.9 & 68.9 & 91.6 & 101.4 & 120.7 & 120.1 & 86.4 & 46.8 & 20.2 \\
\hline In percent of gross international reserves & 0.1 & 0.4 & 0.6 & 0.5 & 0.4 & 0.7 & 0.9 & 1.0 & 1.2 & 1.2 & 0.9 & 0.5 & 0.2 \\
\hline In percent of exports of goods and services & 0.0 & 0.2 & 0.3 & 0.3 & 0.3 & 0.5 & 0.7 & 0.7 & 0.8 & 0.8 & 0.5 & 0.3 & 0.1 \\
\hline In percent of debt service ${ }^{2}$ & 0.7 & 4.8 & 10.6 & 10.1 & 8.0 & 11.5 & 12.6 & 5.9 & 10.1 & 8.2 & 5.0 & 2.4 & 0.9 \\
\hline In percent of GDP & 0.0 & 0.1 & 0.1 & 0.1 & 0.1 & 0.2 & 0.3 & 0.3 & 0.3 & 0.3 & 0.2 & 0.1 & 0.0 \\
\hline In percent of quota & 0.4 & 3.4 & 6.3 & 6.4 & 6.3 & 12.2 & 16.2 & 17.9 & 21.3 & 21.2 & 15.3 & 8.3 & 3.6 \\
\hline \multicolumn{14}{|l|}{ Outstanding Fund credit ${ }^{3}$} \\
\hline In millions of SDRs & 320.1 & 396.0 & 461.3 & 440.2 & 419.1 & 376.3 & 318.5 & 254.0 & 176.5 & 99.0 & 43.2 & 13.0 & 0.0 \\
\hline In millions of US\$ & 490.9 & 605.5 & 706.1 & 674.5 & 642.8 & 577.2 & 488.5 & 389.5 & 270.7 & 151.9 & 66.3 & 19.9 & 0.0 \\
\hline In percent of gross international reserves & 13.3 & 13.0 & 12.3 & 9.6 & 7.6 & 5.9 & 4.7 & 3.9 & 2.6 & 1.5 & 0.7 & 0.2 & 0.0 \\
\hline In percent of exports of goods and services & 5.6 & 5.0 & 5.7 & 5.3 & 4.9 & 4.2 & 3.5 & 2.7 & 1.8 & 1.0 & 0.4 & 0.1 & 0.0 \\
\hline In percent of debt service ${ }^{3}$ & 144.7 & 151.8 & 207.9 & 189.3 & 143.9 & 96.7 & 67.3 & 22.8 & 22.6 & 10.4 & 3.9 & 1.0 & 0.0 \\
\hline In percent of GDP & 2.7 & 2.6 & 2.6 & 2.3 & 2.1 & 1.8 & 1.4 & 1.1 & 0.7 & 0.4 & 0.1 & 0.0 & 0.0 \\
\hline In percent of quota & 86.7 & 107.3 & 125.0 & 119.3 & 113.6 & 102.0 & 86.3 & 68.8 & 47.8 & 26.8 & 11.7 & 3.5 & 0.0 \\
\hline Net use of Fund credit (in millions of SDRs) & 145.5 & 73.9 & 63.0 & -23.5 & -23.4 & -44.9 & -59.7 & -66.1 & -78.7 & -78.3 & -56.3 & -30.5 & -13.2 \\
\hline Disbursements & 147.0 & 86.4 & 86.4 & 0.0 & 0.0 & 0.0 & 0.0 & 0.0 & 0.0 & 0.0 & 0.0 & 0.0 & 0.0 \\
\hline Repayments & 1.5 & 12.5 & 23.4 & 23.5 & 23.4 & 44.9 & 59.7 & 66.1 & 78.7 & 78.3 & 56.3 & 30.5 & 13.2 \\
\hline \multicolumn{14}{|l|}{ Memorandum items: } \\
\hline Nominal GDP (in millions of US\$) & 17,886 & 23,415 & 26,915 & 29,035 & 30,970 & 32,959 & 34,613 & 36,605 & 38,967 & 41,608 & 44,526 & 47,844 & 51,534 \\
\hline Exports of goods and services (in millions of US\$) & 8,804 & 12,052 & 12,350 & 12,729 & 13,188 & 13,685 & 13,828 & 14,237 & 14,805 & 15,447 & 16,264 & 17,290 & 18,520 \\
\hline Gross international reserves (in millions of US $\$$ ) & 3,701 & 4,651 & 5,731 & 7,049 & 8,419 & 9,721 & 10,372 & 10,061 & 10,218 & 10,142 & 9,885 & 9,485 & 9,523 \\
\hline Debt service (in millions of US\$) 2/ & 339.3 & 398.8 & 339.5 & 356.3 & 446.5 & 597.1 & 725.6 & $1,705.0$ & $1,196.3$ & $1,458.2$ & $1,720.4$ & $1,987.4$ & $2,256.6$ \\
\hline Quota (millions of SDRs) & 369 & 369 & 369 & 369 & 369 & 369 & 369 & 369 & 369 & 369 & 369 & 369 & 369 \\
\hline
\end{tabular}

MF staff estimates and projections.

Includes prospective PRGF disbursements of SDR 387.45 million (105 percent of quota).

No temporary interest relief assumed pending receipt of required consents to the LIC reforms from lenders and contributors to the PRGF-ESF Trust.

${ }_{3}$ Total debt service includes IMF repayments. 


\section{APPENDIX I-LETTER OF INTENT}

May 13, 2010

Mr. Dominique Strauss-Kahn

Managing Director

International Monetary Fund

Washington, DC 20431

Dear Mr. Strauss-Kahn:

The government, on assuming office in 2009 , faced very serious economic challenges. The fiscal deficit in 2008 had risen to 141/2 percent of GDP, excluding new domestic expenditure arrears of 4.2 percent of GDP. Efforts to address these imbalances were complicated by the spreading impact of the global financial crisis. Although strong cocoa and gold exports partly insulated Ghana from the worst effects of the global recession, a shortfall in capital inflows exacerbated underlying balance of payments difficulties. The government requested financing from the IMF as well as scaled up support from other development partners to provide the country with breathing space to adopt a program of fiscal consolidation and strengthened public finance management.

Considerable progress was made in implementing the economic program in 2009. The fiscal deficit was substantially reduced from 2008 levels. At the same time, good progress was made in launching programs to reform public financial management and revenue administration, supported by IMF and other technical assistance. For 2010, policies have been adopted to achieve a further reduction in the fiscal deficit, and ambitious goals have been established for carrying forward the structural fiscal reforms. These and other components of the government's economic stabilization and reform program are described in the attached Memorandum of Economic and Financial Policies (MEFP).

The MEFP also describes corrective policies adopted by the government in response to breaches of the end-September 2009 performance criterion under the Extended Credit Facility (ECF) arrangement for the overall fiscal deficit, as well as the continuous performance criterion on contracting or guaranteeing new external nonconcessional debt. Based on these policies, the government requests that the IMF Executive Board grant waivers for these performance criteria. The government also requests approval of the proposed modifications to the performance criteria for end-June 2010 and establishment of the proposed new performance criteria and structural benchmarks for the period through June 2011 as described in the MEFP.

In support of its policies, the government requests that the Executive Board of the IMF complete the first and second reviews of Ghana's ECF arrangement and approve 
disbursement of the second and third tranches of the loan, based on proposed rephasing of disbursements as set forth in the attached schedule to the MEFP.

The Government of Ghana will provide such information as the Fund may request in connection with progress in implementing its economic and financial policies. The government believes that the policies set out in this letter are adequate to achieve the objectives of its program, but it will take any further measures that may become appropriate for this purpose. The Government will consult with the Fund on the adoption of these measures, and in advance of revisions to the policies contained in the MEFP, in accordance with the Fund's policies on such consultations.

We have no objection to publication of the staff report for the first and second reviews under the ECF arrangement, this letter of intent, and the attached memorandum of economic and financial policies and technical memorandum of understanding.

/s/

Dr. Kwabena Duffuor

Minister of Finance and

Economic Planning
$/ \mathrm{s} /$

Mr. K.B. Amissah-Arthur

Governor

Bank of Ghana 


\section{APPENDIX I-ATTACHMENT I}

\section{Memorandum of Economic and Financial Policies, 2010-12}

1. This memorandum summarizes the government's assessment of Ghana's current economic situation (Section I), the government's policies that are being adopted to address the challenges that the country faces (Section II), and the quantitative targets and structural policies that will be monitored in the context of the IMF's financing arrangement (Section III).

\section{Recent Developments and 2009 Program Performance}

\section{A. Growth and Inflation}

2. Ghana weathered the global recession relatively well, despite some slowing of overall economic growth, with favorable global market conditions for cocoa and gold exports, and good rainfalls supporting hydroelectricity production and agricultural output. However, remittances declined modestly and access to private external financing tightened.

3. Consumer price inflation fell to 13.3 percent in March 2010, after peaking at 20.7 percent in June 2009. The surge in inflation during 2008-09 from around 10 percent in 2007 reflected highly expansionary fiscal policy in 2008, pass-through from the 2007-08 global food and fuel price increases, and currency depreciation between mid-2008 and mid2009. Since mid-2009, the decline in inflation reflected tighter fiscal and monetary policies and appreciation of the cedi against the U.S. dollar since July 2009. Although inflation remains slightly higher than the target under the program, it has been within the inner consultation band (Table 1 attached).

\section{B. Fiscal Performance}

4. With tight expenditure control, the fiscal deficit met the adjusted end-December 2009 program ceiling, after exceeding the September 2009 ceiling (Table 1). The full-year deficit was equivalent to 9.7 percent of GDP, down from 14.5 percent of GDP in 2008.

5. Revenues. Budget management in 2009 was complicated by a shortfall in total revenues and grants of GH $\not 422$ million (1.9 percent of GDP). Direct tax collections overperformed, reflecting strong increases in personal income taxes following partial computerization of payroll returns, an increase of up to 50 percent in the airport tax in March 2009, and adoption of the National Fiscal Stabilization Levy ${ }^{1}$ in July 2009. Nontax revenues also exceeded program projections due to an unbudgeted profit transfer from the

\footnotetext{
${ }^{1}$ A temporary profit tax levied on corporations in selected sectors.
} 
Ghana Cocoa Board amounting to 1.3 percent of GDP. This was more than offset, however, by lower than projected indirect taxes on account of an apparently sharper than programmed downturn in domestic demand. Receipts of grants fell short of programmed levels by nearly 1 percent of GDP, reflecting capacity constraints and slow disbursement procedures.

6. Expenditures. Cash outlays in 2009 fell $2 \frac{1}{2}$ percent of GDP below programmed levels, despite an overrun in the wage bill (by 0.6 percent of GDP) and domestic interest costs ( 0.6 percent of GDP). Faced with limited revenues, the government accumulated new domestic payments arrears in 2009 to domestic suppliers of goods and services (1.8 percent of GDP) and to the government's own statutory funds that finance projects in various sectors $\left(2.4\right.$ percent of GDP). ${ }^{2}$

7. Expenditure arrears. The discovery of expenditure arrears from 2008 made fiscal management in 2009 more challenging. A stock take was conducted across spending units by external auditors through September 2009. Based on this exercise, the stock of domestic expenditure arrears at end-2008 was calculated at GHф1.1 billion (Table below). In 2009, arrears to domestic suppliers of goods and services were settled amounting to $\mathrm{GH} \phi 0.6$ billion. At the same time, reflecting revenue shortfalls and expenditure pressures, new payments arrears amounting to GHф0.9 billion (4.2 percent of GDP) were accumulated in 2009, of which more than half represented arrears to governmental statutory funds. This increased the stock of arrears at end-2009 to GHф1.4 billion.

Outstanding Arrears, 2008-09

\begin{tabular}{lcccc}
\hline & \multicolumn{2}{c}{$\underline{\text { GHф millions }}$} & \multicolumn{2}{c}{ Percent of GDP } \\
& 2008 & 2009 & 2008 & 2009 \\
\hline Domestic suppliers & 830 & 855 & 4.7 & 3.9 \\
Statutory funds & $\underline{301}$ & $\underline{574}$ & $\underline{1.7}$ & $\underline{2.6}$ \\
Total & 1,132 & 1,429 & 6.4 & 6.5 \\
\hline
\end{tabular}

\section{Financing and Public Debt}

8. Consistent with the efforts to limit the fiscal deficit, the program limits on net domestic financing were met with a small margin during 2009 (Table 1). Public debt increased by about $2 \frac{1}{2}$ percentage points of GDP during 2009. This increase was smaller than earlier projected, reflecting currency appreciation in late-2009 which reduced foreign debt relative to nominal GDP, and delays in some external borrowing. New external borrowing was mainly long term in nature and on concessional terms. Nonconcessional borrowing under the ECF arrangement through March 2010 was limited to the take-over by

\footnotetext{
${ }^{2}$ Transfers to statutory funds are earmarked through legislation, and comprise specified shares of selected revenue collections. The funds experiencing reduced transfers comprise the Social Security Fund, the National Health Fund, the Ghana Education Trust Fund, and the District Assemblies Common Fund.
} 
the government of a $\$ 100$ million obligation of the state oil company, Ghana National Petroleum Company (GNPC). The government regarded this as restructuring of public debt inherited from the previous administration. However, Fund staff has concluded that it breached the limit under the ECF arrangement on contracting or guaranteeing new external nonconcessional debt (Table 1).

\section{Monetary and Financial Sector Developments}

9. Monetary policy continued to be guided by Bank of Ghana's inflation targeting framework during 2009. Reflecting a tighter monetary policy stance in 2008 and early 2009, private credit growth slowed sharply. As inflationary pressures eased, the BoG reduced its policy interest rate starting in late-2009. The program ceilings on net domestic assets (NDA) of the BoG have been met with large margins (Table 1). Broad money growth slightly exceeded program projections in 2009, albeit slowing from the 2008 growth rate, as net foreign assets rose in late-2009, boosted by a strong balance of payments.

10. The banking system weathered the global financial crisis and economic slowdown in 2009 relatively well, although risks to financial stability have increased. Nonperforming loans (NPLs) rose sharply to 20 percent in February 2010 from 7.7 percent in 2008, largely reflecting domestic factors, notably government expenditure arrears and impaired loans to energy sector utilities. The banking system is generally well capitalized, liquid, ${ }^{3}$ and profitable, though there is substantial variation across banks. Credit performance problems of the Tema Oil Refinery have been particularly problematic for the Ghana Commercial Bank (see below).

\section{E. External Sector}

11. The balance of payments in 2009 recorded the largest surplus in a decade. The current account improved substantially on account of strong exports and a fall in imports. The former was the result of favorable trends in cocoa and gold prices, while the latter reflected tighter fiscal and monetary policies, slowing economic growth, and a more depreciated exchange rate. The stronger current account more than offset a slight deterioration in the financial account. While the recent SDR allocations and foreign bank recapitalization contributed positively to the financial account, this was partly offset by repayment of corporate credit lines. The improved external performance contributed to an appreciation of the cedi against the U.S. dollar since July 2009, as well as an increase in Ghana's net international reserves of $\$ 1.2$ billion during 2009, compared to a projected decline of $\$ 404$ million under the program.

\footnotetext{
${ }^{3}$ The required increase in foreign commercial banks' minimum capital to GHф60 million by the end of 2009 has been a source of new liquidity.
} 


\section{F. Energy Sector Utilities}

12. The government is working to address domestic bank debts of the state oil refinery and electricity sector utilities amounting to more than 8 percent of GDP. These represent quasi-fiscal liabilities, adding to the public debt burden discussed above.

13. Although refined petroleum product prices have been adjusted to reflect trends in market costs under the ECF arrangement, under pricing of refined products in 2007-08 resulted in debts by the state oil refinery and other energy importers to the Ghana Commercial Bank (GCB) that are not being serviced amounting to about 5 percent of GDP. These liabilities have created asset quality and liquidity problems for GCB.

14. Electricity sector tariffs have not been adjusted since late 2007. Large losses were made in 2008 as oil prices rose, and losses have reemerged in 2010 with the resumed strength of oil prices. At end-2009, the bank debts of the electricity utilities were equivalent to more than 3 percent of GDP. An application to raise the electricity tariff has been submitted to the Public Utilities Regulatory Commission (PURC), the agency responsible for recommending tariff changes. The PURC is conducting stakeholder consultations ahead of reaching a decision.

\section{Ghana's Stabilization and Reform Program}

\section{A. Macroeconomic Framework for 2010 and the Medium Term}

15. Outlook for 2010. Real GDP growth is expected to strengthen moderately in 2010, reflecting strong gold and cocoa exports and a recovery in business confidence as oil production approaches. The year-end inflation target remains unchanged at 9.2 percent. The current account deficit is projected to rise to 12.1 percent of GDP in 2010, but reserve cover is expected to remain broadly stable at 2.9 months of imports of goods and services.

16. Medium-term outlook. In 2011, the economy is expected to benefit from the start of oil production. Real GDP growth is projected to surge to over 20 percent, the current account deficit to decline to 8 percent of GDP, and reserve cover to rise to the equivalent of 3.6 months of goods and services imports. Over the medium term, the non-oil economy is projected to achieve annual growth averaging about 6 percent, while inflation is projected to remain in the upper single-digit range.

17. Poverty reduction strategy. The process of updating Ghana's previous Poverty Reduction Strategy (GPRS-II) is the responsibility of the National Development Planning Commission (NDPC). The Commission's developmental and poverty reduction strategy for the period 2010-13 is being prepared for publication ahead of the September 2010 
Consultative Group meeting. The strategy benefited from earlier consultations with key stakeholders, and will be updated on an annual basis in light of changing policy priorities.

\section{B. Fiscal Policy in 2010 and the Medium Term}

\section{The 2010 budget}

18. Fiscal deficit target. Fiscal policy in 2010 aims to continue progress in restoring fiscal sustainability and macroeconomic stability. The 2010 budget targets a further reduction in the deficit to 8.0 percent of GDP. In 2011-12, the government intends to reduce the deficit to the 3-5 percent of GDP range.

19. Revenues and grants. On the revenue side, collections are projected to increase in 2010 by $3^{1 / 2}$ percentage points of GDP through higher mining royalties, a shift from specific to ad-valorem taxes on tobacco and drinks, higher fees and user charges, restoration of import duties on food products that were eliminated in 2008, strengthened enforcement of mobile phone taxation, elimination of import tax exemptions, new capital gains taxes, transfers of surplus income from the Ghana Cocoa Board and the Bank of Ghana, and strengthened tax administration (including creation of a single revenue authority and improved VAT enforcement).

20. Expenditure program. Expenditures are projected at 38.1 percent of GDP in 2010, similar to a "current policies" projection under the medium-term fiscal program developed in early-2009. Compared to the latter projection, interest costs have been revised up by more than 1 percentage point of GDP, reflecting the higher than expected cost of debt issuance in 2009 , while wage and salary costs have also been revised upwards, reflecting a larger wage increase in 2009 than in the baseline program. Against this, savings will be realized by the phased adjustment of electricity tariffs to cost recovery levels which will limit the need for budget subsidies, as well as through savings in the investment budget.

21. Risks and contingencies. The government has reviewed the 2010 fiscal projections carefully and expects to limit the fiscal deficit to 8 percent of GDP or lower with existing policies. Fiscal developments will be monitored on a monthly basis, with a special emphasis on revenue mobilization to ensure that the fiscal goals are met. The government stands ready to take whatever measures are needed to achieve its fiscal objective for 2010. In the event of an adverse fiscal shock, it would consider delaying some expenditures from 2010 to 2011, and would examine carefully options to strengthen revenue mobilization through improved administration, base broadening, and other regime changes. In the event of fiscal overperformance, available resources would be dedicated first to bringing forward the repayment of expenditure arrears.

22. Domestic arrears repayment strategy. With very limited resources to finance arrears clearance in 2010, provision has been made in the 2010 budget to repay arrears in the amount of GH $₫ 223$ million ( 0.9 percent of GDP). Priority is being given to repaying road 
contractors, to relieve pressures on these companies, as well as on their lending banks. Of the outstanding arrears to suppliers, a little over one quarter will be cleared with cash payments in 2010, with the remainder cleared in 2011-12. The government is exploring possible concessional financing options to bring forward the payment of these arrears.

23. In 2010 and beyond, the government has taken measures to further strengthen commitment controls to ensure that new payment arrears are not incurred. In particular, the government will remain current on transfers to the statutory funds from 2010, with arrears settled in 2011 to 2012. Nevertheless, these funds will experience large increases in cash flows in 2010 as funding returns to normal levels, and a further large increase in 2011-12 as arrears are settled.

24. Social safety nets. The government operates a number of programs to support the most vulnerable groups, including financial support for school fees and feeding, fertilizer subsidies for small-scale farmers, and reduced electricity tariffs for initial consumption amounts. In updating the government's poverty reduction strategy for the period 2010-13, the government is reviewing the complementarity and effectiveness of Ghana's various social safety nets. In the context of the envisaged adjustment of electricity tariffs, a decision will be made on whether additional support for low income groups is required, in part depending on the magnitude of the required tariff adjustment. At the same time, the government is working with development partners to review the current classification of poverty-reducing expenditure to ensure that this measure focuses on the key programs.

\section{Medium-term budget outlook}

25. The government is targeting a further reduction of the fiscal deficit through 201112 , to slow the growth of public debt and bring down the share of the budget devoted to debt service. Oil revenues will provide new fiscal space starting in 2011, but there will be many competing demands for these resources. These include the need to clear a residual stock of domestic expenditure arrears projected at about 5 percent of GDP at end-2010. In addition, even though every effort will be made to strengthen the non-oil budget through tight expenditure management and reinforced revenue administration, a portion of oil revenues may need to be dedicated to reducing the fiscal deficit. Until the outlook for oil incomes is better defined, and pending an assessment of revenue yields in 2010, the government intends to avoid committing to using oil revenues for specific projects for the near term. Notwithstanding this, a list of potential projects is being drawn up, and their respective contributions to Ghana's future development are being assessed, to guide any future scaling up of infrastructure and social spending. 


\section{Structural Fiscal Reforms ${ }^{4}$}

\section{Tax policy and revenue administration}

26. Tax policy reforms. The government has started a review of the nature and scope of tax exemptions and discretionary waivers (structural benchmark for September 2009; Table 3). A circular has been issued to all Ministries, Departments and Agencies (MDA) reconfirming that requests to parliament for approval of exemptions may be submitted only by the Ministry of Finance. A comprehensive and detailed review of remaining tax exemptions was delayed by work on the broader revenue administration and tax reform program (see below), and will be completed by end-September 2010. Consistent with IMF TA recommendations, excise taxes are now included in the base for VAT collections, and the three products subject to VAT zero-rating (pharmaceuticals, paper for books and newsprint, and agricultural machinery) have been converted to VAT exemptions. In the context of the 2010 budget, specific excise duties on tobacco products and beverages were replaced with ad valorem duties.

27. To strengthen revenue collections from the mining and minerals sector, the government increased the royalty rate in March 2010 from 3 to 5 percent. To reduce interest deductions the government will apply the provisions of the Internal Revenue Act on thin capitalization. Other elements of the fiscal regime for the mining sector that are being reconsidered include: (i) a five-year straight-line depreciation for capital; (ii) limiting to 5 years the provision for carry forward losses; (iii) extending the obligation to paying withholding taxes; (iv) requiring mines to declare at least 35 percent of their after tax profit as dividends; and (v) withdrawing the exemption to payment of property taxes. Going forward, the government is preparing a comprehensive program to strengthen other elements of tax policy (including on personal and corporate tax regimes), and may seek IMF assistance in preparing required amendments to tax legislation. In the year ahead, the government will also complete an assessment of the impact on households of increasing petroleum excise taxes. In addition, the government will substantially raise the VAT threshold in phases (in the first stage to GHф45,000; see Table 3).

28. Revenue administration. The government is modernizing revenue administration under a project managed by a newly formed Public Finance Management and Revenue Administration Steering Committee, chaired by a Deputy Minister of Finance. The three pre-existing revenue agencies have been brought under common management in a newly established Ghana Revenue Authority (GRA), with the new Commissioner General appointed in March 2010. By end-June, key management will be in place (commissioners and deputy commissioners), and the process of integrating junior staff into a common tax service will be underway.

\footnotetext{
${ }^{4}$ Structural benchmarks under the ECF arrangement are summarized in Table 3.
} 
29. In the year ahead, the focus in GRA will be on effectively integrating VAT and income taxation in a single domestic tax department, and adopting an organizational structure based on taxpayer size. About 350 companies will be covered by large taxpayer offices (LTOs), covering at least 70 percent of domestic tax collections. Coverage of the LTOs will be based on a minimum annual turnover of $\mathrm{GH} \not 3$ million, to be reviewed annually. Medium- and small taxpayer offices will also be established. In the first phase, one medium taxpayer office will be established in Accra to assess business processes. Small taxpayers (those falling below the threshold level) will be removed from the VAT registerthe government is currently assessing an appropriate tax regime for them, which will be adopted by end-June 2011 for introduction in the 2012 fiscal year.

\section{Public finance management}

30. Cash management. Since May 2009, cash management committee meetings have been held on a weekly basis, involving the Ministry of Finance, Controller and Accountant General's Department (CAGD), and BoG. The more frequent and more up-to-date monitoring of revenues, cash balances, and expenditures has proved critical in setting affordable monthly cash ceilings for spending units. Based on this monitoring, for example, provisions were not authorized in September-November 2009 for new domesticallyfinanced investment activities. As an interim measure, the cash management committee, using a module in the existing budget program, is strengthening data collection on all current commitments and contracts for capital expenditure. This system will be replaced by a fully developed commitment control system once the new Ghana Integrated Financial Management Information System (GIFMIS) becomes operational. To address the delays in transferring revenue collections by commercial banks to the government's accounts at the BoG, regular monthly meetings with commercial banks have been instituted, and a penalty rate, equal to the BoG's prime rate, is to be levied on all revenues not transferred within the required 48 hours. Going forward, the cash management committee will work with MDAs to strengthen monthly cash planning.

31. Treasury single account (TSA). Since May 2009, a number of ministerial, departmental, and agency accounts at the BoG have been closed, with a view to strengthening oversight over government cash balances. The remaining accounts are now monitored on a daily basis by the BoG to inform the work of the cash management committee. This is expected to result in some cost savings, with idle cash balances reallocated to finance expenditures, reducing the need for new domestic debt issuance. The TSA will become operational in three phases. In phase I, attention will be focused on linking the MoFEP and the CAGD to the government accounts at the BoG in Accra (about 1,400 accounts) - this is expected to be completed by mid-2010. Phase II, to be completed by January 2011, will entail extending the monitoring to all government accounts at the BoG (about 2,500 accounts), and Phase III, to be completed in 2012, will extend monitoring to government accounts at commercial banks. 
32. Financial management information system. The existing financial management information system which effectively stalled after being rolled out to 8 pilot ministries is being upgraded and expanded under the GIFMIS project. The project is being managed under the Steering Committee chaired by a Deputy Minister of Finance. An implementation strategy for GIFMIS is being developed with IMF technical assistance, based on a review of existing public financial management processes and guided by the systemic weaknesses identified in the recent Public Expenditure and Financial Assessment (PEFA) report. The implementation strategy will include a well formulated action plan and a timetable for the planned reforms to PFM processes, technical specifications and users' requirements of the new GIFMIS, hardware and software requirements, and plans for acquisition, pilot testing, and subsequent full roll out of the new system. This strategy will be finalized by mid-2010, assuming good progress in agreeing technical assistance and financing with the World Bank and other development partners.

33. Phase I of the re-launched public financial management reform program (to March 2011) will entail refining the budget process and MTEF, reforming budget execution and the chart of accounts, and testing the new integrated financial information system-first through in house testing, followed by a roll-out to 14 MDAs. During 2011-13, the updated PFM framework, including GIFMIS, will be extended to all remaining MDAs.

34. Learning from the former stalled roll-out of management information systems, the GIFMIS focuses on in-house staff, rather than long-term consultants (as in the past), which will ensure retention of key skills. The project is also being led by users, rather than by IT professionals, with involvement of affected government units from the outset in the project steering committee. Experience with the intensified cash management procedures noted above has also highlighted the need for a comprehensive financial management tool. Funding will be a challenge, but the government has received commitments from a number of development partners, in addition to funding for a financial management advisor.

\section{Oil revenue management}

35. The government is committed to establishing a transparent framework for managing petroleum and gas revenues. Drawing on international experience, a draft Petroleum Revenue Management Bill has been prepared. Receipts will be managed through a dedicated Petroleum Account, to be established at the Bank of Ghana, with full fiscal reporting to Parliament and the public, subject to stringent requirements for auditing of account transactions. The proposals envisage saving part of revenues in a "fund for future generations," with a second part accumulated for use in smoothing expenditures in the face of commodity price or production shocks. National consultations on the draft bill have been launched. Based on these consultations and after cabinet approval, the bill will be submitted to parliament by December 2010. In addition, a Petroleum Regulatory Authority bill will be submitted to parliament for its session starting September 2010. 


\section{Public sector reform and payroll management}

36. The headcount of the 283 thousand staff of the Public Education Sector was conducted in July-August 2009, with data collected from nearly 20 thousand educational establishments. Following cross-checks conducted through March 2010, and an opportunity to appeal, salary payments for apparent ghost workers have been suspended starting in April 2010. Reflecting good progress on this headcount, similar audits will be launched for other ministries (other than the health service, which was covered in late 2007), to be completed by end-June 2011 .

37. Progress in migrating all of the 119 subvented agencies to the Integrated Personnel and Payroll Database has been slow. The deadline for full migration by end-September 2009 was missed due to inadequate funding for software and consultants and as a result of pushback from some agencies. By end-March 2010, the government had migrated 79 agencies onto the computerized payroll database. Data for a further 28 agencies, representing tertiary educational institutions, have been received; data verification for these agencies is being completed, and migration is expected to be completed by end-July 2010 . The remaining 12 agencies, other than those in the security sector where personnel records are good, will be addressed by July 2010. The current stand-alone payroll database will be integrated and upgraded into the GIFMIS once roll-out of the latter has been completed. Pending this integration, for agencies already on the payroll database, new recruitment is verified by the CAGD on a continuous basis to ensure appropriate budget authorization.

\section{Energy sector reforms}

38. Electricity sector. Following finalization of a World Bank-supported study, government adopted a comprehensive financial restructuring and recovery plan for the electricity sector. The key elements of this plan are: (i) an average increase in electricity tariffs by 33 percent by no later than June 1, 2010 (prior action for the first and second reviews under the ECF arrangement); (ii) implementation of actions to strengthen revenue collection by the electricity sector public utilities; and (iii) adoption of a plan to restructure the balance sheets of the utilities during 2010-11. Any remaining shortfall relative to full cost recovery, if needed, will be closed by a further tariff adjustment in October 2010. The required power subsidy in 2010 is estimated at GHф358 million, and has been provided for in the revised budget estimates under the program. Going forward, tariffs will be subject to quarterly reviews to ensure continued cost recovery.

39. Petroleum products. The administered price ceilings for refined petroleum products remain subject to bi-weekly review. However, to smooth petroleum price adjustments, the government has decided to purchase call options, costed at up to 0.3 percent of GDP. A Risk Management Committee has been appointed to manage the government's hedging policy. The debts of TOR to banks and suppliers will be cleared by the government during 2010, while respecting fiscal and other limits under the ECF arrangement. A strategy for restoring 
TOR to financial and commercial viability will be developed by end-year; World Bank support for this is being sought.

\section{Public Debt Management}

40. While grant financing and concessional loan financing will constitute the core component of external support in the near future, nonconcessional financing will be used for projects contracted or guaranteed by the government where there is no scope for concessional or grant financing, the impact on debt sustainability is manageable, and project evaluations show a high rate of social or economic return. The ECF arrangement previously provided for public guarantees of up to $\$ 300$ million for nonconcessional borrowing by GNPC to participate in the first stage of a program to exploit gas deposits. This borrowing facility has not yet been used, and GNPC is seeking to arrange the needed financing without government guarantees. In light of this, the government requests that the ceiling for GNPC be reduced to $\$ 200$ million to make way for other priority projects. Specifically, projects to re-equip the fire service and to strengthen coastal protection in the Ada area have high calculated rates of social and economic return, but concessional financing is not available to cover the combined cost of $\$ 150$ million. The government has also committed $\$ 100$ million to the repayment of a loan related to the purchase of crude oil and requests the accommodation within the program of a further \$200 million of nonconcessional debt that could be contracted or guaranteed without prior authorization under the ECF arrangement. This is consistent with an unchanged overall risk vulnerability assessment.

41. A number of reforms are being introduced to further strengthen debt management, supported by technical assistance provided by the IMF and World Bank.

- Debt limits under the ECF arrangement will be extended to cover the external nonconcessional borrowing of only five specific energy-related state-owned enterprises. ${ }^{5}$ The coverage will be extended to other SOEs, as the government's capacity to monitor the external nonconcessional borrowing is strengthened.

- An explicit debt management strategy will be adopted and published by end-2010, establishing clear objectives for debt management in terms of the cost and risk of the debt portfolio, and identifying potential funding sources. The government envisions that the adoption of new financial instruments may require changes in the relevant legislation. Annual reporting to parliament will continue.

\footnotetext{
${ }^{5}$ The Tema Oil Refinery (TOR), Ghana National Petroleum Corporation (GNPC), Bulk Oil Storage and Transport Corporation (BOST), Volta River Authority (VRA), and Electricity Company of Ghana (ECG). The debt limits would exclude normal import-related credits and pre-export financing.
} 
- All public sector external debt contracts will be monitored closely by the Ministry of Finance's Debt Management Division.

- $\quad$ Public investment projects being considered for nonconcessional external loan financing will be subject to clearly defined framework for appraising their benefits and prioritizing across projects to ensure consistency with the government's developmental priorities. Guidelines laying out this process will be developed by the Ministry of Finance and submitted to Cabinet for approval by end-December 2010.

\section{Monetary and Exchange Rate Policy}

42. The BoG aims to bring inflation down to single digit level by the end of 2010, a process that has been helped by the recent currency stability. Against this, electricity tariffs will rise substantially in the coming months and the domestic and global economies are recovering. The BoG stands ready to tighten monetary conditions, if necessary, to ensure that its inflation target is achieved.

43. The BoG will continue to maintain a flexible exchange rate regime. Notwithstanding this, and while allowing some currency appreciation, it has used the opportunity provided by the strong balance of payments position in late 2009 to strengthen its international reserve position. The liquidity impact of any reserve accumulation will be monitored closely. If the balance of payments continues to see strong inflows, the BoG will respond consistently with its inflation targeting framework.

\section{Financial sector issues}

44. The Bank of Ghana is further strengthening its risk-based banking supervision capacity. Technical assistance is being provided by the Office of the Superintendent of Financial Institutions (OSFI) of Canada, including on preparation for Basel II. As part of this program, the technical unit of the banking supervision department is being strengthened by recruiting staff with analytical, IT, and other special skills. A program for building capacity in banking supervision will be developed as part of a broader modernization effort following the mission for the Financial Stability Assessment Program (FSAP) update around mid-2010. The BoG is also working with commercial banks to encourage them to update their own risk management capacity. The BoG has signed a memorandum of understanding with the central banks of the West African Monetary Zone to pave the way for strengthened cross-border supervision. The increased minimum operating capital has resulted in substantial additional liquidity for some banks, creating scope for credit expansion. The BoG will monitor banks experiencing rapid credit expansion to ensure that lending standards are maintained.

45. The situation of the Ghana Commercial Bank (GCB) is being given close attention, given its exposure to the financially illiquid state oil refinery. As a first step, government issued debt in March-April 2010 to improve GCB's liquidity, and by end-July 2010, a full 
strategy will be developed for adequately strengthening GCB's balance sheet, drawing on advice from an IMF mission in April/May 2010. Policies will also be developed for the design and application of appropriate depositor and exposure concentration benchmarks for the full banking industry.

\section{Program Design and Monitoring}

46. Based on the government's policies described in this memorandum, the government requests access to the second and third disbursement following completion of the first and second reviews under the ECF arrangement as summarized in Table 4. Looking ahead, the government is committed to meeting the quantitative macroeconomic targets and implementing the structural reforms highlighted as structural benchmarks detailed in the attached tables.

47. Quantitative performance under the ECF arrangement through end-December 2009 is summarized in Table 1. Quantitative targets for the period through end-June 2011 are proposed in Table 2. The fourth and fifth reviews under the ECF program are expected to be completed by end-June and end-December 2011, respectively. Consistent with the government's intention to sustain poverty-reducing spending during its program of economic stabilization and reform, an indicative floor for such spending will be adopted starting from end-June 2010 (Table 2). A new limit has also been proposed for the outstanding stock of domestic arrears, consistent with the government's arrears clearance strategy.

48. Structural benchmarks under the program through end-June 2011 are presented in Table 3. The focus of these benchmarks is on strengthening revenue administration, public expenditure management, public debt management, pay and payroll management, and costrecovery energy pricing.

\section{Macroeconomic monitoring}

49. Continuing efforts are needed to strengthen the macroeconomic database. In that connection, the Ghana Statistical Services (GSS) has launched the Ghana Statistical Development Plan (GSDP). Under the plan, the GSS aims to rebase the national accounts from 1993 to 2006 weights and to produce quarterly national accounts data by May 2010. The GSDP also aims at improving the Ghana Living Standards Survey (GLSS) and producing the survey on a four-yearly basis. The GSS is being supported in these efforts by financing and technical assistance from development partners. 
Table 1. Ghana: Quantitative Program Targets (December 2008 - December 2009) (Cumulative from the beginning of calendar year, unless otherwise indicated)

\begin{tabular}{|c|c|c|c|c|c|c|c|c|c|c|c|c|}
\hline & & \multirow{3}{*}{$\begin{array}{l}2008 \\
\text { Dec. } \\
\text { Act. }\end{array}$} & \multicolumn{10}{|c|}{2009} \\
\hline & & & \multirow{2}{*}{$\begin{array}{l}\text { Mar. } \\
\text { Act. }\end{array}$} & \multirow{2}{*}{$\begin{array}{l}\text { Jun. } \\
\text { Act. }\end{array}$} & \multicolumn{4}{|c|}{ Sep. (MEFP, 7/09) } & \multicolumn{4}{|c|}{$\begin{array}{l}\text { Dec. (MEFP, 7/09) } \\
\end{array}$} \\
\hline & & & & & Prog. $^{2}$ & $\begin{array}{r}\text { Adjusted } \\
\text { Target } \\
\end{array}$ & Act. & $\begin{array}{r}\text { Met or } \\
\text { Not met }\end{array}$ & Prog. $^{2}$ & $\begin{array}{r}\text { Adjusted } \\
\text { Target } \\
\end{array}$ & Prel. & $\begin{array}{r}\text { Met or } \\
\text { Not met }\end{array}$ \\
\hline \multirow[t]{3}{*}{ I } & Quantitative Performance Criteria & & & & & & & & & & & \\
\hline & Overall fiscal deficit of the government (ceiling; in millions of cedis) & 2,558 & 344 & 922 & 1,470 & 1,459 & 1,629 & Not met & 2,034 & 2,249 & 2,131 & Met \\
\hline & Net international reserves of the Bank of Ghana (floor; millions of U.S. dollars) & 1,301 & -404 & -626 & -728 & -143 & -30 & Met & -404 & 49 & 1,159 & Met \\
\hline \multirow[t]{5}{*}{ II } & Continuous Performance Criteria (cumulative from July 15, 2009) & & & & & & & & & & & \\
\hline & Non-accumulation of external arrears (ceiling; millions of U.S. dollars) & 0 & 0 & 0 & 0 & 0 & 0 & Met & 0 & 0 & 0 & Met \\
\hline & Contracting or guaranteeing of new medium-to-long-term nonconcessional external debt (ceiling; US\$ millions) & $\ldots$ & $\ldots$ & $\ldots$ & 300 & 300 & 0 & & 300 & 300 & 100 & \\
\hline & Oil and gas sector & $\ldots$ & $\ldots$ & $\ldots$ & 300 & 300 & 0 & Met & 300 & 300 & 0 & Met \\
\hline & Other sectors & $\ldots$ & $\ldots$ & $\ldots$ & 0 & 0 & 0 & Met & 0 & 0 & 100 & Not met \\
\hline \multirow[t]{7}{*}{ III } & Inflation Consultation & & & & & & & & & & & \\
\hline & Twelve-month consumer price inflation (percent) & & & & & & & & & & & \\
\hline & Outer band (upper limit) & $\ldots$ & $\ldots$ & $\ldots$ & 19.5 & 19.5 & & & 17.6 & 17.6 & & \\
\hline & Inner band (upper limit) & & & & 18.5 & 18.5 & & & 16.6 & 16.6 & & \\
\hline & Central target rate of inflation & 18.1 & 20.5 & 20.7 & 16.5 & 16.5 & 18.4 & Met & 14.6 & 14.6 & 16.0 & Met \\
\hline & Inner band (lower limit) & $\ldots$ & & $\ldots$ & 14.5 & 14.5 & & & 12.6 & 12.6 & & \\
\hline & Outer band (lower limit) & $\ldots$ & & $\ldots$ & 13.5 & 13.5 & & & 11.6 & 11.6 & & \\
\hline \multirow[t]{3}{*}{ IV } & Indicative Targets & & & & & & & & & & & \\
\hline & Net domestic financing of the government (ceiling, in millions of cedis) & 1,735 & 243 & 674 & 828 & 903 & 826 & Met & 1,033 & 1,108 & 1,042 & Met \\
\hline & Net domestic assets of the Bank of Ghana (ceiling; millions of cedis) ${ }^{4}$ & 64 & 331 & 698 & 990 & 990 & 462 & Met & 605 & 605 & -342 & Met \\
\hline
\end{tabular}

Sources: Ghanaian authorities, and IMF staff estimates and projections.

All variables and adjustors the targets are defined in the attached Technical Memorandum of Understanding (TMU).

${ }^{2}$ Performance criterion.

${ }^{3}$ September and December 2009 targets after adjustment for SDR allocation.

${ }^{4}$ The program ceiling has been adjusted to reflect the reclassification of SDR liabilities in the accounts of the Bank of Ghana as long-term foreign liabilities. 
Table 2. Ghana: Quantitative Program Targets (December 2009 - June 2011) ${ }^{1}$

(Cumulative from the beginning of calendar year, unless otherwise indicated)

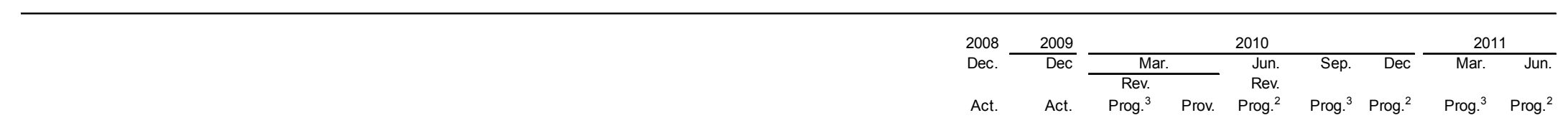

I Quantitative Performance Criteria

Overall fiscal deficit of the government (ceiling; in millions of cedis)

Net international reserves of the Bank of Ghana (floor; millions of U.S. dollars) ${ }^{4}$

Net change in the stock of domestic arrears (celing, in millions of cedis)

II Continuous Performance Criteria (cumulative from July 15, 2009)

Non-accumulation of external arrears (ceiling; millions of U.S. dollars)

Contracting or guaranteeing of new medium-to-long-term nonconcessional external debt (ceiling; US $\$$ millions)

Oil and gas sector ${ }^{6}$

Fire-fighting equipment

Ada coastal protection project

Any sectors

$\begin{array}{rrrrrrrrr}2,558 & 2,131 & 500 & \ldots & 1,186 & 1,958 & 2,077 & 444 & 746 \\ 1,301 & 2,459 & -83 & \ldots & -15 & -98 & 315 & 104 & 207 \\ & & & & & & & & \\ & 1,429 & -28 & \ldots & -55 & -83 & -110 & -257 & -405 \\ & & & & & & & & \\ & & & & & & & & \\ 0 & 0 & 0 & \ldots & 0 & 0 & 0 & 0 & 0 \\ & & & & & & & & \\ \ldots & 100.0 & 300.0 & \ldots & 649.1 & 649.1 & 649.1 & 649.1 & 649.1 \\ \ldots & 0.0 & 300.0 & \ldots & 200.0 & 200.0 & 200.0 & 200.0 & 200.0 \\ & \ldots & 0.0 & \ldots & 49.1 & 49.1 & 49.1 & 49.1 & 49.1 \\ & \ldots . & 0.0 & \ldots & 100.0 & 100.0 & 100.0 & 100.0 & 100.0 \\ \ldots & 100.0 & 0.0 & \ldots & 300.0 & 300.0 & 300.0 & 300.0 & 300.0\end{array}$

III Inflation Consultation

Twelve-month consumer price inflation (percent)

Outer band (upper limit)

Inner band (upper limit)

Central target rate of inflation

Inner band (lower limit)

Outer band (lower limit)

\begin{tabular}{|c|c|c|c|c|c|c|c|}
\hline$\cdots$ & & 15.2 & & 12.7 & 12.5 & 12.5 & 12.0 \\
\hline & & 14.2 & & 11.7 & 11.5 & 11.5 & 11.0 \\
\hline 18.1 & 16.0 & 12.2 & 13.3 & 9.7 & 9.5 & 9.5 & 9.0 \\
\hline & & 10.2 & $\cdots$ & 7.7 & 7.5 & 7.5 & 7.0 \\
\hline$\ldots$ & & 9.2 & $\ldots$ & 6.7 & 6.5 & 6.5 & 6.0 \\
\hline
\end{tabular}

\section{Indicative Targets}

Net domestic financing of the government (ceiling, in millions of cedis)

Net domestic assets of the Bank of Ghana (ceiling; millions of cedis) ${ }^{4}$

Poverty-reducing budget expenditures (floor; in millions of cedis)

$\begin{array}{rrrrrrrrr}1,735 & 1,022 & 875 & \ldots & 1,234 & 1,650 & 1,688 & 385 & 471 \\ -76 & -278 & -103 & -165 & -278 & -8 & 50 & -350 & -451 \\ 1,687 & 1,856 & 444 & \ldots & 820 & 1,463 & 2,106 & 554 & 1110\end{array}$

Sources: Ghanaian authorities, and IMF staff estimates and projections.

${ }^{1}$ All variables and adjustors the targets are defined in the attached Technical Memorandum of Understanding (TMU).

Performance criterion.

3 Indicative target.

${ }^{4}$ December 2009 target after adjustment for SDR allocation. March 2010 indicative ceiling from the original July 2009 ECF program.

${ }^{5}$ Cumulative from December 31, 2009. The end-of-period stock is GHc 1,429 million.

${ }^{6}$ For the GNPC to finance oil and gas exploration and production projects in Ghana and to acquire equity stakes in companies

undertaking oil and gas exploration and production in Ghana. 
Table 3. Ghana: Prior Actions and Structural Benchmarks Under ECF Arrangement, 2009-11

\begin{tabular}{|c|c|c|c|}
\hline Measures & Timing & Implementation status & Macroeconomic rationale \\
\hline \multicolumn{4}{|l|}{ 1. Tax policy and revenue administration } \\
\hline $\begin{array}{l}\text { - Complete comprehensive reviews of } \\
\text { zero-rated VAT items and the nature } \\
\text { and scope of tax exemptions and } \\
\text { discretionary waivers. }\end{array}$ & $\begin{array}{l}\text { End-Sep. } \\
2009\end{array}$ & $\begin{array}{l}\text { Delayed. A number of exemptions have been } \\
\text { eliminated (MEFP para. 26). A full review of the } \\
\text { extent, nature, and scope for scaling back exemptions } \\
\text { has been initiated, and will be completed by end- } \\
\text { September } 2010 \text { (structural benchmark). }\end{array}$ & $\begin{array}{l}\text { Strengthen revenue mobilization as } \\
\text { part of the fiscal consolidation } \\
\text { strategy. }\end{array}$ \\
\hline $\begin{array}{l}\text { - Cabinet approval of a modernization } \\
\text { strategy for revenue administration. }\end{array}$ & $\begin{array}{l}\text { End-Dec. } \\
2009\end{array}$ & $\begin{array}{l}\text { Implemented. Presidential assent to legislation } \\
\text { establishing the Ghana Revenue Authority was given at } \\
\text { end-2009. }\end{array}$ & As above. \\
\hline $\begin{array}{l}\text { - Appoint senior GRA management } \\
\text { (commissioners and deputy } \\
\text { commissioners) and adopt criteria to } \\
\text { ensure that the Large Taxpayer Office } \\
\text { covers businesses accounting for at } \\
\text { least } 70 \text { percent of total tax revenues. }\end{array}$ & $\begin{array}{l}\text { End-Jun. } \\
2010\end{array}$ & New benchmark (MEFP para. 28) & As above. \\
\hline $\begin{array}{l}\text { - Increase the VAT threshold to no } \\
\text { less than GH } \varnothing 45,000 \text { as the first stage } \\
\text { of a phased increase. }\end{array}$ & $\begin{array}{l}\text { End-Dec. } \\
2010\end{array}$ & New benchmark (MEFP para. 27) & As above. \\
\hline $\begin{array}{l}\text { - Adopt a tax regime for small } \\
\text { business taxpayers for introduction in } \\
\text { the } 2012 \text { fiscal year. }\end{array}$ & $\begin{array}{l}\text { End-Jun } \\
2011\end{array}$ & New benchmark (MEFP para. 29) & As above. \\
\hline \multicolumn{4}{|l|}{ 2. Public expenditure management } \\
\hline $\begin{array}{l}\text { - Review the effectiveness of the } \\
\text { existing budget management } \\
\text { information system, and decide on } \\
\text { whether it should be modernized or } \\
\text { replaced. }\end{array}$ & $\begin{array}{l}\text { End-Dec. } \\
2009\end{array}$ & $\begin{array}{l}\text { Implemented early. The existing system will be } \\
\text { upgraded through new software and hardware and } \\
\text { additional modules. A project implementation } \\
\text { committee has been established, chaired by the Deputy } \\
\text { Minister of Finance. Funding is being identified. }\end{array}$ & $\begin{array}{l}\text { Strengthen monitoring and control } \\
\text { of budget execution. }\end{array}$ \\
\hline $\begin{array}{l}\text { - Roll out GIMFIS to } 14 \text { selected pilot } \\
\text { MDAs. }\end{array}$ & $\begin{array}{l}\text { End-March } \\
2011\end{array}$ & New benchmark & As above. \\
\hline
\end{tabular}




\begin{tabular}{|c|c|c|c|}
\hline \multicolumn{4}{|l|}{ 3. Public Debt Management } \\
\hline $\begin{array}{l}\text { - Develop and publish a debt } \\
\text { management strategy for Ghana. }\end{array}$ & $\begin{array}{l}\text { End-Dec. } \\
2010\end{array}$ & New benchmark (MEFP para. 41) & $\begin{array}{l}\text { To support the achievement of } \\
\text { public debt sustainability. }\end{array}$ \\
\hline $\begin{array}{l}\text { - Develop and submit to Cabinet for } \\
\text { approval procedures for appraisal and } \\
\text { selection of public investment projects } \\
\text { considered for external } \\
\text { nonconcessional loans. }\end{array}$ & $\begin{array}{l}\text { End-Dec } \\
2010 .\end{array}$ & New benchmark (MEFP para. 41) & As above. \\
\hline \multicolumn{4}{|c|}{ 4. Public sector reform and payroll management } \\
\hline $\begin{array}{l}\text { - Steps to strengthen oversight and } \\
\text { control of public service recruitment } \\
\text { and staffing. }\end{array}$ & $\begin{array}{l}\text { End-Sep. } \\
2009\end{array}$ & $\begin{array}{l}\text { Partially met. The selective hiring freeze remains in } \\
\text { place and new recruits by agencies included on the } \\
\text { payroll database are audited on a monthly basis to } \\
\text { verify consistency with budget provisions. The } \\
\text { headcount of the Ghana Education Service was } \\
\text { conducted by end-August. Only limited progress was } \\
\text { made in the planned migration of all subvented } \\
\text { agencies to the automated payroll database by end- } \\
\text { September 2009, largely reflecting inadequate funding } \\
\text { for software and consultants. }\end{array}$ & $\begin{array}{l}\text { To strengthen oversight and } \\
\text { control of the high and growing } \\
\text { public payroll. }\end{array}$ \\
\hline $\begin{array}{l}\text { - Establish institutional responsibility } \\
\text { for the restructuring, } \\
\text { commercialization, or liquidation of } \\
\text { subvented agencies. }\end{array}$ & $\begin{array}{l}\text { End-Dec. } \\
2009\end{array}$ & $\begin{array}{l}\text { Implemented early. The Ministry for the Public Sector } \\
\text { has been appointed to head this project. }\end{array}$ & $\begin{array}{l}\text { To promote fiscal savings by } \\
\text { rationalizing subvented agency } \\
\text { numbers. }\end{array}$ \\
\hline $\begin{array}{l}\text { - Migrate to the automated payroll } \\
\text { system (IPPD2/3) all remaining non- } \\
\text { security subvented agencies. }\end{array}$ & $\begin{array}{l}\text { End-July } \\
2010\end{array}$ & $\begin{array}{l}\text { Revision of the earlier September } 2009 \text { benchmark } \\
\text { (see above). }\end{array}$ & As above. \\
\hline
\end{tabular}




\begin{tabular}{|c|c|c|c|}
\hline $\begin{array}{l}\text { - Submit for cabinet approval list of } \\
\text { subvented agencies to be } \\
\text { commercialized or liquidated. }\end{array}$ & $\begin{array}{l}\text { End-Dec } \\
2010 .\end{array}$ & New benchmark. & As above. \\
\hline $\begin{array}{l}\text { - Complete pay comparability survey } \\
\text { for public and private sectors for a } \\
\text { sizeable number of public sector career } \\
\text { streams. }\end{array}$ & $\begin{array}{l}\text { End-June } \\
2011 .\end{array}$ & New benchmark. & As above. \\
\hline \multicolumn{4}{|l|}{ 5. Energy sector management } \\
\hline $\begin{array}{l}\text { - New electricity tariff structure, with } \\
\text { the average increased by at least } 33 \\
\text { percent, will become effective no later } \\
\text { than June } 1,2010 \text {, as part of phased } \\
\text { approach to bring the average tariff to } \\
\text { cost recovery levels. }\end{array}$ & $\begin{array}{l}2^{\text {nd }} \mathrm{ECF} \\
\text { review. }\end{array}$ & Prior action for $2^{\text {nd }}$ ECF review. & $\begin{array}{l}\text { To avoid energy sector SOE losses, } \\
\text { which have historically posed } \\
\text { serious burdens on the budget. }\end{array}$ \\
\hline $\begin{array}{l}\text { Implement additional required } \\
\text { increase in electricity tariffs to bring } \\
\text { the average tariff to cost recovery } \\
\text { levels. }\end{array}$ & $\begin{array}{l}3^{\text {rd }} \mathrm{ECF} \\
\text { review. }\end{array}$ & New benchmark (MEFP para. 38) & As above. \\
\hline $\begin{array}{l}\text { - Submit to parliament legislation } \\
\text { establishing rules for oil and gas } \\
\text { revenue management, establishing } \\
\text { clear rules for the transparent reporting } \\
\text { of revenues and spending in the budget, } \\
\text { rules governing possible revenue } \\
\text { retention by GNPC, and audit } \\
\text { requirements. }\end{array}$ & $\begin{array}{l}\text { End-Dec } \\
2010\end{array}$ & New benchmark (MEFP para. 35) & $\begin{array}{l}\text { Ensure transparent and prudent } \\
\text { management of Ghana's oil } \\
\text { incomes. }\end{array}$ \\
\hline $\begin{array}{l}\text { - Develop strategy for restoring } \\
\text { financial and commercial viability to } \\
\text { Tema oil refinery. }\end{array}$ & $\begin{array}{l}\text { End-Dec } \\
2010 .\end{array}$ & New benchmark. & As above. \\
\hline
\end{tabular}




\section{Monetary and financial policy}

- Adoption and launch of program to strengthen communication of

End-Dec.

2009.

framework for inflation targeting and disinflation over program period.

- Develop strategy to fully strengthen Ghana Commercial Bank balance
Implemented early. A redesigned website to strengthen the communication of the Bank of Ghana's inflation targeting policy framework was launched in November 2009.

New benchmark.
To support the disinflation program.

To contribute to continued financial sector stability. 
Table 4. Ghana: Proposed Schedule of Disbursements under the ECF Arrangement, $2009-12^{1}$

\begin{tabular}{|c|c|c|}
\hline Amount & Date available & Condition necessary for disbursement \\
\hline SDR 67.65 million & July 15, 2009 & Disbursed on approval of ECF arrangement \\
\hline SDR 16.00 million $^{2}$ & Dec 15, 2009 & $\begin{array}{l}\text { Observance of the performance criteria for } \\
\text { September } 30,2009 \text {, and completion of the first review } \\
\text { under the arrangement. }\end{array}$ \\
\hline SDR 65.50 million $^{2 /}$ & March 15, 2010 & $\begin{array}{l}\text { Observance of the performance criteria for } \\
\text { December } 31,2009 \text {, and completion of the second } \\
\text { review under the arrangement. }\end{array}$ \\
\hline SDR 65.50 million $^{3}$ & $\begin{array}{l}\text { September } 15 \text {, } \\
2010\end{array}$ & $\begin{array}{l}\text { Observance of the performance criteria for } \\
\text { June } 30,2010 \text {, and completion of the third review under } \\
\text { the arrangement. }\end{array}$ \\
\hline SDR 43.20 million $^{4}$ & March 15, 2011 & $\begin{array}{l}\text { Observance of the performance criteria for } \\
\text { December } 31,2010 \text {, and completion of the fourth review } \\
\text { under the arrangement. }\end{array}$ \\
\hline SDR 43.20 million & $\begin{array}{l}\text { September } 15 \text {, } \\
2011\end{array}$ & $\begin{array}{l}\text { Observance of the performance criteria for } \\
\text { June } 30,2011 \text {, and completion of the fifth review under } \\
\text { the arrangement. }\end{array}$ \\
\hline SDR 43.20 million & March 15, 2012 & $\begin{array}{l}\text { Observance of the performance criteria for } \\
\text { December } 31,2011 \text {, and completion of the sixth review } \\
\text { under the arrangement. }\end{array}$ \\
\hline SDR 43.20 million & June 15, 2012 & $\begin{array}{l}\text { Observance of the performance criteria for } \\
\text { March } 31,2012 \text {, and completion of the seventh review } \\
\text { under the arrangement. }\end{array}$ \\
\hline
\end{tabular}

${ }^{1}$ In addition to the generally applicable conditions under the Extended Credit Facility arrangement.

${ }^{2}$ About $\$ 125$ million for the combined first and second ECF reviews, at a projected exchange rate of $\mathrm{SDR} 1=\$ 1.537$.

${ }^{3}$ About $\$ 100$ million, at a projected exchange rate of SDR $1=\$ 1.537$.

${ }^{4}$ About $\$ 66$ million, at a projected exchange rate of SDR1 $=\$ 1.537$. 
APPENDiX I-ATTACHMENT II

\section{TECHNiCAL MEMORANDUM OF UNDERSTANDing}

\section{Arrangement under the Extended Credit Facility June 2010-12}

1. This technical memorandum of understanding (TMU) defines the variables subject to quantitative targets (performance criteria and indicative targets), as specified in the Letter of Intent (LOI). It also describes the methods to be used to assess the program performance and the information requirements to ensure adequate monitoring of the targets. The authorities will consult with the Fund before modifying measures contained in this letter, or adopting new measures that would deviate from the goals of the program, and provide the Fund with the necessary information for program monitoring.

2. Program exchange rate: The exchange rates for the purpose of the program of the Ghanaian cedi $(\mathrm{GH} \phi)$ to the U.S. dollar will be GHф1.45 per US\$1, which is calculated as the average of buying and selling exchange rates reported by banks to the Bank of Ghana as of June 19, 2009. The exchange rates to other currencies will be calculated as the average of buying and selling exchange rates against the U.S. dollar as of June 19, 2009.

\section{Quantitative Program Indicators}

3. For program monitoring purposes, the performance criteria are set for end-June 2010, end-December 2010, and end-June 2011, while indicative targets are set for end-March, endSeptember 2010, and end-March 2011. Performance criteria, indicative targets, and adjusters are calculated as cumulative flows from the beginning of the calendar year, except for external nonconcessional debt, which is defined as in cumulative terms from July 1, 2009.

4. The performance criteria under the arrangement are:

- a ceiling on the overall fiscal deficit of the government, measured in terms of financing;

- a floor on the net international reserves of the Bank of Ghana;

- a ceiling on the net change in the stock of domestic arrears;

- a continuous zero ceiling for the accumulation of new external arrears; and

- a ceiling on the contracting or guaranteeing of new external nonconcessional debt

5. Indicative targets are established as:

- a ceiling on the net domestic financing of the government;

- a ceiling on the net domestic assets of the Bank of Ghana; and

- a floor on poverty-reducing government expenditures. 
6. A target is set for the twelve-month rate of consumer price inflation, with triggers on discussions or consultations with the Fund if inflation moves outside specified inner and outer bands.

\section{A. Government}

7. Definition: The government is defined as comprising the central government, all special funds (including the Education Trust Fund, the Road Fund, the District Assembly Common Fund, and the National Health Insurance Fund), and all subvented and other government agencies that are classified as government in the Bank of Ghana (BoG) Statement of Accounts (SOA). The Social Security and National Insurance Trust (SSNIT) and public enterprises, including Cocobod, are excluded from the definition of government

8. The fiscal deficit is measured as total financing extended to the government (as defined in paragraph 7 above), comprising the sum of net foreign borrowing (as defined in paragraph 12 below), net domestic financing (defined in paragraph 11 below), exceptional financing (including HIPC and MDRI relief against loan repayments falling due), and receipts from net divestitures.

9. Domestic payments arrears will be measured as the sum of two components. The first component, arrears to the government's statutory funds, represents any delay of more than one month in revenue transfers to these statutory fund, relative to the normal payment schedule (typically monthly or quarterly, and defined as a specific percentage of the previous month or quarter's revenue collections). ${ }^{1}$ The second component, arrears to contractors, is defined as payments that are due and not settled within 30 days after the end of the fiscal year. Net changes in the stock of arrears to contractors at end-March, June, and September are defined as the stock of arrears at the end of the previous fiscal year less the amounts settled during the current fiscal year. The end-December stock of arrears is measured as the end-year balance at the end of the previous fiscal year, minus amounts settled during the current year, plus the accumulation of new arrears to contractors in the current year (defined as payments outstanding for 30 days or more after the end of the current fiscal year). As fiscal monitoring systems are strengthened, the goal will be to also include arrears to contractors that accrue within a given year, measured at end-March, June, and September.

10. The government will continue to report poverty-related expenditures, including the use of funds from the enhanced Heavily Indebted Poor Countries (HIPC) Initiative. Budgeted poverty spending for these categories will be taken from each year's final appropriations bill and will include spending financed by the government or donors or from internally generated funds. Actual poverty-related spending will be identified using the last

\footnotetext{
${ }^{1}$ Transfers to the statutory funds are scheduled as follows: (i) District Assemblies Common Fund - quarterly, with a one-quarter lag; (ii) Social Security Fund, National Health Fund, Ghana Education Trust Fund, Road Fund, Petroleum-related Fund, - monthly, with a one-month lag.
} 
3 digits of the 15-digit chart of accounts of the CAGD's current NETS and the subcomponent that is financed through HIPC Initiative debt relief. This data will be supplemented with that proportion of transfers to the District Assembly Common Fund, the Ghana Educational Trust Fund, and the Road Fund, which the government considers as poverty-related. Accordingly, actual poverty spending will exclude some donor-supported expenditure not currently captured by the CAGD.

11. Net domestic financing of government is defined as the change in net credit to government by the banking system (i.e., the Bank of Ghana plus deposit money banks) plus the net change in holdings of treasury bills and other government securities by the nonbank sector, excluding divestiture receipts. Such credit will also exclude treasury bills issued for open market operation purposes from January 1, 2003 onward (the holdings of which are excluded from the BoG Treasury Department's Debt Registry of central government securities, and the proceeds of which are sterilized in deposits held as other BoG liabilities, as defined in the monetary template provided to the IMF on December 3, 2003).

12. Net foreign financing of government is defined as the sum of project and program loans by official donors, commercial external borrowing, minus amortization due.

13. Outstanding net credit to the government by the Bank of Ghana comprises the sum of claims on government (SOA codes 0401 and 050101-4), including overdrafts of the government with the BoG, less government deposits (1101 including the main HIPC Initiative receiving account, and 1202) as defined in the monetary template.

14. Outstanding net credit by deposit money banks comprises deposit money bank (DMB) holdings of government securities at cost of purchase value, as reported by the BoG Treasury Department's Debt Registry, plus overdrafts less government deposits as reported by DMBs in the revised BSD2 report forms (and defined in the Monetary Template), plus deferred accrued interest on their holdings of inflation-indexed bonds.

15. Nonbank financing is the difference between total net cash receipts to the treasury main cash account (issues/redemptions account when it becomes operational) from the sale/repurchase of government securities, less the corresponding net cash value received from the BoG and DMBs as indicated on the Debt Registry by holder at discount value, plus deferred accrued interest on their holdings of inflation-indexed bonds. For each test date, any adjustment by the BoG to the data reported by individual DMBs, on account of their misclassification of government or for other reasons, will be reported to the Fund.

\section{B. Consultation Mechanism on Inflation}

\section{The quarterly consultation band for the twelve-month rate of consumer price} inflation (as measured by the headline consumer price index (CPI) published by the Ghana Statistical Services) are specified in Tables 1 and 2 attached to the memorandum of economic and financial policies. Projected CPI for end-June 2010, end-December 2010, and end-June 
2011 will be subject to the consultation mechanism, while those for end-September 2010 and end-March 2011 are indicative targets.

17. When the observed year-on-year CPI inflation rate falls outside a specific band, this would trigger consultation with the Fund.

18. The authorities will complete consultation with the Executive Board of the Fund on the proposed policy response before requesting further purchases under the program when the observed year-on-year CPI inflation rate moves outside the outer band as specified for the end of each quarter in the above table. The authorities will not be able to request any further disbursements under the ECF arrangement if inflation moves outside of the outer band until the consultation with the Executive Board has taken place.

19. The authorities will conduct discussions with the Fund staff when the observed yearon-year CPI inflation rate falls outside the inner band as specified for the end of each quarter in the above table.

20. In line with our accountability principles, we are committed to report to the public the reasons for any breach of the outer bands, and our policy response.

\section{Bank of Ghana}

21. Net foreign assets are defined in the monetary survey as short- and long-term foreign assets minus liabilities of the BoG that are contracted with nonresidents. Short-term foreign assets include: monetary gold (valued at the spot market rate for gold, US\$/fine ounce, London), holdings of SDRs, reserve position and HIPC Initiative trust investment in the IMF, the HIPC Initiative Umbrella SDR account (all as reported by the IMF), foreign notes and travelers checks, foreign securities, positive balances with correspondent banks, and other positive short-term or time deposits. Short-term foreign liabilities include foreign currency liabilities contracted by the BoG at original maturities of one year or less (including overdrafts), outstanding liabilities to the IMF, and deposits of international institutions at the BoG. Long-term foreign assets and liabilities are comprised of: other foreign assets (BoG statement of accounts code 303), investments abroad (a subset of 60201), other long-term liabilities to nonresidents (a subset of 1103), and bilateral payment agreements (305). All values not in U.S. dollars are to be converted to U.S. dollars at the program exchange rate defined in paragraph 2. A more detailed listing of accounts to be included in the measure of net foreign assets is contained in the monetary template referred to in paragraph 14 above.

22. Net international reserves of the $\mathrm{BoG}$ are defined for program monitoring purposes and in the balance of payments as short-term foreign assets of the BoG, minus short-term external liabilities. To the extent that short-term foreign assets are not fully convertible external assets readily available to and controlled by the BoG (that is, they are pledged or otherwise encumbered external assets, including, but not limited to, the HIPC umbrella SDR account), they will be excluded from the definition of net international reserves. Net 
international reserves are also defined to include net swap transactions (receivable less payable) and exclude all positive foreign currency deposits at the BoG held by resident deposit money banks, public institutions, nonfinancial public enterprises, other financial institutions, and the private sector. All values not in U.S. dollars are to be converted to U.S. dollars at the program exchange rate defined in paragraph 2. A more detailed listing of accounts to be included in the measure of net international reserves is contained in the monetary template referred to in the paragraph 14 above.

23. Net domestic assets of the Bank of Ghana are defined as the difference between reserve money and net foreign assets of the BoG, excluding the HIPC Umbrella SDR account, converted from U.S. dollars to cedis at the program exchange rate.

\section{External Debt and Debt Service}

24. Nonconcessional medium- and long-term external debt is defined as debt to nonresidents contracted or guaranteed by the government (as defined in paragraph 7), the Bank of Ghana, and specific enterprises defined in paragraph 26 , with an original maturity of more than one year, provided that debt maturing within one year which has been extended beyond one year from its original date, pursuant to the contract which allows for maturity extension, would be considered medium to long term. Medium- and long-term external debt and its concessionality will be reported by the Aid and Debt Management Unit of the Ministry of Finance and Economic Planning, and will be measured in U.S. dollars at current exchange rates.

25. External payment arrears would accrue when undisputed interest or amortization payments of the government (as defined in paragraph 7) are not made within the terms of the contract.

\section{E. Ceiling on the Contracting or Guaranteeing of New Nonconcessional External Debt}

26. A ceiling applies to the contracting and guaranteeing by the government and the BoG, and the following public enterprises: (i) Tema Oil Refinery; (ii) Ghana National Petroleum Corporation; (iii) Bulk Oil Storage and Transport Corporation; (iv) Volta River Authority; and (v) Electricity Company of Ghana. The ceiling applies to debt and commitments contracted or guaranteed for which value has not yet been received. 
27. The definition of debt, for the purposes of the program, is set out in Point 9 of Executive Board Decision No. 6230-(79/140), as amended by Decision No 14416-(09/91, effective December 1, 2009). ${ }^{2}$

28. Excluded from the ceiling are (i) the use of Fund resources; (ii) lending from the World Bank, the African Development Bank, and the International Fund for Agricultural Development; (iii) concessional external debts; and (iv) any cedi-denominated treasury bills and government bonds, and BoG bills held by nonresidents.

29. For program purposes, a debt is concessional if it includes a grant element of at least 35 percent, calculated as follows: the grant element of a debt is the difference between the net present value (NPV) of debt and its nominal value, expressed as a percentage of the nominal value of the debt. The NPV of debt at the time of its contracting is calculated by discounting the future stream of payments of debt service due on this debt. The discount rates used for this purpose are the currency specific commercial interest reference rates (CIRRs), published by the Organization for Economic Cooperation Development (OECD). For debt with a maturity of at least 15 years, the ten-year-average CIRR will be used to calculate the NPV of debt and, hence, its grant element. For debt with a maturity of less than 15 years, the six-month average CIRR will be used. To both the ten-year and six-month averages, the same margins for differing repayment periods as those used by the OECD would continue to be added ( 0.75 percent for repayment periods of less than 15 years, 1 percent for 15 to 19 years, 1.15 percent for 20 to 29 years, and 1.25 percent for 30 years or more). Loans provided by a private entity will not be considered concessional unless accompanied by a grant or grant

\footnotetext{
29 (a) For the purpose of this guideline, the term "debt" will be understood to mean a current, i.e., not contingent, liability, created under a contractual arrangement through the provision of value in the form of assets (including currency) or services, and which requires the obligor to make one or more payments in the form of assets (including currency) or services, at some future point(s) in time; these payments will discharge the principal and/or interest liabilities incurred under the contract. Debts can take a number of forms, the primary ones being as follows: (i) loans, i.e., advances of money to the obligor by the lender made on the basis of an undertaking that the obligor will repay the funds in the future (including deposits, bonds, debentures, commercial loans and buyers' credits) and temporary exchanges of assets that are equivalent to fully collateralized loans under which the obligor is required to repay the funds, and usually pay interest, by repurchasing the collateral from the buyer in the future (such as repurchase agreements and official swap arrangements); (ii) suppliers' credits, i.e., contracts where the supplier permits the obligor to defer payments until some time after the date on which the goods are delivered or services are provided; and (iii) leases, i.e., arrangements under which property is provided which the lessee has the right to use for one or more specified period(s) of time that are usually shorter than the total expected service life of the property, while the lessor retains the title to the property. For the purpose of the guideline, the debt is the present value (at the inception of the lease) of all lease payments expected to be made during the period of the agreement excluding those payments that cover the operation, repair or maintenance of the property, and 9 (b) Under the definition of debt set out in point 9 (a) above, arrears, penalties, and judicially awarded damages arising from the failure to make payment under a contractual obligation that constitutes debt are debt. Failure to make payment on an obligation that is not considered debt under this definition will not give rise to debt.
} 
element provided by a foreign official entity, such as both components constitute an integrated financing package with a combined grant element equal to at least 35 percent.

\section{F. Adjustors to the Program Targets}

30. Program's quantitative targets are subject to the following adjustors:

\section{Overall fiscal deficit of the government}

31. The deficit ceilings for 2010-11 will be adjusted for excesses and shortfalls in loans and grants as defined below, relative to the program assumptions in the table below. The fiscal deficit will be adjusted:

(i) Upward (or downward) for the full amount of any excess (or shortfall) in project loans. Thus, foreign-financed investment projects, which are not under the short-term control of the government, would be unconstrained, varying in line with project loan financing. ${ }^{3}$

(ii) Downward by 50 percent of any shortfall in program loans ${ }^{4}$ of $\mathrm{GH} \notin 150$ million or less, and downward by the full amount of any shortfall beyond this amount. Thus, for shortfalls of up to GHф150 million in external loans, the government would have the option of balancing cuts in expenditures with resort to additional domestic financing. The possible resort to additional domestic financing from this adjuster is effectively capped at GHф75 million, limiting potential crowding-out of private sector credit;

(iii) Upward by 50 percent of any shortfall in program grants of GHф150 million or less, with no adjustment for any shortfall beyond this amount. As with adjuster (ii), this gives the option of balancing cuts in spending with additional resort to domestic financing. The latter is capped, again, at GH $\notin 75$ million; ${ }^{5}$

(iv) Downward by the full amount of any excess of program grants, less any use of program grants to repay outstanding domestic arrears at a more rapid pace than programmed; and

\footnotetext{
${ }^{3}$ No adjuster is needed for project grants, as shortfalls/excesses in project grants are precisely offset by shortfalls/excesses in foreign-financed capital spending, leaving the fiscal deficit unaffected.

${ }^{4}$ Program grants and loans are also referred to as budget grants and loans.

${ }^{5}$ The combined scope for additional domestic financing from adjusters (ii) and (iii) is thus GHф150 million.
} 
(v) Upward for the full amount of any excess in program loans, where these are used to repay outstanding domestic arrears at a more rapid pace than programmed. ${ }^{6}$

Budget Financing Assumptions, 2010-11

( $\mathrm{GH} \varnothing$ millions, cumulative from the start of the calendar year)

\begin{tabular}{|lccccc|}
\hline & 2010 & 2010 & 2010 & 2011 & 2011 \\
& Jun & Sep & Dec & Mar & Jun \\
\hline Program/budget grants & 195 & 289 & 298 & 82 & 192 \\
Program/budget loans & 289 & 579 & 579 & 4 & 98 \\
Project loans & 318 & 479 & 651 & 166 & 363 \\
\hline
\end{tabular}

\section{Net international reserves of the Bank of Ghana}

32. For the net international reserve (NIR) floors will be adjusted upward for any excess of budget grants and loans relative to the program baseline (see paragraph 27), except where this financing is used to repay outstanding domestic arrears at a more rapid pace than programmed.

\section{Net domestic financing of the government}

33. The ceiling on net domestic financing (NDF) will be adjusted upward by 50 percent of any shortfall in program loans and grants relative to the program (see paragraph 27), up to a maximum adjustment of GHф75 million for shortfalls in each of program loans and grants (and a maximum combined adjustment of GH $\notin 150$ million). For higher than programmed loans and grants, the ceiling will be adjusted downward by the full amount, except where these loans or grants are used to repay outstanding domestic arrears at a more rapid pace than programmed.

\section{Consumer price inflation}

34. The consumer price index is expected to be boosted in 2010 by adjustments of electricity tariffs to bring the average tariff to cost recovery levels. The Bank of Ghana intends to accommodate the first-round impact of these relative price adjustments on headline inflation, but will resist any second-round pass-through. Accordingly, the inflation consultation mechanism will be adjusted upward for a 12-month period by an amount equal to the increases in the residential electricity tariff (but not for any subsequent adjustments in line with market prices), multiplied by the weight of household electricity consumption in the CPI (1.51 percent). The adjuster will be rounded to the nearest 0.1 percent.

\footnotetext{
${ }^{6}$ Adjusters (iv) and (v) ensure that higher than programmed budget support (grants or loans) are used to repay domestic expenditure arrears as a first priority.
} 


\section{F. Provision of Data to the Fund}

35. Data with respect to the variables subject to performance criteria and indicative targets will be provided to Fund staff on a monthly basis with a lag of no more than eight weeks (except for select data for which the reporting lag is explicitly specified in Table 1). The authorities will transmit promptly to Fund staff any data revisions. For any information (and data) that is (are) relevant for assessing performance against program objectives but is (are) not specifically defined in this memorandum, the authorities will consult with Fund staff. 
Table 1. Ghana: Data to be Reported to the IMF

Item

Fiscal data (to be provided by the MOFEP)

Central budget operations for revenues, expenditures and financing, including clearance of arrears.

Divestiture receipts received by the budget (in cedis and foreign exchange, net of divestiture transactions costs).

The stock of domestic payments arrears by sub-category (as defined in para. 9 of the MEFP)

Monetary data (to be provided by the BOG)

Net domestic assets and net international reserves of the BOG.

Detailed balance sheet of the monetary authorities.

Monetary survey detailing the consolidated balance sheet of commercial banks using the new BSD2 Report Form.

Summary position of government committed and uncommitted accounts at BOG, as well as total financing from BOG. Accompanying table showing composition of other receipts and other expenditure.

Composition of banking system and nonbanking system net claims on government.

Debt registry showing structure and holders of domestic government debt, at face value and at discount. Similar table showing holders of treasury bills for open market operations.

Balance of Payments (to be provided by the BOG)

Export and import data on value, volume, and unit values, by major categories and other major balance of payments variables.

Foreign exchange cash flow.

\section{Periodicity}

Monthly, within eight weeks of the end of each month.

Monthly, within six weeks of the end of each month.

Quarterly, within six weeks of the end of each quarter

Monthly, within two weeks of the end of each month.

Monthly, within four weeks of the end of each month.

Monthly, within six weeks of the end of each month.

Monthly, within four weeks of the end of each month.

Monthly, within four weeks of the end of each month.

Monthly, within four weeks of the end of each month.

Quarterly, with a maximum lag of two months.

Monthly, within four weeks of the end of the month. 


\section{Table 1. Ghana: Data to be Reported to the IMF (concluded)}

\section{External debt and foreign assistance data (to be provided by MOFEP)} Information on the concessionality of all new external loans contracted by the government or with a government guarantee.

For the coming quarter: (i) total debt service due by creditor, (ii) amount of HIPC Initiative relief on each transaction, and (iii) debt service paid and the transfers to the HIPC Initiative account by creditor for the previous month. Report should cover government and government-guaranteed debt (as defined in this document).

External debt and external debt service incurred by enterprises with government ownership above 50 percent, even if loans have not been explicitly guaranteed by the government.

Short-term liabilities to nonresidents (maturity in one year or less), including overdraft positions and debt owed or guaranteed by the government or the BoG. Data on the BoG short-term liabilities to nonresident commercial banks on accounts 1201 plus 301 plus Crown Agent).

Disbursements of grants and loans by creditor

Other data (to be provided by GSS)

Overall consumer price index.

National accounts by sector of production, in nominal and real terms.

Electricity pricing (to be provided by the Ministry of Energy) Data on the tariff structure and the cost of producing electricity.

Petroleum pricing (to be provided by the Ministry of Energy)

(i) a breakdown of costs, including the ex-refinery price, duties, levies, and margins, for each of the individual petroleum products; and

(ii) the indicative maximum price approved in the bi-weekly review of petroleum pricing for each of the individual petroleum products.
Quarterly, within four weeks of the end of each quarter.

Quarterly within four weeks of the end of each quarter.

Quarterly, within three weeks of the end of each quarter.

Quarterly, within three weeks of the end of each quarter.

Quarterly, within four weeks of the end of each quarter.

Monthly, within two weeks of the end of each month.

Annual, within three months of the end of each year (switching to quarterly when they become available).

Quarterly, within four weeks of the end of each quarter.

Bi-weekly, within two days of the completion of the pricing review. 


\section{APPENDIX II-UPDATED DEBT SUSTAINABILITY ANALYSIS ${ }^{1}$}

Ghana's risk of debt distress is assessed to remain moderate, which is in line with the 2009 debt sustainability analysis (DSA). Public sector debt dynamics are broadly sustainable in light of the scale and evolution of the domestic debt stock, but suggest that even a stronger fiscal effort might be desirable than suggested in the baseline. However, the external and public DSAs suggest that vulnerabilities have increased compared to the previous DSA, reflecting the projected higher and more front-loaded nonconcessional borrowing. A low growth outcome associated with high investments substantially increases the risks to public debt sustainability.

\section{BACKGROUND}

1. The 2009 debt sustainability analysis pointed to improvements relative to the previous year in the debt sustainability baseline while also highlighting short- and medium-term vulnerabilities. Despite the favorable baseline trend, risk of debt distress was considered to be moderate. The risks to the baseline scenario were concentrated on the government's ability to sustain fiscal consolidation over the medium-to-long term and to successfully increase the growth potential of the nonoil sector through investing oil and gas revenues in a productive matter. A moderately higher recourse to external nonconcessional borrowing by the public sector over the medium term, reflecting Ghana's emerging middleincome status, was viewed as sustainable.

2. The public debt burden at end-2009 was below the level projected in the 2009 DSA (Text Table 1). Outstanding public debt and total external debt was 10 percentage points below the projection in last year's DSA, reflecting a confluence of factors. First, the cedi exchange rate strengthened against the U.S. dollar from mid-2009, ending the year at a more appreciated level than projected in the 2009 DSA. This exchange rate outcome reduced the public debt-to- GDP ratio in 2009 by more than 4 percentage points of GDP relative to the 2009 DSA projection. Second, loans from the World Bank ( $\$ 150$ million) and from the IMF under the ECF arrangement (\$100 million) anticipated in the 2009 DSA to be disbursed at end-2009 are now projected to be disbursed in mid-2010 (these combined loans were equivalent to 1.6 percent of 2009 GDP). Third, there was less commercial borrowing than anticipated in 2009, see Text Table 2, consistent with the much smaller current account deficit than earlier projected.

\footnotetext{
${ }^{1}$ This is an update to last year's DSA (IMF Country Report No. 09/256) that was included in the original ECF (PRGF) program request for Ghana.
} 
Text Table 1: Revised Public Debt Situation

\begin{tabular}{|c|c|c|c|c|c|c|}
\hline & \multicolumn{3}{|c|}{2009 DSA } & \multicolumn{3}{|c|}{2010 DSA } \\
\hline & 2008 & 2009 & 2010 & 2008 & 2009 & 2010 \\
\hline & Est. & Proj. & Proj. & Act. & Est. & Proj. \\
\hline & \multicolumn{6}{|c|}{ (in percent of GDP) } \\
\hline External debt ${ }^{1}$ & 42.8 & 57.2 & 63.4 & 41.0 & 47.1 & 51.3 \\
\hline Public debt & 58.2 & 70.0 & 72.6 & 57.6 & 60.4 & 68.4 \\
\hline
\end{tabular}

Sources: Ghanaian authorities and staff estimates and projections.

${ }^{1}$ Public and private sector external debt.

\section{MACroeconomic Assumptions FOR THE DSA}

\section{Compared to the 2009 DSA, macroeconomic assumptions have been modified}

to reflect more recent data (Text Table 2). While the 2009-10 output-inflation performance is less favorable, projections for the medium-to-long term are broadly unchanged. The latest staff estimates of real growth in 2009 are one percentage point below the previous projection and reflect the effects of the global financial crisis and tighter domestic policies, with a smaller shortfall in 2010. Inflation was about three percentage points higher than previously projected for 2009, with the gap narrowing to less than two percentage points for 2010. In 2009, the current account deficit also narrowed more than projected in the 2009 DSA, with a beneficial effect on external financing needs. While the cash-based primary fiscal balance in 2009 improved relative to the 2009 DSA, if measured on commitment-basis, the primary deficit was much higher because of the accumulation of new domestic payment arrears totaling 4.2 percent of GDP.

4. The current DSA assumes more front-loaded nonconcessional borrowing. This reflects the new framework on external debt limits for low-income countries, which would provide more flexibility in Ghana's nonconcessional external borrowing (Text Table 2). ${ }^{2}$ The more notable difference is for the period 2010-15, where the 2010 DSA assumes an increase in nonconcessional external borrowing to 4.5 percent of GDP on an annual average basis, up from a projected 2.4 percent of GDP in the $2009 \mathrm{DSA}^{3}$.

\footnotetext{
${ }^{2}$ Ghana was classified as a country with low debt vulnerabilities and low capacity. The low debt vulnerability was established based on the DSA (IMF Country Report No. 09/256), while the low capacity based on the PEFA and CPIA indices and after discussing the quality of macroeconomic public financial management institutions jointly by the Bank and the Fund.

${ }^{3}$ The projected new external nonconcessional borrowing has an average interest of 8 percent and average maturity of 8 years (with 2 years grace).
} 
Text Table 2: Key Macroeconomic Assumptions

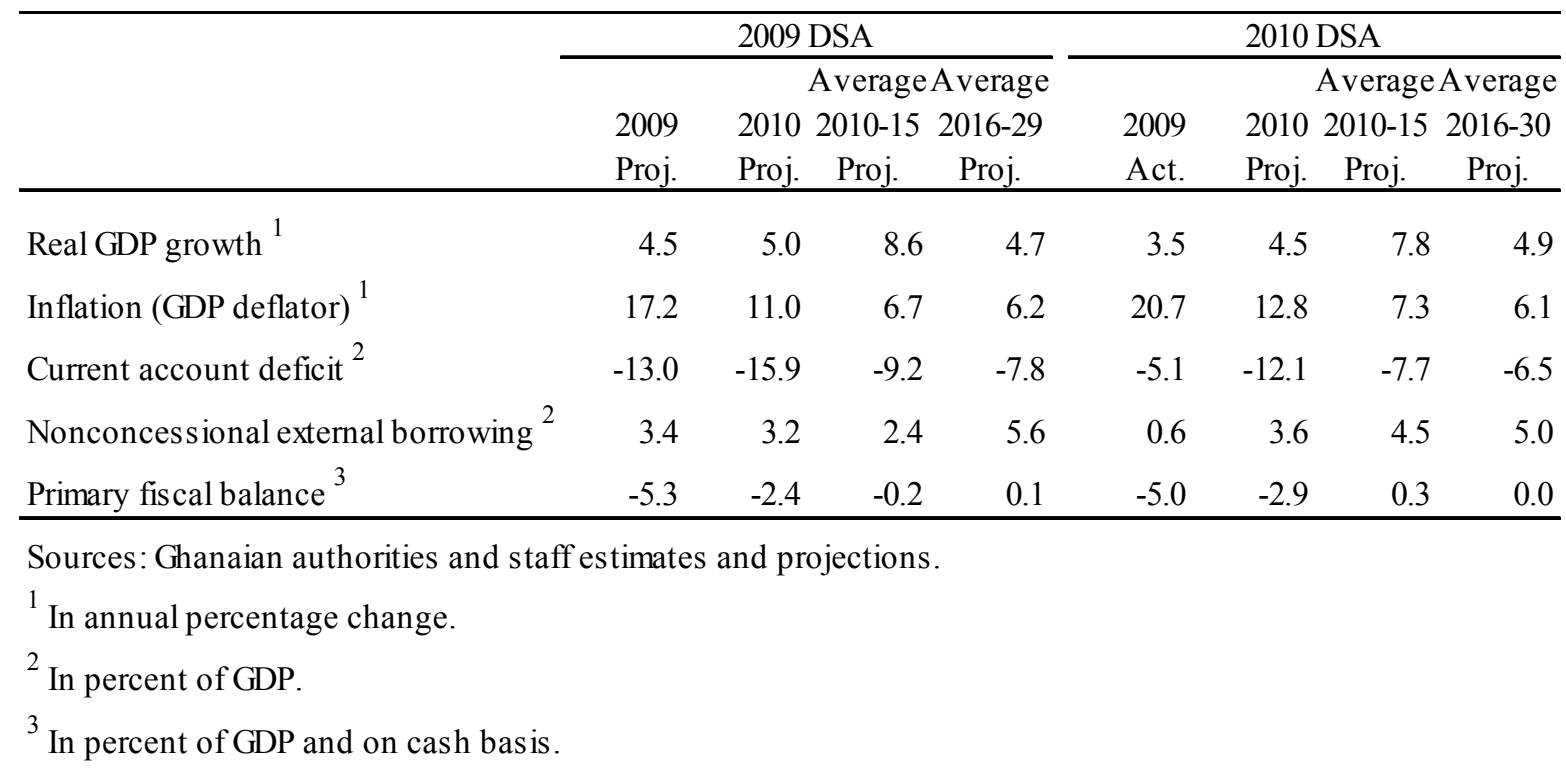

\section{EXTERNAL DSA}

\section{With the assumed level of external nonconcessional borrowing, risks of debt} distress have risen but appear manageable (Table 1). The external DSA shows that the thresholds on the present values of debt-to-GDP, debt-to-exports and debt-to-revenue ratios are not violated, though the baseline scenario gets close to the debt-to-GDP ratio threshold between 2014 and 2019. The thresholds on the debt service-to-exports and debt-service-torevenue ratios are not violated either, but the 2007 sovereign Euro bond redemption in 2017 is associated with a marked spike in debt service indicators.

\section{Standard stress tests underlie the importance of fiscal consolidation as Ghana} enters the oil era (Figure 1). Under an alternative scenario based on historical growth projections, debt burden indicators rise rapidly over the projection period, breaching most indicative thresholds. This, however, fails to account for the soon-to-begin oil production, and hence understates the long-term growth potential and overstates the fiscal financing needs. Under bound tests, ${ }^{4}$ the most extreme stress test points to breaches of some of the indicative thresholds. The stress tests underscore the risks related to potential delays in oil production.

\footnotetext{
${ }^{4}$ The standardized bound tests have been modified so that the shock influences years 2012-13, to account for the fact that real growth and exports are both projected to surge with the start of oil production in 2011 (20 and 37 percent, respectively). Using historic average growth rates minus one standard deviation therefore represent a dramatic revision to baseline projection for 2011 since this effectively eliminates the benefits of the oil sector from the DSA baseline without reducing imports financed by oil revenues.
} 


\section{Public Sector DSA}

7. Ghana's fiscal stance has a critical bearing on public debt sustainability in the projection period (Table 2). This highlights the importance of an early consolidation that would lead to much lower debt burden. The baseline scenario, which assumes a strong fiscal consolidation, also points to noticeable uncertainty related to the budget's capacity to service debt. Even under this strong fiscal adjustment, the debt service-to-revenue ratio is projected to stabilize around 35-40 percent over the medium term, after increasing in 2017 with the redemption of the 2007 Euro bond. A further risk to public debt sustainability arises from the recapitalization of two state-owned banks and from the external debt of the five SOEs (see MEFP 941 ) that will be included in the definition of public and publicly guaranteed external debt in the future.

8. Public debt dynamics are sensitive to growth and fiscal consolidation (Figure 2). The consequences of a delay in fiscal adjustment or a temporary shock to growth are well reflected in the bound tests. In both cases, the risks of debt distress become high.

9. A sustained low growth outcome would further increase the risks to public debt sustainability. This is illustrated by a scenario where high public investment fails to generate the sustained high long-term growth assumed in the baseline scenario. Under an alternative low growth scenario, ${ }^{5}$ a substantial fiscal deterioration over the medium- to longterm causes a rapid build-up of public debt. Risks of debt distress are higher than under the bound tests.

\section{Conclusions}

10. Vulnerabilities have increased compared to last year's exercise. The short-term trajectories have been influenced by the more pronounced economic slowdown and weaker fiscal adjustment effort during 2009-10. Over the medium to long term, the picture points to rising debt vulnerabilities (Text Tables 3 and 4). The vulnerabilities largely reflect the more front-loaded external borrowing at nonconcessional terms by the public sector assumed in the 2010 DSA exercise compared to the previous DSA, which has increased the debt levels and debt-service ratios in the medium-term. However, the debt vulnerability indicators stabilize in the long-run and continue to stay below their respective threshold levels in the baseline scenario, as in the 2009 DSA. Therefore, we maintain the assessment of moderate risk of debt distress. The analysis suggests that rapidly rising external borrowing at commercial terms would lead to increasing risks to debt sustainability. The public sector debt dynamics appear sustainable in light of the current size and the evolution of the

\footnotetext{
${ }^{5}$ In the low growth scenario, annual real growth during 2012-30 is lowered from the average of about 5 percent in the baseline scenario to 2.6 percent.
} 
domestic debt stock, but point to the need for strong fiscal consolidation. The baseline has increased, largely on account of increased external debt. Moreover, a weak growth response to higher investment has significant adverse implications for public debt sustainability.

Text Table 3: Indicators of External Debt Vulnerability (Baseline)

2015

2020

\begin{tabular}{lrr}
\hline PV of debt-to -GDP ratio & 29.5 & 30.7 \\
2009 DSA & 42.9 & 38.5 \\
2010 DSA & 50 & 50 \\
Threshold & & \\
\hline PV of debt-to-exports ratio & 51.0 & 60.0 \\
2009 DSA & 104.5 & 107.2 \\
2010 DSA & 200 & 200 \\
Threshold & & \\
\hline PV of debt-to-revenue ratio & 109.8 & 110.8 \\
2009 DSA & 150.6 & 144.5 \\
2010 DSA & 300 & 300 \\
Threshold & \multicolumn{3}{c}{} \\
\hline Debt service-to-exports ratio & 6.7 & 9.6 \\
2009 DSA & 10.1 & 17.8 \\
2010 DSA & 25 & 25 \\
Threshold & & \\
\hline Debt service-to-revenue ratio & 14.5 & 17.6 \\
2009 DSA & 14.5 & 24.0 \\
2010 DSA & 35 & 35 \\
Threshold & \multicolumn{2}{c}{} \\
\hline
\end{tabular}

Text Table 4: Indicators of Public Debt Vulnerability (Baseline)

$2015 \quad 2020$

PV of debt-to -GDP ratio

2009 DSA

$39.9 \quad 35.9$

2010 DSA

$60.3 \quad 48.6$

PV of debt-to-revenue ratio

2009 DSA

$133.3 \quad 121.5$

2010 DSA

$195.4 \quad 174.2$

Debt service-to-revenue ratio

2009 DSA

$20.8 \quad 24.6$

2010 DSA

22.0

33.8 
Table 1: External Debt Sustainability Framework, Baseline Scenario, 2007-30 1/ (In percent of GDP, unless otherwise indicated)

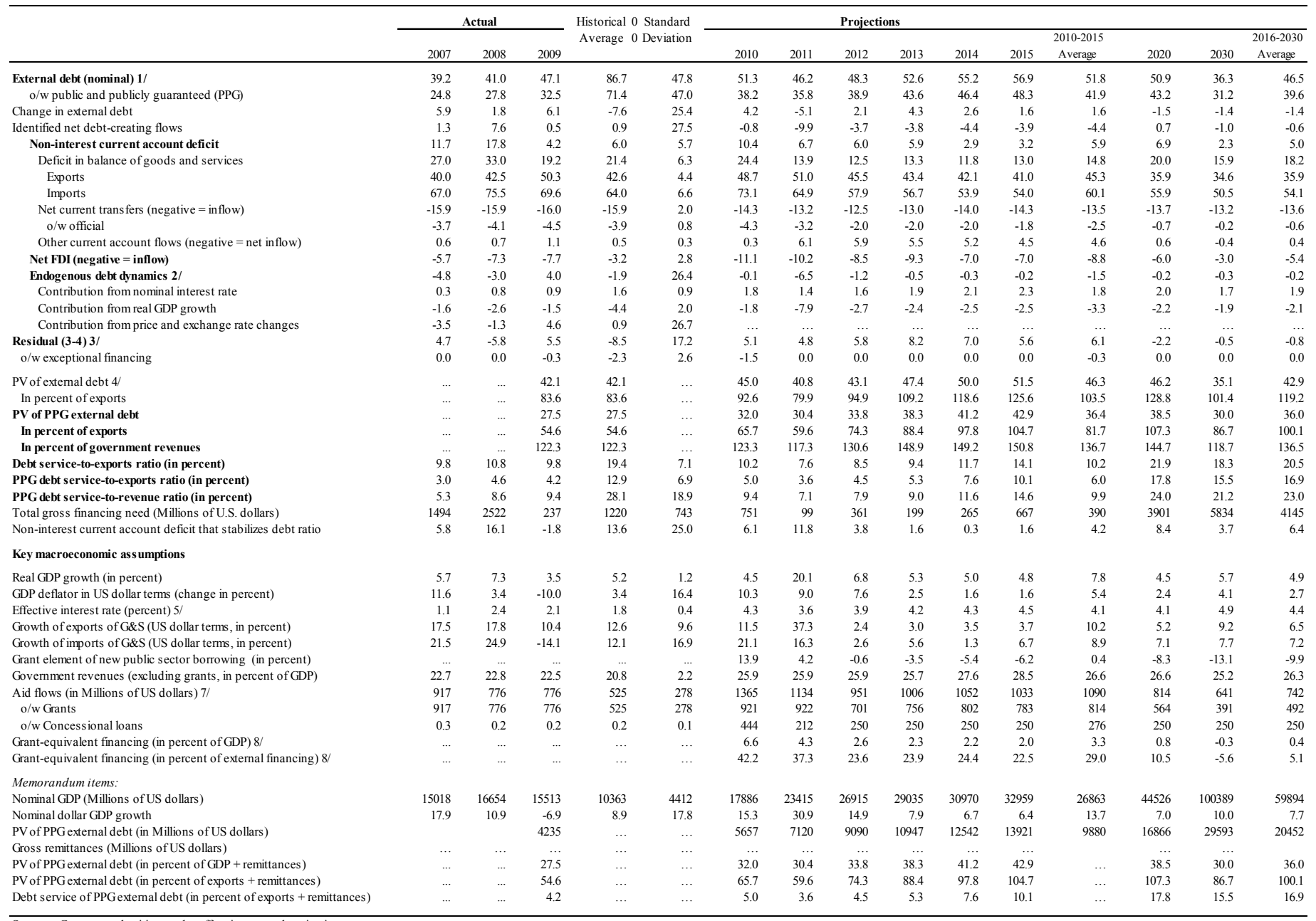

Sources: Country authories; and staffestimutes and proections.

1/ Includes both public and private sector external debt.

2/ Derived as $[\mathrm{r}-\mathrm{g}-\rho(1+\mathrm{g}) /(1+\mathrm{g}+\mathrm{\rho}+\mathrm{g})$ ) times previous period debt ratio, with $\mathrm{r}=$ nominal interest rate; $\mathrm{g}=$ real GDP growth rate, and $\rho=$ growth rate of GDP deflator in U.S. dollar terms

3/ Includes exceptional financing (i.e., changes in arrears and debt relief); changes in gross foreign assets; and valuation adjustments. For projections also includes contribution from price and exchange rate changes. 4/ Assumes that PV of private sector debt is equivalent to its face value.

G Historienta a

8/ Grant-equivalent financing includes grants provided directly to the government and through new borrowing (difference between the face value and the PV of new debt). 
Figure 1: Indicators of Public and Publicly Guaranteed External Debt under Alternatives Scenarios, 2010-30 1/

a. Debt Accumulation

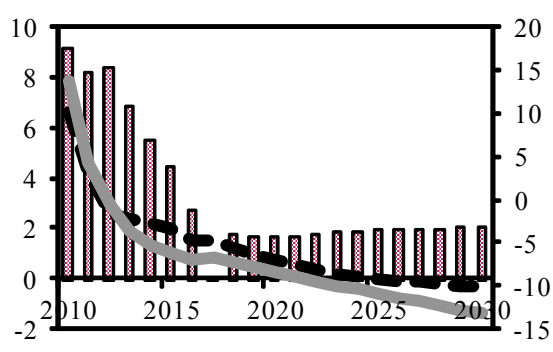

Rate of Debt Accumulation

Grant-equivalent financing (\% of GDP)

Grant element of new borrowing (\% right scale)

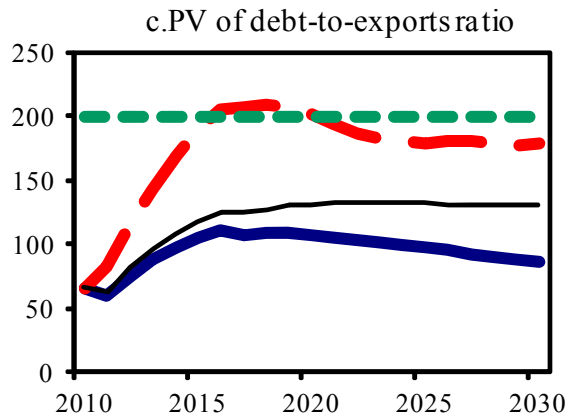

e.Debt service-to-exports ratio

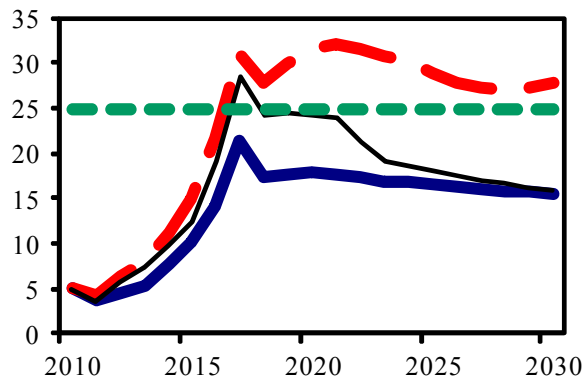

b.PV of debt-to GDP ratio

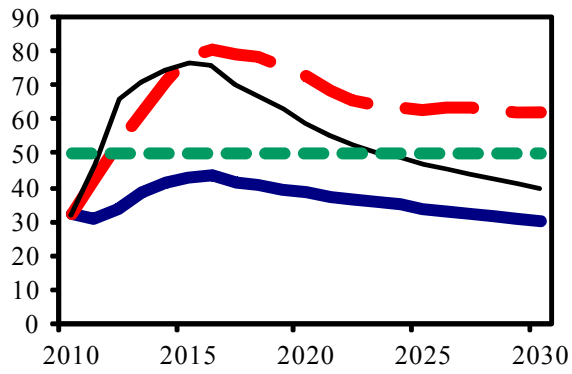

of debt-to-revenue ratio

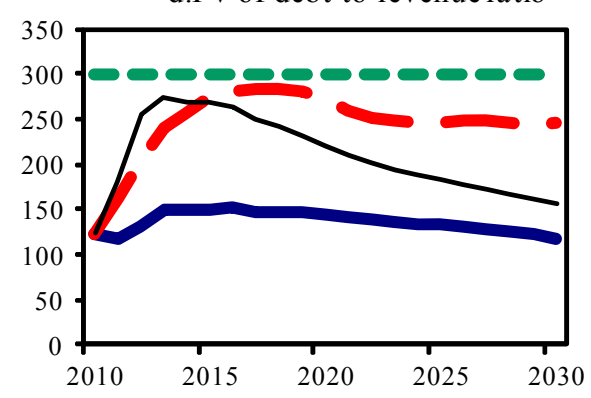

f.Debt service-to-revenue ratio

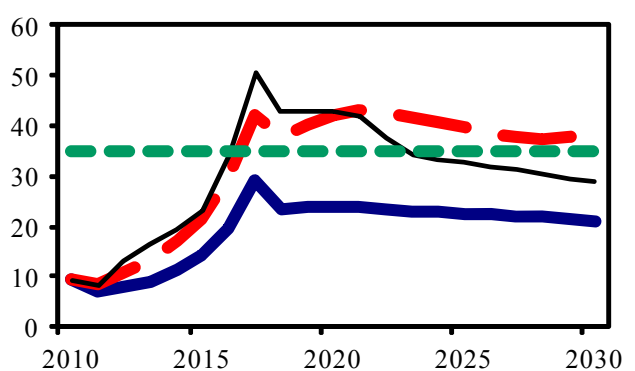

Sources: Country authorities; and staff estimates and projections.

$1 /$ The most extreme stress test is the test that yields the highest ratio in 2020. In figure $b$. it corresponds to a Combination shock; in c. to a Terms shock; in d. to a Combination shock; in e. to a Non-debt flows shock and in figure f. to a Combination shock 
Table 2: Public Sector Debt Sustainability Framework, Baseline Scenario, 2007-30 (In percent of GDP, unless otherwise indicated)

\begin{tabular}{|c|c|c|c|c|c|c|c|c|c|c|c|c|c|c|c|}
\hline & \multicolumn{3}{|c|}{ Actual } & \multirow[b]{2}{*}{ Average } & \multirow[b]{2}{*}{$\begin{array}{c}\text { Standard } \\
\text { Deviation }\end{array}$} & \multicolumn{5}{|l|}{ Estimate } & \multicolumn{5}{|c|}{ Projections } \\
\hline & 2007 & 2008 & 2009 & & & 2010 & 2011 & 2012 & 2013 & 2014 & 2015 & $\begin{array}{l}2010-15 \\
\text { Average }\end{array}$ & 2020 & 2030 & $\begin{array}{l}2016-30 \\
\text { Average } \\
\end{array}$ \\
\hline Public sector debt 1/ & 51.2 & 57.6 & 60.2 & 96.2 & 46.8 & 68.2 & 61.1 & 63.2 & 67.4 & 67.3 & 65.7 & 65.5 & 53.3 & 43.0 & 50.2 \\
\hline $\mathrm{o} / \mathrm{w}$ foreign-currency denominated & 24.8 & 27.8 & 32.5 & 71.4 & 47.0 & 38.2 & 35.8 & 38.9 & 43.6 & 46.4 & 48.3 & 41.9 & 43.2 & 31.2 & 39.6 \\
\hline Change in public sector debt & 9.1 & 6.4 & 2.6 & -8.2 & 23.9 & 8.0 & -7.1 & 2.1 & 4.2 & 0.0 & -1.7 & 0.9 & -1.6 & 0.0 & -1.5 \\
\hline Identified debt-creating flows & 0.8 & 2.8 & 1.5 & -3.9 & 26.5 & 1.5 & -12.3 & -4.4 & -0.5 & -3.6 & -3.9 & -3.9 & -1.2 & -0.7 & -1.4 \\
\hline Primary deficit & 6.1 & 10.7 & 5.0 & 3.2 & 3.4 & 2.9 & -0.1 & -0.2 & 0.3 & -2.2 & -2.8 & -0.3 & 0.1 & 1.2 & 0.0 \\
\hline Revenue and grants & 28.8 & 27.5 & 27.5 & 25.6 & 3.4 & 31.1 & 29.9 & 28.5 & 28.4 & 30.2 & 30.8 & 29.8 & 27.9 & 25.6 & 27.3 \\
\hline of which: grants & 6.1 & 4.7 & 5.0 & 4.9 & 1.6 & 5.1 & 3.9 & 2.6 & 2.6 & 2.6 & 2.4 & 3.2 & 1.3 & 0.4 & 1.0 \\
\hline Primary (noninterest) expenditure & 34.9 & 38.1 & 32.5 & 28.8 & 5.5 & 34.0 & 29.8 & 28.2 & 28.6 & 28.0 & 28.1 & 29.4 & 28.0 & 26.8 & 27.3 \\
\hline Automatic debt dynamics & -3.8 & -1.7 & -3.2 & -6.0 & 25.7 & -2.7 & -11.9 & -3.9 & -0.5 & -1.2 & -0.9 & -3.5 & -1.2 & -1.8 & -1.3 \\
\hline Contribution from interest rate/growth differential & -2.9 & -3.9 & -2.8 & -5.5 & 1.9 & 0.1 & -9.3 & -2.1 & -0.9 & -1.3 & -1.1 & -2.4 & -1.0 & -1.2 & -1.0 \\
\hline of which: contribution from average real interest rate & -0.7 & -0.5 & -0.9 & -0.6 & 0.6 & 2.7 & 2.1 & 1.8 & 2.3 & 1.9 & 2.0 & 2.1 & 1.4 & 1.1 & 1.4 \\
\hline of which: contribution from real GDP growth & -2.3 & -3.5 & -2.0 & -4.9 & 1.9 & -2.6 & -11.4 & -3.9 & -3.2 & -3.2 & -3.1 & -4.6 & -2.4 & -2.3 & -2.4 \\
\hline Contribution from real exchange rate depreciation & -0.8 & 2.2 & -0.4 & -0.5 & 25.2 & -2.7 & -2.6 & -1.8 & 0.4 & 0.1 & 0.2 & -1.1 & $\ldots$ & $\ldots$ & -0.1 \\
\hline Other identified debt-creating flows & -1.5 & -6.1 & -0.3 & -1.1 & 1.9 & 1.2 & -0.3 & -0.3 & -0.3 & -0.2 & -0.2 & 0.0 & -0.1 & 0.0 & -0.1 \\
\hline Privatization receipts (negative) & -0.8 & -5.7 & 0.0 & -0.7 & 1.8 & 1.7 & 0.0 & 0.0 & 0.0 & 0.0 & 0.0 & 0.3 & 0.0 & 0.0 & 0.0 \\
\hline Recognition of implicit or contingent liabilities & 0.0 & 0.0 & 0.0 & 0.0 & 0.0 & 0.0 & 0.0 & 0.0 & 0.0 & 0.0 & 0.0 & 0.0 & 0.0 & 0.0 & 0.0 \\
\hline Debt relief(HIPC and other) & -0.7 & -0.4 & -0.3 & -0.5 & 0.5 & -0.5 & -0.3 & -0.3 & -0.3 & -0.2 & -0.2 & -0.3 & -0.1 & 0.0 & -0.1 \\
\hline Other (specify, e.g. bank recapitalization) & 0.0 & 0.0 & 0.0 & 0.0 & 0.0 & 0.0 & 0.0 & 0.0 & 0.0 & 0.0 & 0.0 & 0.0 & 0.0 & 0.0 & 0.0 \\
\hline Residual, including asset changes & 8.3 & 3.6 & 1.1 & -4.3 & 13.3 & 6.5 & 5.2 & 6.5 & 4.7 & 3.5 & 2.2 & 4.8 & -0.4 & 0.7 & -0.2 \\
\hline \multicolumn{16}{|l|}{ Other Sustainability Indicators } \\
\hline PV of public sector debt & 26.4 & 29.7 & 55.2 & 27.7 & 11.1 & 62.0 & 55.6 & 58.0 & 62.1 & 62.1 & 60.3 & 60.0 & 48.6 & 41.8 & 46.6 \\
\hline $\mathrm{o} / \mathrm{w}$ foreign-currency denominated & 0.0 & 0.0 & 27.5 & 3.1 & 9.2 & 32.0 & 30.4 & 33.8 & 38.3 & 41.2 & 42.9 & 36.4 & 38.5 & 30.0 & 36.0 \\
\hline $\mathrm{o} / \mathrm{w}$ external & $\ldots$ & $\ldots$ & 27.5 & $\ldots$ & $\ldots$ & 32.0 & 30.4 & 33.8 & 38.3 & 41.2 & 42.9 & 36.4 & 38.5 & 30.0 & 36.0 \\
\hline PV of contingent liabilities (not included in public sector debt) & $\ldots$ & $\ldots$ & $\ldots$ & $\ldots$ & ... & $\ldots$ & $\ldots$ & $\ldots$ & ... & $\ldots$ & $\ldots{ }^{\prime}$ & $\ldots$ & $\ldots$ & $\ldots$ & r \\
\hline Gross financing need $2 /$ & 16.8 & 22.5 & 18.7 & 18.4 & 3.6 & 17.1 & 12.7 & 11.5 & 11.5 & 9.3 & 9.2 & 11.9 & 14.2 & 15.3 & 14.1 \\
\hline $\mathrm{PV}$ of public sector debt-to-revenue and grants ratio (in percent) & 91.5 & 108.3 & 200.8 & 95.9 & 52.4 & 199.4 & 186.3 & 203.8 & 219.1 & 205.6 & $195.6^{\prime \prime}$ & 201.6 & 174.4 & 163.0 & 170.5 \\
\hline $\mathrm{PV}$ of public sector debt-to-revenue ratio (in percent) & 116.0 & 130.4 & 245.5 & 118.5 & 62.8 & 239.0 & 214.6 & 224.3 & 241.2 & 224.9 & $211.9^{\prime}$ & 226.0 & 182.6 & 165.5 & 176.9 \\
\hline o/w external $3 /$ & & & 122.3 & 122.3 & & 123.3 & 117.3 & 130.6 & 148.9 & 149.2 & $150.8^{\prime}$ & 136.7 & 144.7 & 118.7 & 136.5 \\
\hline Debt service-to-revenue and grants ratio (in percent) $4 /$ & 19.3 & 24.0 & 28.1 & 42.6 & 22.0 & 26.9 & 23.6 & 21.8 & 20.2 & 20.1 & 22.0 & 22.4 & 33.8 & 38.3 & 35.0 \\
\hline Debt service-to-revenue ratio (in percent) $4 /$ & 24.5 & 28.9 & 34.4 & 51.9 & 24.7 & 32.2 & 27.2 & 24.0 & 22.2 & 22.0 & 23.8 & 25.2 & 35.4 & 38.9 & 36.2 \\
\hline Primary deficit that stabilizes the debt-to-GDP ratio & -3.1 & 4.3 & 2.4 & 1.2 & 3.8 & -5.1 & 7.0 & -2.3 & -3.9 & -2.1 & $-1.1 \%$ & -1.3 & 1.7 & 1.2 & 1.5 \\
\hline \multicolumn{16}{|l|}{ Key macroeconomic and fiscal assumptions } \\
\hline Real GDP growth (in percent) & 5.7 & 7.3 & 3.5 & 5.2 & 1.2 & 4.5 & 20.1 & 6.8 & 5.3 & 5.0 & 4.8 & 7.8 & 4.5 & 5.7 & 4.9 \\
\hline Average nominal interest rate on forex debt (in percent) & 2.1 & 3.8 & 3.3 & 2.2 & 0.7 & 6.2 & 4.8 & 5.0 & 5.2 & 5.2 & 5.3 & 5.3 & 4.9 & $5.7^{7}$ & 5.2 \\
\hline Average real interest rate on domestic debt (in percent) & -2.4 & $\begin{array}{r}-3.4 \\
-3.4\end{array}$ & -4.9 & -0.9 & 3.2 & 3.7 & 4.4 & 3.5 & 4.7 & 2.5 & $2.6^{\prime \prime}$ & 3.6 & 1.7 & $-0.1^{2}$ & 1.4 \\
\hline Real exchange rate depreciation (in percent, + indicates depreciation) & -5.1 & 9.3 & -1.4 & -0.4 & 22.8 & -8.3 & $\ldots$ & $\ldots$ & & $\ldots$ & & & & & \\
\hline Inflation rate (GDP deflator, in percent) & 13.9 & 16.9 & 20.7 & 20.7 & 7.5 & 12.8 & 9.0 & 7.6 & 4.2 & 5.0 & 5.0 & 7.3 & 5.8 & 7.6 & 6.1 \\
\hline Growth of real primary spending (deflated by GDP deflator, in percent) & 0.2 & 0.2 & -0.1 & 0.1 & 0.1 & 0.1 & 0.1 & 0.0 & 0.1 & 0.0 & 0.1 & 0.1 & 0.0 & 0.1 & 0.0 \\
\hline Grant element of new external borrowing (in percent) & $\ldots$ & $\ldots$ & $\ldots$ & $\ldots$ & & 13.9 & 4.2 & -0.6 & -3.5 & -5.4 & -6.2 & 0.4 & -8.3 & -13.1 & \\
\hline
\end{tabular}

ources. Country authorities, and staff est

1/ [ndicate coverage of public sector, e.g., general government or nonfinancial public sector. Also whether net or gross debt is used.]

2/ Gross financing need is defined as the primary deficit plus debt service plus the stock of short-term debt at the end of the last period.

3/ Revenues excluding grants.

$5 /$ Historical averages and standard deviations are generally derived over the past 10 years, subject to data availability 
Figure 2: Indicators of Public Debt Under Alternative Scenarios, 2010-30 1/
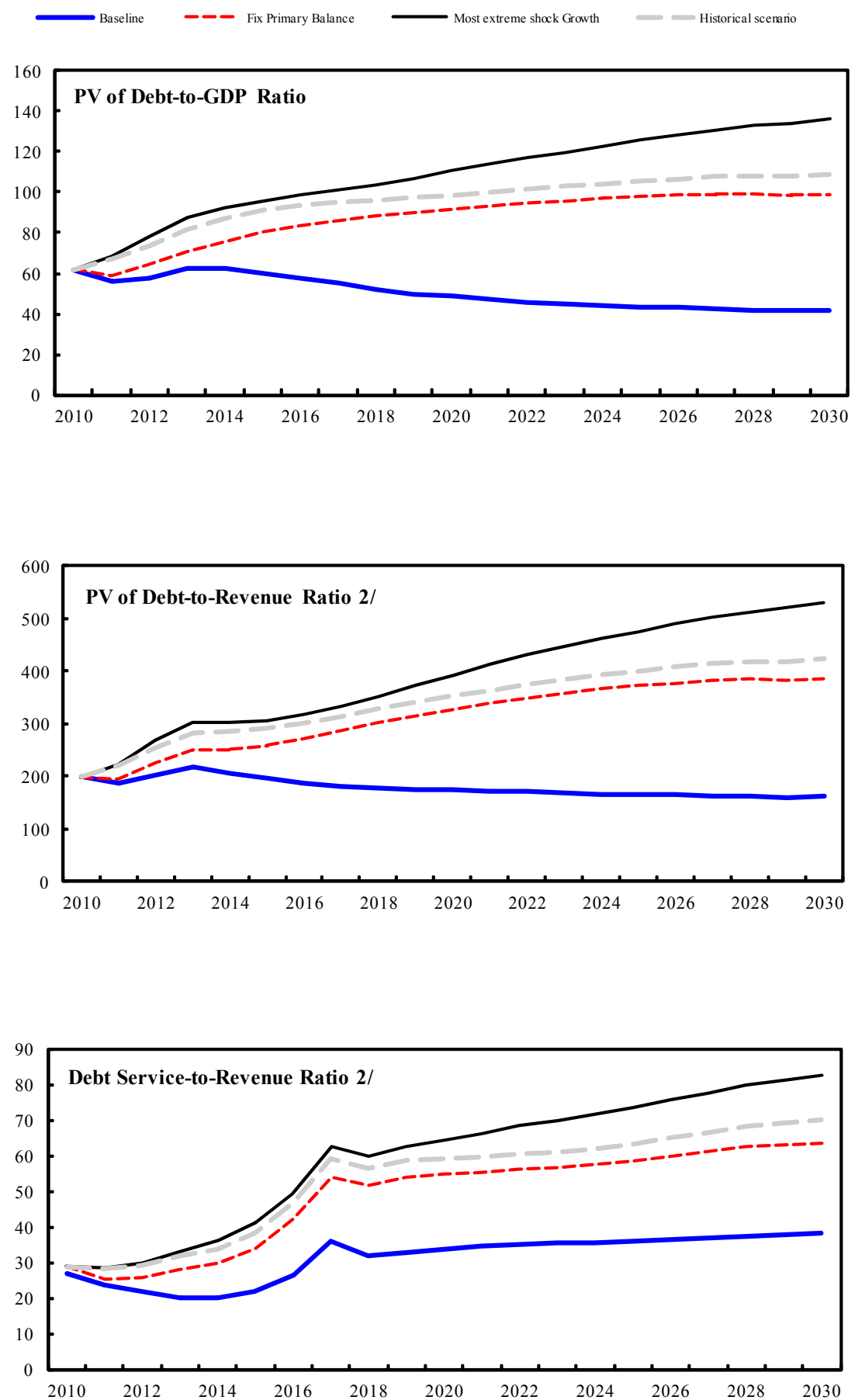

Sources: Country authorities; and staff estimates and projections.

$1 /$ The most extreme stress test is the test that yields the highest ratio in 2020.

$2 /$ Revenues are defined inclusive of grants. 


\title{
INTERNATIONAL MONETARY FUND
}

\author{
GHANA \\ Combined First and Second Reviews Under the Arrangement Under the Extended \\ Credit Facility, Request for Waiver of Nonobservance of Performance Criteria, \\ Modification of Performance Criteria and Rephrasing of Disbursements- \\ Supplementary Information and Supplement to the Letter of Intent
}

Prepared by the African Department

Approved by Michael Atingi-Ego and Dominique Desruelle

June 8, 2010

1. Since the staff report was issued, new information has become available on nonconcessional external borrowing. The Ghanaian authorities have informed staff that Ghana contracted a loan on November 25, 2009 with the ECOWAS Bank for Investment and Development (EBID) in an amount of $\$ 30$ million (0.2 percent of GDP) that breached the continuous performance criterion on nonconcessional external borrowing under the ECF arrangement. The loan has a grant element of 33 percent, just below the minimum 35 percent threshold under the Fund-supported program, and was regarded as important to finance a high return project to extend the electricity grid to eight districts in the Ashanti and Brong Ahafo regions.

2. The authorities are taking actions to correct this breach of the performance criterion. Specifically, they are negotiating with EBID an extension of the grace period under the loan beyond the current six years to make it concessional. In addition, as reflected in the new structural benchmarks in the ECF, the authorities are taking steps to strengthen debt management practices and project appraisal to safeguard against future breaches of the borrowing limit.

3. Staff supports the authorities' request for a waiver of nonobservance of the performance criterion on nonconcessional external borrowing on the basis of these corrective actions. 
June 7, 2010

Mr. Dominique Strauss-Kahn

Managing Director

International Monetary Fund

Washington, DC 20431

Dear Mr. Strauss-Kahn:

This updates our letter to you of May 13, 2010.

This is to inform you that Ghana contracted a loan on November 25, 2009 with the ECOWAS Bank for Investment and Development (EBID) in an amount of \$30 million that breached the continuous limit on nonconcessional external borrowing under our Fundsupported program (Tables 1 and 2 attached). The loan had a grant element of 33 percent, just below the minimum 35 percent threshold under the Fund-supported program, and was regarded as important to finance a high return project to extend the electricity grid to eight districts in the Ashanti and Brong Ahafo regions.

No funds have been disbursed under the loan to date, and we have requested that EBID amend the terms of the loan to bring the grant element above the minimum threshold of 35 percent under our Fund-supported program. EBID has indicated their willingness to revise the loan terms, and new terms consistent with a grant element of more than 35 percent are expected to be adopted by the end of June 2010 .

We regret this breach of the debt limit under our program, and are taking measures to strengthen debt management as outlined in our Memorandum of Economic and Financial Policies.

$/ \mathrm{s} /$

Dr. Kwabena Duffuor

Minister of Finance and

Economic Planning
$/ \mathrm{s} /$

Mr. K.B. Amissah-Arthur

Governor

Bank of Ghana 
Table 1. Ghana: Quantitative Program Targets (December 2008 - December 2009) ${ }^{1}$

(Cumulative from the beginning of calendar year, unless otherwise indicated)

\begin{tabular}{|c|c|c|c|c|c|c|c|c|c|c|c|c|}
\hline & & \multirow{3}{*}{$\begin{array}{l}2008 \\
\text { Dec. } \\
\text { Act. }\end{array}$} & \multicolumn{10}{|c|}{2009} \\
\hline & & & \multirow{2}{*}{$\begin{array}{l}\text { Mar. } \\
\text { Act. }\end{array}$} & \multirow{2}{*}{$\begin{array}{l}\text { Jun. } \\
\text { Act. }\end{array}$} & \multicolumn{4}{|c|}{ Sep. (MEFP, 7/09) } & \multicolumn{4}{|c|}{ Dec. (MEFP, 7/09) } \\
\hline & & & & & Prog. $^{2}$ & $\begin{array}{r}\text { Adjusted } \\
\text { Target } \\
\end{array}$ & Act. & $\begin{array}{r}\text { Met or } \\
\text { Not met }\end{array}$ & Prog. $^{2}$ & $\begin{array}{r}\text { Adjusted } \\
\text { Target } \\
\end{array}$ & Prel. & $\begin{array}{r}\text { Met or } \\
\text { Not met }\end{array}$ \\
\hline \multirow[t]{3}{*}{1} & Quantitative Performance Criteria & & & & & & & & & & & \\
\hline & Overall fiscal deficit of the government (ceiling; in millions of cedis) & 2,558 & 344 & 922 & 1,470 & 1,459 & 1,629 & Not met & 2,034 & 2,249 & 2,131 & Met \\
\hline & Net international reserves of the Bank of Ghana (floor; millions of U.S. dollars) ) $^{3}$ & 1,301 & -404 & -626 & -728 & -143 & -30 & Met & -404 & 49 & 1,159 & Met \\
\hline \multirow[t]{5}{*}{ II } & Continuous Performance Criteria (cumulative from July 15, 2009) & & & & & & & & & & & \\
\hline & Non-accumulation of external arrears (ceiling; millions of U.S. dollars) & 0 & 0 & 0 & 0 & 0 & 0 & Met & 0 & 0 & 0 & Met \\
\hline & Contracting or guaranteeing of new medium-to-long-term nonconcessional external debt (ceiling; US $\$$ millions) & $\ldots$ & $\ldots$ & $\ldots$ & 300 & 300 & 0 & & 300 & 300 & 130 & \\
\hline & Oil and gas sector & $\ldots$ & $\ldots$ & $\ldots$ & 300 & 300 & 0 & Met & 300 & 300 & 0 & Met \\
\hline & Other sectors & $\ldots$ & $\ldots$ & $\ldots$ & 0 & 0 & 0 & Met & 0 & 0 & 130 & Not met \\
\hline \multirow[t]{7}{*}{ III } & Inflation Consultation & & & & & & & & & & & \\
\hline & Twelve-month consumer price inflation (percent) & & & & & & & & & & & \\
\hline & Outer band (upper limit) & $\ldots$ & $\ldots$ & $\ldots$ & 19.5 & 19.5 & & & 17.6 & 17.6 & & \\
\hline & Inner band (upper limit) & 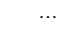 & & & 18.5 & 18.5 & & & 16.6 & 16.6 & & \\
\hline & Central target rate of inflation & 18.1 & 20.5 & 20.7 & 16.5 & 16.5 & 18.4 & Met & 14.6 & 14.6 & 16.0 & Met \\
\hline & Inner band (lower limit) & $\ldots$ & $\ldots$ & $\ldots$ & 14.5 & 14.5 & & & 12.6 & 12.6 & & \\
\hline & Outer band (lower limit) & $\ldots$ & $\ldots$ & $\ldots$ & 13.5 & 13.5 & & & 11.6 & 11.6 & & \\
\hline \multirow[t]{3}{*}{ IV } & Indicative Targets & & & & & & & & & & & \\
\hline & Net domestic financing of the government (ceiling, in millions of cedis) & 1,735 & 243 & 674 & 828 & 903 & 826 & Met & 1,033 & 1,108 & 1,042 & Met \\
\hline & Net domestic assets of the Bank of Ghana (ceiling; millions of cedis) ${ }^{4}$ & 64 & 331 & 698 & 990 & 990 & 462 & Met & 605 & 605 & -342 & Met \\
\hline
\end{tabular}

Sources: Ghanaian authorities, and IMF staff estimates and projections.

All variables and adjustors the targets are defined in the attached Technical Memorandum of Understanding (TMU).

Performance criterion.

Seplember and December 2009 targets after adjustment for SDR allocation.

The program ceiling has been adjusted to reflect the reclassification of SDR liabilities in the accounts of the Bank of Ghana as long-term foreign liabilities. 
Table 2. Ghana: Quantitative Program Targets (December 2009 - June 2011) ${ }^{1}$

(Cumulative from the beginning of calendar year, unless otherwise indicated)

2008

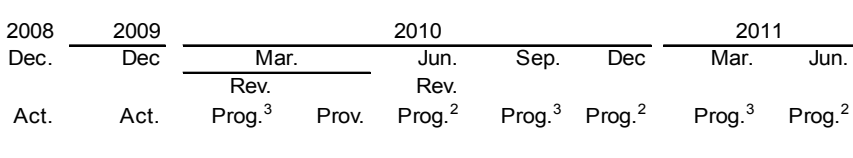

I Quantitative Performance Criteria

Overall fiscal deficit of the government (ceiling; in millions of cedis)

Net international reserves of the Bank of Ghana (floor; millions of U.S. dollars) ${ }^{4}$

Net change in the stock of domestic arrears (celing, in millions of cedis)

$\begin{array}{rrrrrrrrr}2,558 & 2,131 & 500 & \ldots & 1,186 & 1,958 & 2,077 & 444 & 746 \\ 1,301 & 2,459 & -83 & \ldots & -15 & -98 & 315 & 104 & 207 \\ & 1,429 & -28 & \ldots & -55 & -83 & -110 & -257 & -405\end{array}$

II Continuous Performance Criteria (cumulative from July 15, 2009)

Non-accumulation of external arrears (ceiling; millions of U.S. dollars)

Contracting or guaranteeing of new medium-to-long-term nonconcessional external debt (ceiling; US $\$$ millions)

Oil and gas sector 6

Fire-fighting equipment

Ada coastal protection project

Any sectors

0

0

0

$130.0 \quad 300.0$

$0.0 \quad 300.0$

0.0
0.0
0.0

III Inflation Consultation

Twelve-month consumer price inflation (percent)

Outer band (upper limit)
Inner band (upper limit)

Inner band (upper limit)
Central target rate of inflation

Inner band (lower limit)

IV Indicative Targets

Net domestic financing of the government (ceiling, in millions of cedis)

Net domestic assets of the Bank of Ghana (ceiling; millions of cedis) ${ }^{4}$

Poverty-reducing budget expenditures (floor; in millions of cedis)

$\begin{array}{rrrrrrrrr}\ldots & & 15.2 & \ldots & 12.7 & 12.5 & 12.5 & 12.0 & 12.0 \\ \ldots & & 14.2 & \ldots & 11.7 & 11.5 & 11.5 & 11.0 & 11.0 \\ 18.1 & 16.0 & 12.2 & 13.3 & 9.7 & 9.5 & 9.5 & 9.0 & 9.0 \\ \ldots & & 10.2 & \ldots & 7.7 & 7.5 & 7.5 & 7.0 & 7.0 \\ \ldots & & 9.2 & \ldots & 6.7 & 6.5 & 6.5 & 6.0 & 6.0 \\ & & & & & & & & \\ 1,735 & 1,022 & 875 & \ldots & 1,234 & 1,650 & 1,688 & 385 & 471 \\ -76 & -278 & -103 & -165 & -278 & -8 & 50 & -350 & -451 \\ 1,687 & 1,856 & 444 & \ldots & 820 & 1,463 & 2,106 & 554 & 1110\end{array}$

Sources: Ghanaian authorities, and IMF staff estimates and projections.

${ }^{1}$ All variables and adjustors the targets are defined in the attached Technical Memorandum of Understanding (TMU).

2 Performance criterion

${ }^{3}$ Indicative target.

${ }^{4}$ December 2009 target after adjustment for SDR allocation. March 2010 indicative ceiling from the original July 2009 ECF program.

${ }^{5}$ Cumulative from December 31, 2009. The end-of-period stock is GHc 1,429 million.

${ }^{6}$ For the GNPC to finance oil and gas exploration and production projects in Ghana and to acquire equity stakes in companies

undertaking oil and gas exploration and production in Ghana. 


\section{Statement by the IMF Staff Representative on Ghana June 9, 2010}

1. This statement provides information that has become available since the circulation of the staff report for the combined first and second reviews under the Extended Credit Facility Arrangement for Ghana (EBS/10/86). It does not alter the thrust of the staff appraisal.

2. Adjustments to electricity and water tariffs. On May 31, 2010, Ghana's Public Utility Regulatory Commission (PURC) announced increases in electricity and water tariffs, effective June 1, 2010, marking the first increase in both tariff schedules since November 2007. Electricity tariffs have been increased by between 21 and 42 percent for residential users and by 63 to 130 percent for non-residential users. The subsidized lifeline tariff for small residential users was left unchanged. The average electricity tariff, weighted by 2009 sales, increased by 58 percent, substantially exceeding the increase of 33 percent established as a prior action for the completion of the second ECF review. The PURC noted that, based on projected generating costs, these tariffs would broadly cover operating costs, while continuing budget support would be needed to finance new investments and plant refurbishment. Water tariffs have been increased by 21 to 32 percent for residential users, and by 40 to 64 percent for non-residential users. The PURC also announced that it is considering reintroducing an automatic formula for the periodic adjustment of tariffs.

3. Public sector salary adjustments. Negotiations for salary increases in 2010 concluded in May with agreement on a cost-of-living increase of 10 percent for all public workers, retroactive to the beginning of 2010. The salary increase is lower than the 17 percent assumed in the 2010 program projections, based on parity with the increase in minimum wages for 2010 . The savings from the smaller-than-programmed salary adjustment is estimated at up to 0.7 percent of GDP. Net savings will likely be smaller than this, however, as some low-income public sector workers will receive wage increases of more than 10 percent to avoid their salaries falling below the minimum wage, and some workers will receive upward salary adjustments as a result of the move to a single spine pay structure for the public service starting in 2010.

4. Net international reserves. Provisional end-March 2010 data show that net international reserves of the Bank of Ghana rose $\$ 155$ million between end-December 2009 and end-March 2010, to a level \$238 million above the unadjusted program floor.

5. Financial sector developments. The interest rate spread on Ghana's sovereign 10-year bond (maturing 2017) widened from 274 basis points at end-April 2010 to 467 basis points on June 1, paralleling global movements in risk spreads. The cedi has remained broadly stable against the U.S. dollar since March 2010, and has appreciated almost 8 percent against the Euro between end-April and June 1. Domestic interest rates have fallen 50 to 100 basis points since April, reflecting falling inflation expectations and monetary easing. 


\section{INTERNATIONAL MONETARY FUND \\ EXTERNAL \\ RELATIONS \\ DEPARTMENT}

Press Release No. 10/235

International Monetary Fund

FOR IMMEDIATE RELEASE

Washington, D.C. 20431 USA

June 9, 2010

\section{IMF Executive Board Completes First and Second Reviews Under Ghana's ECF Arrangement and Approves US\$119 Million Disbursement}

The Executive Board of the International Monetary Fund (IMF) approved today the first and second reviews of Ghana's economic performance under the Extended Credit Facility (ECF) arrangement. The approval will enable Ghana to draw SDR 81.50 million (US\$119 million), bringing total disbursements under the arrangement to SDR149.15 million (US\$218 million).

In completing the reviews, the Board granted waivers for the nonobservance of the continuous quantitative performance criterion on the contracting or guaranteeing of nonconcessional external debt and the nonobservance of the September 30, 2009 quantitative performance criterion on the overall budget (fiscal) deficit.

The Board approved on July 152009 a three-year arrangement under the Poverty Reduction and Growth Facility (PRGF) for Ghana (see Press Release No. 09/465), which was converted into an ECF.

Following the discussion on Ghana's economic performance, Mr. Murilo Portugal, Deputy Managing Director and Acting Chair, made the following statement:

"The Ghanaian authorities have achieved progress in 2009 in reducing inflation and strengthening external performance. While the fiscal deficit was significantly reduced in 2009 , revenue shortfalls resulted in the accumulation of new domestic payment arrears.

"Reduction of the budget deficit to 8 percent of GDP in 2010 will require tight controls over spending, including public administration costs, and strengthening revenue mobilization. To safeguard against new domestic payments arrears, the government should stand ready to tighten fiscal policies promptly, if the need arises. 
“Looking to 2011-12, the fiscal space created by Ghana's move to oil producer status will initially be modest, given the need to further reduce the fiscal deficit to a sustainable level and to repay domestic expenditure arrears. It will be important to tailor spending plans to available resources. Equally, the leeway for additional nonconcessional external borrowing is limited, and further steps to strengthen debt management capacity are needed.

"Programs to strengthen public finance management and revenue administration have been launched. Determined implementation will be important for regaining control over the budget and for prudent use of Ghana's future oil resources. Transparency in managing oil revenues and related spending will be key.

"Steps are being taken to tackle the under-pricing of energy products, including through the recent significant increase in power tariffs and by repaying the accumulated bank debts of the oil refinery. Going forward, it will be important to adhere to the principle of cost recovery energy pricing to avoid new claims on the budget. Close oversight over the banking system also remains warranted," Mr. Portugal added. 


\section{Statement by Jafar Mojarrad, Executive Director for Ghana June 9, 2010}

1. Our Ghanaian authorities thank staff for the high quality engagement and the balanced report on the first and second reviews of the program supported by the Extended Credit Facility (ECF). Against the backdrop of the global economic crisis and the expansionary fiscal policy in the run up to the elections, the authorities have steadfastly implemented strong macroeconomic and structural policies aimed at stabilizing the economy and placing it on a path of long-term growth and durable poverty alleviation. Performance under the ECF has been satisfactory; all performance criteria for the first and second reviews were met, with the exception of the end-September 2009 criterion for the overall fiscal deficit and the continuous criterion on non-concessional external borrowing. Electricity tariffs were increased by 58 percent on average, well in excess of the program's prior action requirement, and water tariffs were also increased substantially as highlighted in the staff's statement. Progress was also made on the structural front. While two structural benchmarks for end-September 2009 were missed because of inadequate funding of TA or capacity, all benchmarks for end-December were met, some ahead of schedule. The authorities have taken measures to remedy the breached performance criteria and request their waiver and completion of the ECF reviews by the Board.

\section{Recent economic developments}

2. Reflecting strong commodity exports and the impact of good rains, and despite the global crisis and the policy tightening by the new government, real GDP growth in Ghana was twice the average in Sub-Saharan Africa. Inflation declined sharply from 20 percent in June 2009 to 11.7 percent in April 2010, due to tight macroeconomic policies and the ensuing currency appreciation. Strong export performance in 2009, coupled with a significant fall in imports, led to a much stronger-than-projected current account, which improved by the equivalent of $13 \frac{1}{2}$ percent of GDP over 2008, and a major turnaround in the overall balance of payments position to reach a record surplus. International reserves rose to nearly 3 months of import cover at the end of 2009, including from the SDR allocation, exceeding the program target.

3. The fiscal situation in 2009 was challenging, despite improved collection from direct taxes and nontax revenue, in light of the decline in trade-related tax revenue, lower-thanprojected grants, and larger-than-originally estimated arrears to domestic suppliers from 2008. Notwithstanding these adverse developments and higher expenditure on wages and interest, the primary deficit was cut in half compared to 2008, and the overall cash deficit was reduced by 5 percentage points of GDP, including the repayment of old arrears to the tune of 2.8 percent of GDP. Nonetheless, taking into account the accumulation of new payments arrears, the deficit target on a commitment basis was exceeded, even though it declined by almost one half compared to 2008. Overall, the level of outstanding arrears at 
end-2009 was $15 \%$ lower than projected under the program. The public debt-to-GDP ratio rose somewhat from 2008, but remained well below the program's projection.

4. Monetary policy was eased in recent months, as the Bank of Ghana (BoG) took advantage of the fast declining inflation to provide some support to the slowing economy. In the event, the policy rate was reduced progressively from a peak of 18.5 percent in November 2009 to 15 percent by April 2010. The financial sector was largely unscathed by the global crisis and remained well capitalized, liquid, and profitable. Losses in the state oil refinery and other energy sector SOEs, however, have led to a sharp increase in NPLs that continue to weigh on banks' balance sheets, in particular that of the large state-owned GCB. Moreover, the insolvency of a smaller state-owned development bank has required BoG intervention pending its restructuring for divestiture.

\section{Economic policies for 2010 and the medium term}

5. Economic growth is projected to increase in 2010 and over the medium-term, peaking in 2011 with the onset of oil production, while the non-oil sector growth will accelerate to reach $6 \%$ per year starting from 2012. Inflation is expected to continue its downward trend to mid-single digits, the current account deficit to stabilize at a sustainable level, the external-debt-to-GDP ratio to decline further, and reserves to continue to rise to the equivalent of 5 months of imports.

\section{Fiscal policy}

6. The authorities remain committed to fiscal sustainability as the pillar of their strategy of growth and macroeconomic stability. The fiscal deficit on a cash basis will be reduced to 8 percent of GDP in 2010 and further to 31/2 percent in 2012 in line with resource availability and debt sustainability. The adjustment of the deficit on a commitment basis will be larger and more front-loaded, consistent with plans to clear all existing arrears. The authorities are confident that effective implementation of the wide-ranging revenue and expenditure measures contemplated under their medium-term program, combined with the start of oil revenues, will help create the needed fiscal space for increased spending on development infrastructure and poverty reduction. The authorities will monitor fiscal developments closely, and stand ready to take additional measures, if needed, to ensure that their fiscal goals are achieved.

7. In 2010, revenue will be boosted by a number of tax changes as outlined in the MEFP and the staff report. Commitment expenditure is also being restrained, although the wage bill and interest payments will increase initially before declining, reflecting higher 2009 outcome and the move to a new unified public pay system for the former, and upward revision of the cost of debt in 2009 for the latter. As a result of the May negotiations on the salary increase, the adjustment in public salaries will be lower than the program projections by up to 0.7 percent of GDP, as indicated in the staff statement. Poverty spending will be protected and subsequently rise in 2011-12. A number of social safety net programs are in 
place to support the most vulnerable groups, including for school fees and feeding, as well as targeted fertilizer and power subsidies.

\section{Monetary policy and financial sector issues}

8. Price stability remains the primary objective of monetary policy under Ghana's inflation targeting regime. The BoG aims at reducing inflation progressively to 5 percent at end 2012, and will stand ready to tighten policy as needed to achieve its targets. The monetary policy communication strategy will be further reinforced to ensure better clarity and transparency. The BoG will maintain a flexible exchange rate policy; in case of stronger-than-envisaged BOP, it will allow some currency appreciation while also building more reserves.

9. Steps are being taken to further strengthen the financial sector and address emerging vulnerabilities. In this connection, the BoG is strengthening its risk-based supervision capacity, with technical assistance from Canada, and is encouraging enhanced risk management capacity of commercial banks. The banking sector will benefit from payment of domestic arrears and improved financial standing of SOEs. Furthermore, the authorities are examining options for clearing the stock of SOE debt to the banking sector with MCM technical assistance and World Bank-supported restructuring plans. They are also looking forward to the upcoming FSAP update to assist in this regard. The GCB, which is heavily exposed to the petroleum sector, is receiving close attention, drawing on Fund TA mission advice.

10. Recognizing the adverse effect of domestic arrears on the economy and the banking sector, the authorities have mapped out a clearance schedule, including through possible concessional financing in the initial phase of the process, until more robust revenue collection allows for full elimination of all arrears. They are also committed to prevent future arrears accumulation by addressing the vulnerabilities associated with financial distress of energy sector SOEs.

\section{Structural reforms}

11. Over the medium term, further progress will be made in tax policy and administration reforms and budget management. Among others, existing revenue agencies will be brought under a common management in the newly established Ghana Revenue Authority; higher VAT thresholds will be set in line with international best practices; companies of certain size and turnover will be covered by a large taxpayer office; and a new tax regime will be adopted for small businesses. Public sector and payroll management reforms remain a priority, including through employee audits, expanded computerization of payrolls of agencies that are recipient of government subsidies, and a survey of pay comparability. Moreover, cash management will be reinforced in the context of an updated Ghana Integrated Financial Management Information System (GIFMIS) and a phased implementation of the Treasury single account. 
12. The authorities will carry out their comprehensive financial restructuring and recovery plan for the electricity sector. The recently implemented increase in electricity tariffs is a major component of the plan, and will be supported by improved revenue collection by the electricity sector public utilities and restructuring of their balance sheets. Efforts will also be made to improve the financial condition of other SOEs operating in the energy sector, including through recapitalization as needed and strengthening their governance.

13. A framework for managing oil revenue is being established based on international best practice to ensure full transparency and accountability and high efficiency. Informed by wide public consultations, the framework provides for full reporting to Parliament and the public, stringent auditing, and a rules-based approach to allocating receipts to a future generations fund and a spending stabilization fund. The framework is backed by appropriate legislation to be passed by Parliament.

14. The authorities intend to submit their updated poverty reduction strategy for 2010-13 to Parliament by August 2010. Priorities under the Ghana Shared Growth Agenda (GSDA), which has benefited from broad consultations with key shareholders, include macroeconomic stability, enhanced private sector competitiveness, sectoral strategies, and improved transparency and governance. These strategies are tailored to benefit the poor.

\section{Debt sustainability}

15. Ghana's risk of debt distress remains moderate, according to staff analysis, even though debt vulnerabilities have increased compared to the previous DSA. The authorities are determined to take the necessary measures to safeguard long-term debt sustainability. To this end, they recognize the importance of maintaining a strong fiscal stance, reinforcing pro-growth policies, and strengthening debt management. Mobilizing external support will rely mainly on grants and concessional financing. New non-concessional borrowing will be contracted only for critical projects for which grants or concessional financing are not available and that comply with clearly established appraisal guidelines as agreed by the Cabinet.

\section{Conclusion}

16. The authorities reiterate their determination to further strengthen program implementation, including in the core area of fiscal management, and will take the necessary measures to achieve the goals of their program. They agree on the need to reinforce their communication strategy to better articulate the benefits of their policies and to carefully manage, in particular, expectations regarding utility prices and oil dividend. Finally, the authorities are grateful to management and the Board for their continued support of Ghana's ambitious adjustment and reform program. 